\title{
ALINE CARVALHO
}

\section{INTERLEUCINA 25 NA INTERFACE MATERNO-FETAL EM CAMUNDONGOS}

Dissertação apresentada ao Programa de Pós-Graduação em Biologia Celular e Tecidual do Instituto de Ciências Biomédicas da Universidade de São Paulo, para obtenção do Título de Mestre em Ciências. 


\section{ALINE CARVALHO}

\section{INTERLEUCINA 25 NA INTERFACE MATERNO-FETAL EM CAMUNDONGOS}

Dissertação apresentada ao Departamento de Biologia Celular e do Desenvolvimento do Instituto de Ciências Biomédicas da Universidade de São Paulo, para obtenção do Título de Mestre em Ciências.

Área de concentração: Biologia Celular e Tecidual

Orientadora: Profa. Dra. Estela Bevilacqua

Versão Original 


\section{CATALOGAÇÃO NA PUBLICAÇÃO (CIP) \\ Serviço de Biblioteca e informação Biomédica \\ do Instituto de Ciências Biomédicas da Universidade de São Paulo}

Ficha Catalográfica elaborada pelo(a) autor(a)

\section{Carvalho, Aline}

Interleucina 25 na Interface Materno-fetal em Camundongos / Aline Carvalho; orientador Bstela Maria Andrade Forell Bevilacqua. - Säo paulo, 2016.

$81 \mathrm{p}$.

Dissertaçăo (Nestrado) ) -. Universidade de săo paulo, Instituto de ciencias Bionédicas.

1. IL-25. 2. IL-17BR. 3. Citocinas. 4. Gegtaçăo. 5. Placenta. I. Andrade porell Bevilacqua, Bgtela Maris, orientador. II. Título. 
Candidato(a):

Título da Dissertação:

Orientador(a):
Aline Carvalho

Interleucina 25 na Interface Materno-Fetal em Camundongos

A Comissão Julgadora dos trabalhos de Defesa da Dissertação de Mestrado, em sessão pública realizada a ................................., considerou

( ) Aprovado(a) ( ) Reprovado(a)

Examinador(a): Assinatura:

Nome:

Instituição:

Examinador(a): Assinatura:

Nome:

Instituição:

Presidente: Assinatura:

Nome:

Instituição: 


\section{CertificAdo}

Certificamos que o protocolo registrado sob $n^{\circ} \mathbf{4 1}$ nas fls. 18 do livro 03 para uso de animais em experimentação, sob a responsabilidade do Prof(a) Dr(a) Esteia Bevilacqua, Coordenador (a) da Linha de pesquisa "Expressão da citocina IL-25 na interface materno-fetal durante a fase de implantação embrionária e possiveis funções nas células trofoblásticas" do qual participam o(s) aluno(s) Aline Carvalho, está de acordo com os Princípios Éticos de Experimentação Animal adotado pela Sociedade Brasileira de Ciência de Animais de Laboratório (SBCAL) e foi aprovado pela COMISSÃO DE ÉTICA NO USO DE ANIMAIS (CEUA) em 05.06.2014, com validade de 4 anos.

São Paulo, 09 de junho de 2014.
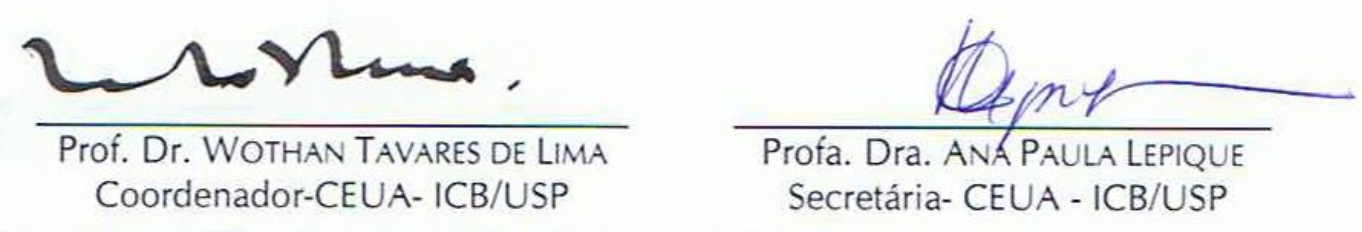
À Minha família, o alicerce da minha formação e o pilar dos meus valores. Ao Saulo, meu companheiro e porto-seguro. 


\section{AGRADECIMENTOS}

In memorian de meu pai, Luiz Antônio Carvalho, peça fundamental desta conquista, pois sempre destacou a importância do conhecimento e me incentivou na busca dos meus objetivos.

Á minha mãe Ada Martins da Silva Carvalho, por ser o conforto para os momentos difíceis, por toda a preocupação, orações e apoio.

Á minha irmã Karine Carvalho, por seu carinho, jeito doce e fraterno.

Aos meus avós Iracy e Adônias, exemplos de vida e fontes de amor incondicional.

Ao Saulo, meu amigo, namorado, noivo e marido. Companheiro em toda essa jornada, parceiro de vida.

Aos amigos que sempre estiveram presentes e partilharam das emoções, confissões e desabafos.

À minha orientadora Profa. Dra. Estela Bevilacqua, por ter me recebido em seu laboratório, dedicando seu tempo e partilhando do seu vasto conhecimento. Exemplo inspirador de paixão a ciência.

Aos colegas de laboratório: Aline Rodrigues Lorenzon, Caroline Borgato Guedes, Gabriela Daolio, Karen Matias do Prado, Karla Castro, Rodrigo Barbano Weingrill e Sara Maria Zago Gomes, por toda a ajuda e esforço que desprenderam para que esse trabalho se realizasse.

À Rosangela Augusto Farias, por sua dedicação ao laboratório e suporte aos alunos.

Às colaboradoras Carla Letícia Bandeira e Elaine Cardoso, que enriqueceram esse trabalho com seus conhecimentos e se dedicaram tanto por ele.

À Coordenadoria do Programa de Pós-Graduação em Biologia Celular e Tecidual, por todo trabalho e dedicação em pró aos alunos.

Aos funcionários do Instituto de Ciências Biomédicas, sempre solícitos e pré-dispostos.

Á CAPES, pelo apoio financeiro.

Á todos que estiveram, diretamente ou indiretamente envolvidos e não foram citados, mas que se importaram e influenciaram essa realização. 
"Ninguém poderá jamais aperfeiçoar-se, se não tiver o mundo como mestre. A experiência se adquire na prática. "

William Shakespeare 


\section{RESUMO}

CARVALHO, A. Interleucina 25 na Interface Materno-Fetal em Camundongos. 2016. 81 f. Dissertação (Mestrado em Biologia Celular e Tecidual) - Instituto de Ciências Biomédicas, Universidade de São Paulo, São Paulo, 2016.

Durante a gestação, a interação entre os organismos materno e embrionário é mediada por diversas moléculas reguladoras produzidas no ambiente uterino que são fundamentais para o estabelecimento de um ambiente tolerante ao feto. A expressão de mediadores inflamatórios também participa deste processo influenciando o ambiente uterino e a própria placenta. As citocinas, potentes mediadores celulares, regulam as respostas imunológicas, integrando a rede sinalizadora que controla a gestação. Desbalanço nos perfis de citocinas, sistêmica ou localmente no ambiente placentário tem sido descrito em distúrbios gestacionais culminando com perdas fetais. Evidências recentes mostraram que a expressão de uma nova citocina, a Interleucina 25, está alterada em pacientes que apresentam abortos recorrentes, sugerindo um papel imunorregulador nas funções reprodutivas. Neste contexto, torna-se interessante avaliar a expressão e distribuição da IL-25 na interface materno-fetal durante a gestação. Neste estudo objetivamos caracterizar a expressão de IL-25 e seu receptor IL-17BR em células placentárias e no sangue materno ao longo da gestação em camundongos. A análise da expressão gênica de IL-25 e IL-17BR por qRT-PCR foi realizada em sítios de implantação e em porções fetais e maternas de placentas nos dias 10,5, 13,5, 16,5 e 19,5 de gestação (dg). Células mononucleares do sangue (CMNs) materno e células placentárias isoladas foram utilizadas para ensaios de citometria de fluxo nestes mesmos períodos. A imunolocalização da citocina e do receptor foi avaliada em cortes histológicos. Nossos dados mostraram que a expressão gênica de IL-25 se intensifica após o período implantacional, aumentando os níveis de RNAm gradativamente a partir do dia 10,5 até 0 16,5 de gestação. A citocina e o receptor foram diferencialmente expressos nos compartimentos placentários. A análise da expressão protéica por citometria de fluxo confirmaram os dados de expressão gênica e a imunolocalização desses fatores. IL-25 e IL-17BR foram expressos em toda a interface materno-fetal, sendo a citocina mais prevalente na placenta fetal, enquanto que os níveis e expressão do receptor foram mais intensos na porção materna. Por citometria de fluxo foram também caracterizadas as populações celulares que poderiam contribuir para os níveis encontrados da citocina e receptor. Na placenta fetal, a presença de células trofoblásticas fenotipicamente caracterizadas pela expressão de citoqueratina (CK8), expressaram níveis mais altos de IL-25, enquanto que leucócitos locais (CD45+) e da região materna da placenta expressaram mais intensamente o receptor IL-17BR. A maior expressão de IL-25 pela porção fetal e de IL-17BR pela porção materna da placenta sugere uma ação local e uma interação parácrina entre trofoblasto e decídua. Além disso, o aumento de expressão principalmente de IL-17BR em leucócitos mononucleares maternos nas fases em que há aumento de expressão da IL-25 pela placenta corrobora a idéia de que esta citocina possa estar também participando da modulação destas células e consequentemente do sistema imunológico materno durante a gestação. No contexto imunológico, o momento gestacional em que a IL-25 é identificada nos compartimentos da interface materno-fetal, sugere que ela possa estar atuando na modulação da resposta imune local e materna, promovendo um ambiente tolerante para o desenvolvimento fetal.

Palavras-chave: IL-25. IL-17BR. Citocinas. Placenta. Gestação. 


\section{ABSTRACT}

CARVALHO, A. Interleukin 25 in Maternal-Fetal Interface in Mices. 2016. 81 p.

Dissertation (Masther thesis in Cell and Tissue Biology) - Instituto de Ciências

Biomédicas, Universidade de São Paulo, São Paulo, 2016.

During pregnancy, the interactions between the embryo and maternal organisms are mediated by different regulatory molecules produced at the maternal-fetal interface that is essential to the establishment of a tolerant environment to fetus development. The expression of a variety of inflammatory mediators participates in this interaction influencing the uterine environment and the placenta. Cytokines are potent cellular mediators that regulate the immune responses through a signaling network, also able to control pregnancy processes. Cytokine imbalance systemic or locally in the placental environment has been described in many pregnancy disorders and associated to fetal losses. Recent evidence showed that the expression of a novel cytokine, interleukin 25, is decreased in patients with recurrent abortions, suggesting immunoregulatory roles in reproductive functions. In this context, it is relevant to know the expression and distribution of IL-25 at the maternal-fetal interface throughout pregnancy. This study aimed to characterize the IL-25 expression and its receptor IL-17BR in the mouse placental cells and maternal blood during pregnancy. The analysis of IL-25 and IL-17BR gene expression was performed by qRT-PCR in implantation sites and fetal and maternal portions of the placenta on the days 10.5, 13.5, 16.5 and 19, 5 of gestation (dg). Peripheral blood mononuclear cell (PBMCs) and cells isolated from maternal and fetal placenta were used for flow cytometry analyses on the same days of gestation. The immunolocalization of the cytokine and receptor was evaluated in histological sections at different gestational days. Our data showed that IL-25 gene expression is intensified after the implantation period, increasing mRNA levels gradually from $10,5 \mathrm{dg}$ to $16,5 \mathrm{dg}$. Cytokine and receptor were differently expressed in the placental compartments. Analysis of protein expression by flow cytometry confirmed the gene expression data and reactivity observed in the immunohistochemistry reactions. IL-25 and IL-17BR were expressed throughout the maternal-fetal interface; the cytokine was prevalent in the fetal part of the placenta, while the receptor was mostly expressed on the maternal side. Among the cell populations that could most contribute to the cytokine/receptor levels, we identified trophoblast cells, phenotypically characterized as CK8+ cells, producing IL-25 at the fetal side of the placenta, and leukocytes (CD45 +) expressing the IL-17BR at the both, fetal and maternal side. Among the period studied, IL-25 and IL-17BR expression were higher at days 13.5 and $16.5 \mathrm{dg}$. The increased expression of IL-25 at the fetal side and IL-17BR at maternal side of the placenta suggests a local action and a paracrine interaction between trophoblast and uterine cells. Furthermore, increased expression mainly of IL-17BR in maternal mononuclear leukocytes in the phases in which there is also high expression levels of IL-25 by placenta cells supports the idea that this cytokine may also be participating in the modulation of these leukocytes and therefore of the maternal peripheral immune system during pregnancy. At the immunological point of view, the gestational period in which IL-25 is identified in the compartments of the maternal-fetal interface, suggests it may be acting in modulating the local and maternal immune response, promoting a tolerant environment for fetal development.

Palavras-chave: IL-25. IL-17BR. Cytokine. Placenta. Gestation. 


\section{LISTA DE FIGURAS}

Figura 1 - Representação esquemática da placenta de camundongo madura. 23

Figura 2 - Padrão de expressão gênica da Interleucina 25 em sítios de implantação..

Figura 3 - Expressão gênica da Interleucina 25 e do receptor IL-17A/B em placentas de camundongo. 46

Figura 4 - Imunolocalização da IL-25 na interface materno-fetal no dia 10,5 de gestação.

Figura 5 - Imunolocalização do receptor IL-17B na interface materno-fetal no dia 10,5 de gestação. (A-D)

Figura 6 - Imunolocalização da IL-25 e do receptor IL-17B na interface materno-fetal nos dias 13,5 (A-E) e 16,5 de gestação (F-H)..

Figura 7 - Imunolocalização da IL-25 e do receptor IL-17B na interface materno-fetal no dia 19,5 de gestação.

Figura 8 - Avaliação das populações de células isoladas da região fetal da placenta quanto a produção da citocina IL-25 (A) e seu ligante IL-17BR (B) nos dias 10,5, 13,5, 16,5 e 19,5 de gestação por citometria de fluxo. .52

Figura 9 - Avaliação da populações de células trofoblásticas citoqueratina positivas $(\mathrm{B}, \mathrm{CK}+)$ e leucocitária $(\mathrm{C}, \mathrm{CD} 45+)$ isoladas da região fetal da placenta quanto a produção da citocina IL-25 e seu ligante IL-17BR nos dias 10,5, 13,5, 16,5 e 19,5 de gestação por citometria de fluxo.

Figura 10 - Avaliação das populações de células isoladas da porção materna da placenta (decídua) quanto a produção da citocina IL-25 (A) e seu ligante IL-17BR (B) nos dias 10,5, 13,5, 16,5 e 19,5 de gestação, por citometria de fluxo.

Figura 11 - Avaliação das populações de células totais presentes na decidua (A) e de células leucocitárias $(B, C D 45+)$ isoladas da região materna da placenta quanto a produção da citocina IL-25 e seu ligante IL-17BR, nos dias 10,5, 13,5, 16,5 e 19,5 de gestação, por citometria de fluxo.

Figura 12 - Avaliação das populações de células totais isoladas da região materna (colunas vazadas) e fetal (colunas pretas) da placenta quanto a produção da citocina IL-25 (A) e seu ligante IL-17BR (B), nos dias 10,5, 13,5, 16,5 e 19,5 de gestação, por citometria de fluxo. 
Figura 13 - Avaliação da população de células mononucleares isoladas do sangue materno quanto a produção da citocina IL-25 (A) e seu ligante IL-17BR (B), nos dias 10,5, 13,5, 16,5 e 19,5 de gestação, por citometria de fluxo.

Figura 14 - Avaliação da produção da citocina IL-25 e seu ligante IL-17BR nos dias $10,5,13,5,16,5$ e 19,5 de gestação, nos diferentes compartimentos que integram a interface materno-fetal, por citometria de fluxo..

Figura 15 - Representação esquemática da participação de IL-25 e IL-17BR na placenta de camundongo.

Figura 16 - Análise por citometria de fluxo para IL-25 e IL-17BR na porção fetal da placenta:

Figura 17 - Expressão de IL-25 e seu receptor IL-17BR por células trofoblásticas e leucócitos na placenta fetal: $\mathrm{s}$.

Figura 18 - Análise por citometria de fluxo para IL-25 e IL-17BR na porção materna da placenta: .79

Figura 19 - Expressão de IL-25 e seu receptor IL-17BR por células leucocitárias na porção materna da placenta:

Figura 20 - Análise por citometria de fluxo para IL-25 e IL-17BR no sangue periférico materno: 


\section{LISTA DE TABELAS}

Tabela 1 - Lista da sequência de oligonucleotídeos para os genes estudados .40 


\section{SUMÁRIO}

1 INTRODUÇÃO

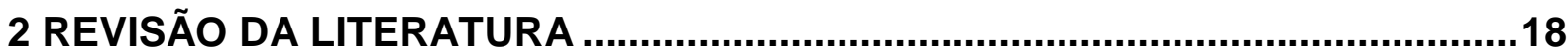

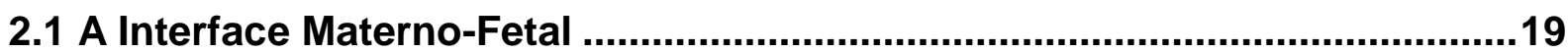

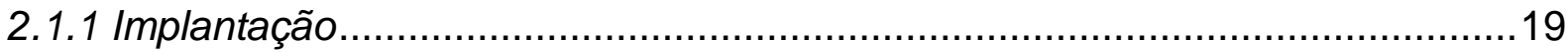

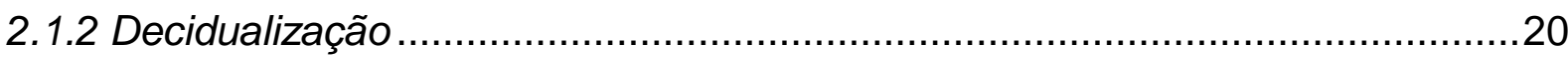

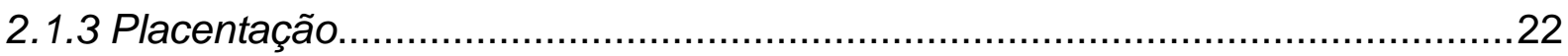

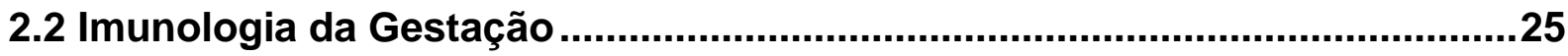

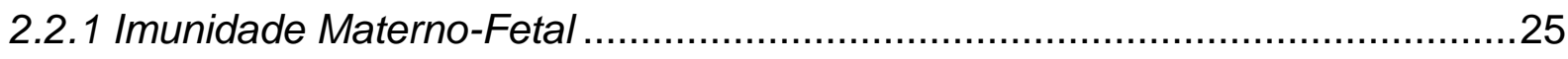

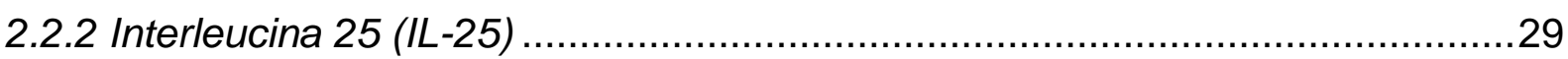

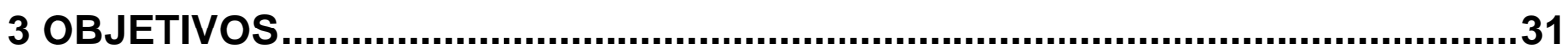

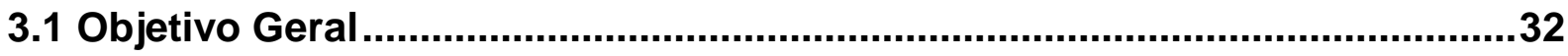

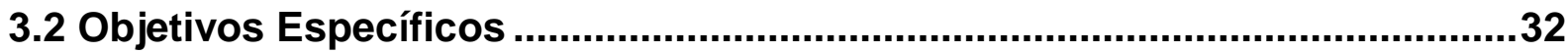

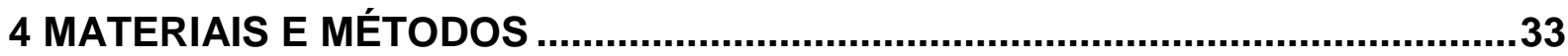

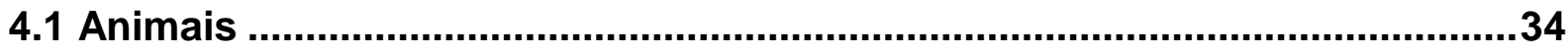

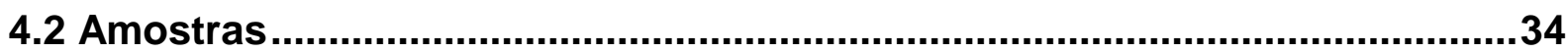

4.2.1 Obtenção dos Sítios de Implantação e Placentas...........................................34

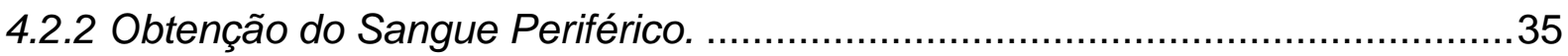

4.3 Níveis Protéicos de IL-25 e do Receptor IL-17BR nos Compartimentos da

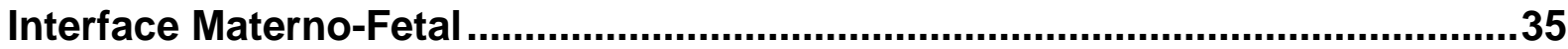

4.3.1 Isolamento das Células Trofoblásticas (Porção Fetal da Placenta). .................35

4.3.2 Isolamento das Células Deciduais (Porção Materna da Placenta).....................36

4.3.3 Isolamento de Células Mononucleares do Sangue (CMNs) .............................36

4.3.4 Criopreservação das Células Isoladas ..........................................................36

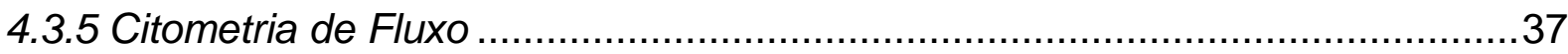

4.4Expressão Gênica da Citocina e seus Receptores em Sítios de Implantação e Placenta em Diferentes Dias de Gestação .........................................................38

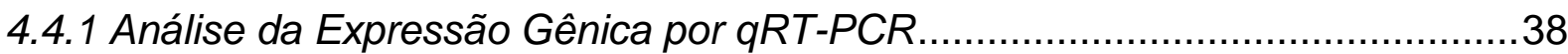

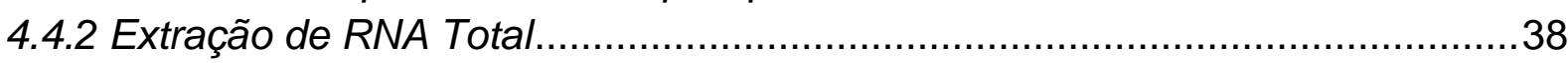

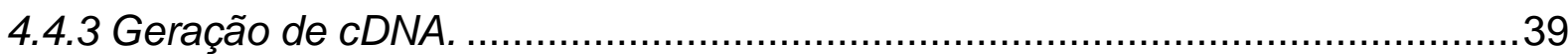

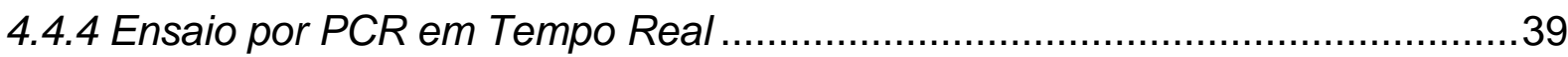

4.5 Imunolocalização de IL-25 e IL-17BR durante a Gestação ............................40

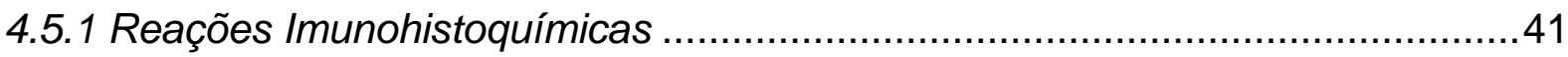

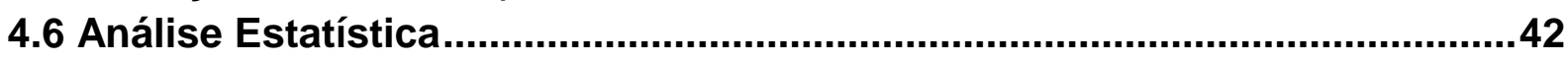

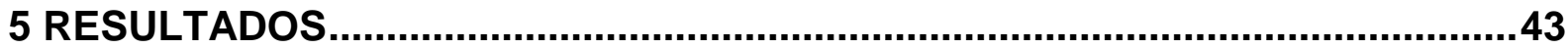

5.1 Análise da Expressão Gênica de IL-25 e seu Ligante IL-17BR em Tecidos Placentários durante a Gestação em Camundongos..........................................44 5.2 Imunolocalização da Citocina IL-25 e do seu Receptor IL-17BR na Interface Materno-Fetal em Camundongos.................................................................46

5.3 Níveis de IL-25 e do Receptor IL-17B na Interface Materno-Fetal .................51

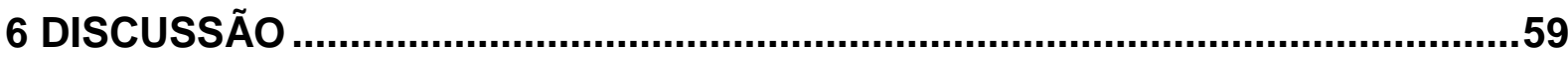




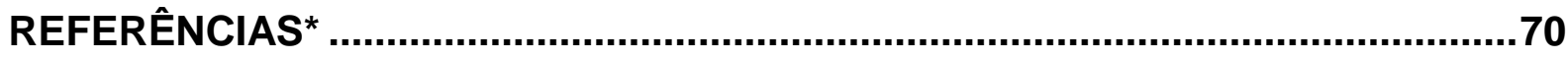

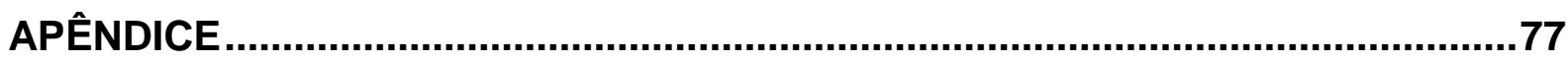

Apêndice A - Análise de Citometria de Fluxo na Porção Fetal da Placenta..............77 Apêndice B - Produção de IL-25 e IL-17BR por Células Trofoblásticas e Linfocitárias na Porção Fetal da Placenta ................................................................................78

Apêndice C - Análise de Citometria de Fluxo na Porção Materna da Placenta.........79 Apêndice D - Produção de IL-25 e IL-17BR por Células Linfocitárias na Porção Materna da Placenta 80 Apêndice E - Produção de IL-25 e IL-17BR por Células Mononucleares do Sangue Periférico (CMNs) em Camundongos Fêmeas Prenhes 
1 INTRODUÇÃO 
Ao longo da gestação, a interação entre tecidos maternos e fetais realiza-se por meio de uma estrutura transitória - a placenta - que cria um microambiente no qual células geneticamente distintas se mantêm em contato e em equilíbrio funcional.

Em primatas e roedores essa associação é intima, na medida em que as células fetais - trofoblásticas - que revestem externamente todo o embrião fazem contato direto com células endometriais e o sangue materno. As interações advindas desta associação ocorrem por meio de uma complexa rede de moléculas reguladoras que permeiam a malha placentária e interagem entre si fornecendo as condições para o sustento gestacional. Hormônios, citocinas, quimiocinas e fatores de crescimento fazem parte do repertório de moléculas sinalizadoras que atuam na interface e asseguram a homeostase entre as células fetais e o organismo materno (YOSHINAGA, 2010; ZHANG et al., 2013).

As citocinas, mediadores solúveis do sistema imunológico, também desempenham um importante papel na homeostase gestacional. Elas atuam na regulação de respostas imunológicas e inflamatórias, medeiam a comunicação intercelular e controlam o recrutamento e a proliferação de leucócitos. Do ponto de vista imunológico, a gestação somente é possível porque uma intrincada rede imunorreguladora de citocinas é ativada, com o objetivo único de desenvolver um estado de tolerância materna, permitindo a implantação e manutenção do embrião dentro do organismo materno (; CHA; SUN; DEY, 2012; WANG et al., 2006). Muitas são as citocinas elencadas como essenciais para a manutenção e sucesso do desenvolvimento embrionário (CHAOUAT et al., 2004, 2007).

Parte das citocinas ativam respostas inflamatórias de defesa orgânica e são denominadas em conjunto pró-inflamatórias, enquanto outras atenuam esse processo e são denominadas de anti-inflamatórias (MOSMANN et al., 1989). Desequilíbrio na produção dessas moléculas está frequentemente associado à fisiopatologia de doenças reprodutivas, como falhas de implantação e perdas fetais (RAGHUPATHY et al., 2001). A IL-25, uma citocina da família da interleucina 17 também conhecida como IL-17E, foi descrita como um fator crucial na indução de 
citocinas anti-inflamatórias, propiciando o predomínio do perfil imunológico Th2 ${ }^{1}$. Os efeitos dessa citocina devem-se preferencialmente por sua ligação ao receptor IL-17BR. Embora muitos trabalhos relatem células produtoras tanto de IL-25 e seu receptor, os mecanismos de atuação desta citocina não estão totalmente elucidados (FORT et al., 2001; LEE et al., 2001).

Trabalhos recentes mostraram uma relevante redução na expressão gênica de IL-25 e seu receptor na placenta de gestantes que sofreram aborto e com história de abortos recorrentes (GIANNUBILO et al., 2012; WANG et al., 2014). Os autores discutiram a possibilidade dessa redução estar levando a um desequilíbrio de citocinas que, por sua vez, pode ser responsável por uma alteração letal no ambiente placentário.

A IL-25 pode desta forma, estar participando da rede de citocinas de perfil Th2, essenciais para o estabelecimento de um microambiente na interface materno fetal tolerante ao feto.

Considerando que citocinas são participantes fundamentais nos eventos de comunicação celular durante toda a gestação, seja na comunicação entre as células embrionárias e maternas ou ainda, entre células dos muitos compartimentos maternos, e que o conhecimento das células produtoras e alvo podem auxiliar na compreensão de suas funções, este estudo avaliou ao longo da gestação em camundongos, a imunolocalização e expressão da IL- 25 e seu receptor na interface materno fetal.

\footnotetext{
${ }^{1}$ Os perfis imunológicos são caracterizados de acordo com a produção de citocinas que as células produzem. Perfis clássicos, mas não únicos, são os Th1 e Th2, sendo o Th1 aqueles relacionados com a defesa mediada por células (linfócitos) e que incluem citocinas de caráter inflamatório e Th2, relacionadas com a produção de anticorpos, e que incluem citocinas anti-inflamatórias.
} 
2 REVISÃO DA LITERATURA 


\subsection{A Interface Materno-Fetal}

Durante a gestação, o diálogo entre os organismos materno e fetal ocorre por meio de regiões especializadas que se desenvolvem no sítio uterino e nas células que revestem o embrião, compondo um ambiente compartilhado e de integração conhecido como interface materno-fetal. Os primeiros passos na formação desse microambiente têm início com o processo de implantação.

\subsubsection{Implantação}

A implantação embrionária é um processo ordenado e complexo que compreende uma sequência de eventos que conduzem o embrião a se estabelecer de forma correta e eficiente no ambiente uterino (CHA et al., 2012; ZHANG et al., 2013). O início do relacionamento materno-fetal é definido com a chegada do embrião ao endométrio, momento em que este se encontra na fase de blastocisto. $O$ blastocisto se apresenta como uma estrutura esférica, oca, composta por duas populações celulares distintas: a massa celular interna ou embrioblasto e o trofectoderma. A massa celular interna, um aglomerado celular que se projeta para dentro da blastocele é a população responsável pela origem dos tecidos embrionários propriamente ditos. Externamente, o blastocisto é revestido por uma camada de células achatadas denominadas trofectoferma ou trofoblasto (DYCE et al., 1987; GRABAREK et al., 2012).

Em camundongos, a implantação embrionária caracteriza-se morfologicamente pelo contato entre as células do trofectoderma e as células epiteliais uterinas, seguido pela invasão do endométrio até que o concepto esteja completamente inserido no estroma endometrial

A primeira etapa desse processo é a fase de aposição, dando início as primeiras interações a partir da aproximação dos microvilos presentes no trofectoderma mural do embrião e das células do epitélio uterino. Em um segundo estágio o contato entre essas células torna-se mais estreito e suas membranas se interdigitalizam caracterizando uma etapa de adesão (ENDERS; SCHLAFKE, 1975). Nesse momento além de modificações na superfície dessas células, como alterações de carga elétrica da membrana e da composição do glicocálice, ocorrem também 
alterações no próprio estroma endometrial, adjacente ao contato com o embrião. 0 contato trofectoderma-epitélio uterino também induz a diferenciação das células embrionárias, que iniciam um processo de poliploidia e agigantamento, passando a ser denominadas de células trofoblásticas primárias gigantes ou células tronco trofoblásticas. Estas células apresentam características fagocíticas e invasivas e são responsáveis pela invasão do embrião no estroma endometrial (BEVILACQUA et al., 2014; HU; CROSS, 2009; SIMMONS; FORTIER; CROSS, 2007).

A adesão do trofoblasto ao endométrio é acompanhada pela apoptose das células epiteliais uterinas que são ativamente fagocitadas pelas células trofoblásticas gigantes, permitindo o contato direto destas células com a membrana basal do epitélio. O processo de invasão trofoblástica é contínuo e acentuado nesta fase permitindo o rápido acesso do embrião ao interstício endometrial e sua intrusão na parede dos capilares subepiteliais, proporcionando um contato direto entre essas células e o sangue materno (BEVILACQUA et al., 1988, 1994, 2009)

\subsubsection{Decidualização}

Durante o processo de implantação do embrião importantes alterações ocorrem no estroma endometrial, tornando-o apto para fornecer as condições necessárias ao desenvolvimento embrionário. Em conjunto estas alterações são denominadas de reação decidual e o processo em si de como decidualização. Este processo inclui modificações morfológicas, funcionais e moleculares no ambiente uterino gerando uma nova estrutura transitória chamada decídua (ABRAHAMSOHN et al., 1983; ABRAHAMSOHN, ZORN, 1993).

Durante a reação decidual o endométrio reestrutura-se em um tecido remodelado, deixando suas características conjuntivas para adquirir um rearranjo epitelial. Os fibroblastos locais sofrem transdiferenciação para células deciduais, assumindo formas poliédricas, tornando-se volumosos e justapostos, passam a acumular lipídeos e glicogênio e alteram o seu padrão de expressão protéica (ABRAHAMSOHN, ZORN, 1993; CROSS et al., 2002; PLAISIER et al., 2011).

A decidualização também promove grande adaptação do sistema vascular, estimulando a angiogênese e o aumento da permeabilidade dos vasos locais. Durante a fase de invasão no interstício endometrial, as células trofoblásticas 
gigantes se interpõem entre as células endoteliais ocupando seus espaços (CROSS et al., 2002) e estabelecendo um contato direto com sangue materno e uma superfície de interação entre os dois organismos (; ADAMSON et al., 2002; BEVILACQUA; ABRAHAMSOHN, 1988, 1989; HEMBERGER et al., 2003; HU; CROSS, 2011).

A decídua tem papel importante na interface materno-fetal, pois integra a porção materna da estrutura placentária. Em camundongos, as primeiras células deciduais são identificadas a partir do $5^{\circ}$ dia de gestação ao redor da câmara de implantação, em sua região antimesometrial. Na região mesometrial, este processo é um pouco mais tardio, iniciando-se ao $7^{\circ}$ dia de gestação. Este tecido, entretanto, constituirá a porção materna da placenta, em intima associação com as células do trofoblasto polar. A decídua é uma estrutura efêmera e dinâmica; enquanto as primeiras células que se decidualizaram iniciam o programa de morte celular (em suas regiões mais próximas ao embrião) a proliferação e diferenciação de novas células deciduais é estimulada na região periférica (KATZ; ABRAHAMSOHN, 1987).

A decídua exibe um padrão peculiar de involução com morte celular progressiva de suas células; no $16^{\circ}$ dia de gestação a decídua mesometrial é uma estrutura quase vestigial (KATZ; ABRAHAMSOHN, 1987). Dentre as muitas funções atribuídas a decídua, acredita-se que seu papel imunológico seja crucial, participando de respostas imunológicas tolerogênicas para permitir o convívio do embrião no organismo materno (LALA et al., 1986; SANGUANSERMSRI; PONGCHAROEN, 2008).

O polo mais extremo da decídua mesometrial é formado por um tecido linfoide secundário, conhecido como glândula metrial, no qual abriga células imunologicamente competentes que estimulam a produção de fatores locais, contribuindo para a manutenção da homeostase gestacional (PAFFARO et al., 2003; WANG et al., 2003).

Dessa forma, componentes maternos e fetais integram um sistema especializado que se forma no ambiente uterino, propiciando as condições para formação de uma superfície de interação que estabelece a Interface materno-fetal. 


\subsubsection{Placentação}

O período que se segue ao processo de implantação embrionária compreende a uma série de modificações por parte das estruturas maternas e fetais, que desenvolvem funções especializadas para aprimorar a interação entre ambos organismos, formando um órgão híbrido e complexo. Esse órgão transitório, conhecido como placenta, estabelece papéis essenciais desde sua formação até o momento do parto. Participa dos mecanismos de ancoragem do concepto no útero, ao mesmo tempo em que exibe um grande potencial endócrino, sendo produtor de diversos hormônios gestacionais, além de um grande número de moléculas reguladoras. É responsável por intermediar as trocas gasosas e metabólicas entre o feto e a mãe e exibe funções imunológicas, por meio das quais participa de muitos dos mecanismos adaptativos que permitem o sucesso da gestação. A placenta, desta forma, é um componente altamente ativo da interface materno-fetal, capaz de manter e regular o ambiente gestacional (BAUER et al., 1998; CROSS et al., 2005; REYNOLDS et al., 1995).

Embora se observe divergências na estrutura e fisiologia da placenta entre espécies de mamíferos, humanos e roedores compartilham a mesma classificação placentária, sendo em ambos os casos do tipo hemocorial. Nesta relação materno-fetal, as células trofoblásticas mantêm contato direto com o sangue materno (ENDERS et al., 1965; LEISER et al., 1994). Neste contexto, a placenta de camundongos, tem se mostrado um importante modelo para a compreensão da fisiologia da placenta humana.

Em camundongos, o processo de placentação tem início ao redor do $7^{\circ}$ dia de gestação a partir de uma estrutura denominada cone ectoplacentário. Esta estrutura, uma excrescência celular de forma piramidal, originada a partir da proliferação do trofoblasto polar que recobre a massa celular interna do blastocisto. Esta estrutura é peculiar a roedores e pode ser considerada como uma pré-placenta, sendo formada por duas populações especializadas de células trofoblásticas: células gigantes secundárias - poliploides e contato direto com o endométrio; apresentam atividade fagocitária e invasiva; células mais internas em contato com a massa celular interna são menos diferenciadas e com intensa capacidade proliferativa (CROSS et al., 2005; MUNTENER; HSU, 1977). 
A diferenciação dessas células trofoblásticas resulta em tipos celulares especializados com diferentes potenciais funcionais, os quais serão precursores na formação de regiões especificas da porção fetal da placenta. Conforme a gestação progride o ambiente placentário torna-se gradualmente mais complexo, atingindo a sua maturidade morfológica ao redor do $13^{\circ}$ dia de gestação. Nesse estágio a placenta murina é constituída por uma porção materna (Fig. 1) - a decídua mesometrial ou basal e a porção fetal - composta por 3 regiões distintas: Zona Juncional, Labirinto e Placa Coriônica (CROSS; WERB; FISHER, 1994).

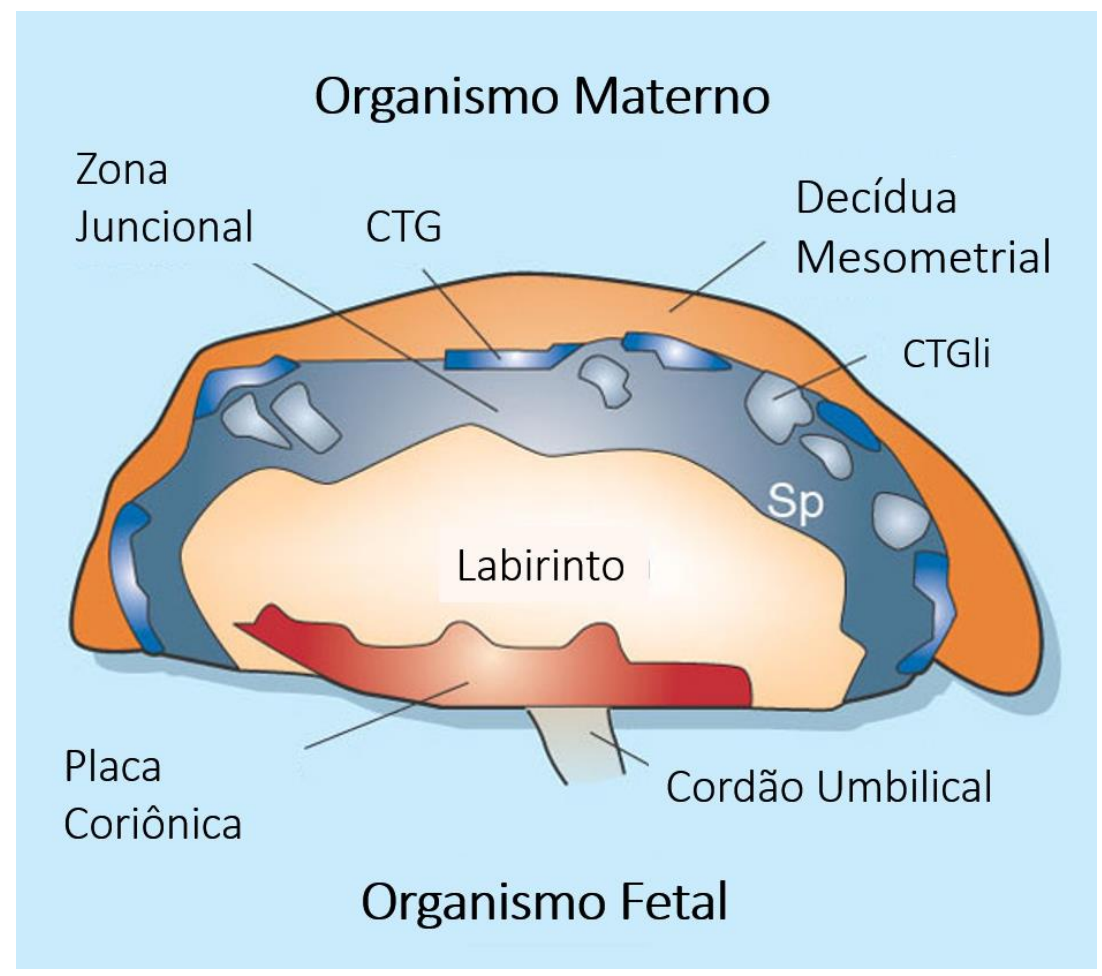

Figura 1 - Representação esquemática da placenta de camundongo madura. Figura representativa das regiões de uma placenta madura. A região fetal é formada pela Placa Coriônica, Labirinto e Zona Juncional enquanto que a materna está representada pela Decídua Mesometrial. Na Zona Juncional notar os seguintes tipos celulares: CTG: Célula Trofoblástica Gigante; CTGli: Células Trofoblásticas de Glicogênio; Sp: Espongiotrofoblasto. Adaptado de Tycko; Efstratiadiset al. (2002)

A zona juncional faz contato com a decídua mesometrial. Em sua região mais próxima da decídua apresenta uma camada de células trofoblásticas gigantes que se diferenciam das células que revestem externamente o cone ectoplacentário (CROSS et al., 2002). As camadas de células trofoblásticas mais internas da zona juncional 
constituem o espongiotrofoblasto, uma população mista de células trofoblásticas algumas com características proliferativas outras com acúmulo de glicogênio (células de glicogênio) (ADAMSON et al., 2002; CROSS, 2005). Essa região é um local de intensa atividade endócrina, associada a produção de hormônios, citocinas e quimiocinas que regulam a fisiologia materna e fetal (AIN; CANHAM; SOARES, 2003). A relevância da zona juncional pode ser inferida sob condições extremas; a redução ou expansão do espongiotrofoblasto está associada a falhas de desenvolvimento fetal. Além disso desempenha papel estrutural importante no desenvolvimento da camada labiríntica subjacente (JOHN; HEMBERGER, 2012)

O labirinto representa uma grande área da superfície placentária que abriga redes vasculares materna e fetal, separadas e altamente ramificadas que se entrelaçam tortuosamente, permitindo de forma eficiente as trocas de moléculas (nutrientes e gases) entre o feto e a mãe. O sangue da mãe chega às porções mais próximas da zona juncional por meio de ramificações da artéria uterina. Estas artérias são abertas por trofoblásticas gigantes e sofrem remodelação. Neste processo suas células endoteliais e musculares são substituídas por células trofoblásticas que migram para a decídua a partir da zona juncional (ADAMSON et al., 2002). O sangue materno dessa forma chega a placenta por meio de canais trofoblásticos. O sangue fetal percorre os capilares fetais no amplamente distribuídos por todo o labirinto. A barreira placentária que se forma, entre o sangue fetal e o materno, é constituída, além das células endoteliais dos capilares fetais, por células trofoblásticas oriundas da diferenciação de células da base do cone ectoplacentário, região denominada de placa coriônica. Estas células trofoblásticas se diferenciam e formam três camadas: duas camadas sinciciais, voltadas para o endotélio fetal, e uma camada de células trofoblásticas gigantes sinusoidais em contato com sangue materno. Estas camadas atendem à demanda circulatória para o desenvolvimento embrionário/fetal enquanto atuam como uma barreira seletiva entre as circulações fetal e materna (SIMMONS et al., 2007; WATSON; CROSS, 2005). O fluxo sanguíneo materno desta forma, atravessa a camada juncional através dos canais trofoblásticos e é liberado na base do labirinto de onde banhará o trofoblasto labiríntico (GEORGIADES; FERGUSON-SMITH; BRTON, 2002).

$\mathrm{Na}$ base do labirinto encontra-se a placa coriônica que recebe os vasos do cordão umbilical que se ramificam por toda a extensão da placa. A placa coriônica é 
formada pela associação do ectoderma extra-embrionário (que mantém uma estrutura epitelióide) e do mesoderma extra-embrionário e alantoideano (ROSSANT; CROSS, 2001).

Os eventos celulares e moleculares associados aos processos de implantação e formação da placenta são orquestrados por moléculas reguladoras e sinalizadoras, as quais são produzidas e liberadas na interface materno-fetal, participando de um intenso cross-talking entre os organismos da mãe e do feto. Estas moléculas são expressas espaço-temporalmente pelos diferentes tipos celulares da placenta e incluem principalmente hormônios, citocinas, quimiocinas e fatores de crescimento. Essa gama de moléculas sinalizadoras tem se mostrado capaz de participar deste diálogo, desempenhando papéis funcionais em muitos dos processos envolvidos na gestação, incluindo a preparação do endométrio para o recebimento do embrião, controle da adesão e invasão do trofoblasto, regulação hormonal do ambiente materno, imunorregulação gestacional, além da regulação das próprias funções placentárias vitais para o desenvolvimento fetal (ENTRICAN et al., 2002; ZENCLUSSEN et al., 2005, 2006).

\subsection{Imunologia da Gestação}

O sistema imunitário é de vital importância para estabelecimento de uma interface materno-fetal saudável. Ele atua a partir de uma intrincada rede imunorreguladora, com a finalidade de promover um ambiente competente e permitir o estabelecimento e desenvolvimento do embrião no organismo materno (JABBOUR et al., 2009).

\subsubsection{Imunidade Materno-Fetal}

Durante toda a gestação, a interface materno-fetal recebe células imunológicas que se distribuem em diferentes territórios. Populações de linfócitos T, macrófagos e células NK fazem parte do vasto repertório das células de atividade imunológica que secretam mediadores celulares contribuindo ativamente para o desenvolvimento e manutenção do útero grávido como um local imunologicamente privilegiado (ERLEBACHER et al., 2013). 
Os linfócitos $T$ auxiliadores (CD4+) são as principais células efetoras da resposta imunológica e desempenham um papel primordial na modulação do sistema imunitário. Dependendo do contexto em que essas células $\mathrm{T}$ (naives) se maturam, os linfócitos sucessores se especializam funcionalmente em diversos subgrupos categorizados pelo perfil de citocinas que secretam (exemplo: células Th1, Th2, Th17, Th9 e Treg) (NAKAYAMADA et al., 2012; ZHOU et al., 2009). As citocinas, moléculas protéicas de sinalização celular, são produzidas por distintos tipos celulares que participam no controle das respostas imunológicas e suas ações podem influenciar tanto as próprias células que as secretam, em um efeito autócrino, como sobre células vizinhas, exercendo uma função parácrina. Em ambos os casos as citocinas se classificam entre dois grandes grupos: citocinas pró-inflamatórios e citocinas anti-inflamatórias (O'GARRA et al., 1998; ROMAGNANI et al., 2000).

Trabalhos mais antigos classificavam células $T$ auxiliares apenas em subpopulações Th1 ou Th2; muitos estudos sobre a imunologia da gestação referem somente estas classes de linfócitos, apesar do conhecimento atual das demais (Revisado de CHAOUAT et al., 2004) As células Th1 são caracterizadas pela expressão das citocinas pró-inflamatórias a interleucina (IL)-2, IFN- $\gamma$ e TNF- $\alpha$, estando envolvidas na imunidade celular, nos processos de rejeição e na exacerbação da inflamação (MOSMANN et al., 1996). As células Th2 expressam IL-4, IL-5 e IL-13, participam da imunidade humoral e estão presentes em processos alérgicos estimulando a produção de lgE (MOSMANN et al., 1986; RAGHUPATHY et al, 2001).

O processo inflamatório é uma resposta biológica natural às interferências na homeostase tecidual, atuando como um mecanismo de reparação histológica. Durante a gestação, a presença de um ambiente pró-inflamatório promove as alterações fisiológicas necessárias para permitir a invasão das células trofoblásticas no ambiente uterino, o remodelamento do estroma endometrial durante o processo de implantação e consequentemente o estabelecimento da interface materno-fetal (DEKEL et al., 2010; MOR et al., 2011). No entanto, nas fases subseqüentes à implantação, o perfil inflamatório deve ser contrabalanceado e atenuado a fim de garantir o progresso da gestação (JABBOUR et al., 2009; SAITO et al., 2010; WILCZYNSKI et al., 2005). 
Diferentes citocinas atuam em diferentes períodos da gestação. A receptividade uterina está associada à um ativo perfil pró-inflamatório, quando a participação de citocinas como IL-1, IL-6, IFN- $\gamma$ e TNF- $\alpha$ tem sido considerada como de fundamental importância para a implantação embrionária (CHAOUAT et al., 2007). No período pós-implantacional e de formação da placenta, ocorre o controle desse perfil inflamatório por meio da secreção de citocinas imunorreguladoras e de perfil Th2, tais como a IL-10, IL-8 e IL-4 (PICCINNI et al., 2007; SAITO et al., 2007). No final da gestação, quando o organismo materno se prepara para o parto, citocinas pró-inflamatórias voltam a ser intensamente expressas no ambiente uterino.

O equilíbrio entre as vias pró e anti-inflamatórias parece ser precisamente controlado a cada etapa da gestação, visto que desequilíbrios no perfil inflamatório podem contribuir para inúmeras desordens reprodutivas incluindo a endometriose, menorragia, dismenorreia, pré-eclâmpsia e parto prematuro (JABBOUR et al., 2009; MAYBIN et al., 2011).

As células auxiliadoras (Th) são moduladas por outra classe de linfócitos: - as células $\mathrm{T}$ reguladoras (Treg). Além de sua capacidade em produzir citocinas imunorreguladoras, tais como o TGF- $\beta$ e a interleucina 10, as células Tregs suprimem a ativação dos linfócitos $T$ auxiliares a partir de uma interação célula-célula. Esses linfócitos reguladores são importantes para a manutenção do sistema imunológico materno; a deficiência de Tregs no ambiente placentário está associada a complicações como falha de implantação, abortos espontâneos e pré-eclâmpsia (revisado de ALUVIHARE et al., 2004).

Entre os mecanismos envolvidos na regulação de respostas imunitárias, um papel importante é desempenhado pelas moléculas do receptor de morte programada (PD1) e os seus ligantes PDL1 e PDL2, que atuam na sinalização negativa da ativação das células T. PDL1 / 2 estão expressos em células apresentadoras de antígeno ativadas ou quando na presença de intérferon gama (IFN- $\gamma$ ) e em uma ampla variedade de células parenquimatosas ou endoteliais de diversos órgãos, incluindo coração, rim, pâncreas e placenta (BLANK et al., 2005; GULERIA et al., 2005), de forma constitutiva ou induzida.

A interação do ligante ao PD1, controla a ativação dos linfócitos T através de diversos mecanismos, que incluem: o controle da proliferação, alteração da produção 
de citocina e a indução da morte celular. Como resultado do seu papel na sinalização negativa das células $T$, levantou-se a hipótese de que PD1/PDL(1/2) podem desempenhar um papel importante na tolerância imunitária materna, levando a investigação de suas funções na interface materno-fetal em humanos e em modelos animais (BLANK et al., 2005; HORI et al., 2006).

Petroff e colaboradores $(2003,2005)$ demonstraram que durante a gestação em humanos, o ligante PDL2 é expresso nas células trofoblásticas no período inicial da gravidez, enquanto PDL1 é expresso ao longo de todo período gestacional. Enquanto a expressão de PDL1 inicia-se ainda baixa no primeiro trimestre e aumenta progressivamente ao longo da gestação, o PDL2 é predominantemente expresso pelo sinciciotrofoblasto durante o início do desenvolvimento placentário diminuindo ao longo da gestação. Interessantemente, a análise em modelo murino demonstrou a presença de PDL1 na decídua materna e não no trofoblasto, sugerindo que a decídua pode participar da supressão de células T aloantígeno específicas.

Recentemente foram descritos novos subconjuntos específicos de linfócitos $T$ CD4+ presentes no ambiente placentário e exercendo atividades durante a gestação. Entre eles destacam-se os linfócitos Th17, conhecidos por estarem envolvidos nos mecanismos patogênicos de doenças auto-imunes e de rejeição de transplantes. Estes linfócitos secretam principalmente a interleucina 17, uma citocina de caráter pró-inflamatório, capaz de induzir atividade Th1. Evidências experimentais sugerem que seja necessário um balanço adequado entre células Treg e Th17 para o sucesso gestacional, uma vez que o aumento de IL-17 está relacionado a complicações e abortos (DARMOCHWAL-KOLARZ et al., 2012; SAITO et al., 2010; SANTNER-NANAN et al., 2008; WANG et al., 2010).

Outra classe de linfócitos atuante na interface materno-fetal foi recentemente identificada como Th9. Os linfócitos pertencentes a este subgrupo se caracterizam pela produção da interleucina 9 , uma citocina envolvida em processos de diferenciação e proliferação de células Th2, e que coopera com a IL-4 em mecanismos de regulação da síntese de anticorpos. Por seu papel imunorregulador, especula-se que a IL-9 participe na interface materno-fetal evitando a ativação imunológica materna contra o feto semi alogênico (GOSWAMI et al., 2011; HABBEDDINE et al., 2014). 
Dentro do contexto imunológico, a regulação da homeostase no útero gravídico tem implicações importantes para a imunidade materna. As interações e mecanismos envolvidos no estabelecimento de um ambiente tolerogênico na interface de contato com a placenta fetal se desenvolve em processos complexos ainda não completamente elucidados. Nos últimos anos, um grande número de estudos vem sendo realizados na tentativa de desvendar a identidade de alguns fatores e mecanismos por meio da qual opera a rede de modulação imunológica que sustenta a gestação. Apesar disso, a função e expressão de muitas delas ainda permanece no campo especulativo, como é o caso da IL-25.

\subsubsection{Interleucina 25 (IL-25)}

Estudos recentes identificaram a expressão da interleucina 25 no ambiente uterino em gestantes humanas saudáveis e uma redução relevante em seus níveis em pacientes com abortos recorrentes (GIANNUBILO et al., 2012; WANG et al., 2014).

A IL-25 é uma citocina da família da interleucina 17, também conhecida como IL-17E, possui baixo grau de homologia com as demais isoformas e não compartilha funções biológicas comuns. A IL-25 tem sido descrita como importante fator indutor de citocinas anti-inflamatórias, como a IL-4, IL-5 e IL-13, propiciando o predomínio do perfil imunológico Th2. Embora muitos trabalhos relatem diversas células como produtoras de IL-25, os mecanismos que regulam a expressão desta citocina por essas células não estão totalmente compreendidos (FORT et al., 2001).

Recentemente, Yu e colaboradores (2010) mostraram que a indução de IL-25 por alérgenos é inibida quando as vias ErK e/ou p38 MAP quinase são bloqueadas, mas não após a inibição das vias NFKB or PI-3 quinase. Estes resultados sugerem que a via MAPK é vital para a expressão de IL-25.

IL-25 desencadeia respostas celulares mediadas pela sua interação com o receptor heterodimérico composto de IL-17AR e IL-17BR, porém a contribuição de cada subunidade para a sinalização das vias downstream ainda é desconhecida. $O$ complexo IL-17AR/BR se ativa apenas pela ligação especifica da IL-25 à unidade IL-17BR. O receptor IL-17BR foi classicamente descrito como ligante de IL-17B; no entanto a afinidade de IL-25 a esse receptor é maior do que a própria IL-17B. A 
expressão de IL-17BR já foi demonstrada tanto em células epiteliais como em diversas células imunológicas ( $T$ CD4+, células NK, mastócitos, eosinófilos) (LEE et al., 2001; RICKEL et al., 2008; YU et al., 2010).

A IL-25 está associada ao estímulo de células Th2 para secreções especializadas e também participa da diferenciação de linfócitos para um perfil do tipo Th2. Recentemente foi demonstrado que as células Th9 expressam o receptor IL-17BR e sob o estímulo de IL-25 produzem IL-9, desempenhando um papel importante na imunidade protetora (ANGKASEKWINAl et al., 2010; HURST et al., 2002).

A ligação IL-25-receptores pode levar à ativação de pelo menos três diferentes vias intracelulares e variadas repercussões: i) ativação de NFATc1 e JunB que leva a um aumento na expressão de IL-4 por Linfócitos Th2; ii) expressão PDL1 através das vias de sinalização JNK e STAT3, sendo o PDL1 um ligante imunossupressor capaz de inibir a ativação de células $T$ autólogas em várias doenças auto-imunes; iii) ativação do fator de transcrição NF-kappa $\beta$ com produção de IL-8, indicando um papel na atenuação da inflamação (ANGKASEKWINAI et al., 2007, 2010; TAMACHI et al., 2006; WONG et al., 2007).

Além de suas funções imunológicas, a IL-25 parece atuar também em outros mecanismos celulares. Recentemente o trabalho de Wang e colaboradores (2014) mostrou que durante a gestação em humanos, a secreção de gonadotrofina coriônica pelo trofoblasto pode regular a expressão de IL-25/L-17BR em células deciduais, que autocrinamente são induzidas a proliferar por meio da ativação da via JNK e AKT, contribuindo assim para o estabelecimento e manutenção da gestação.

A presença de IL-25 na interface materno fetal pode desta forma, ser incluída na rede de citocinas de perfil imunorregulador, essencial para o estabelecimento de um microambiente tolerante ao feto durante o segundo período gestacional. Considerando que a interação IL-25-receptores possa estar orquestrando a regulação e modulação de células imunológicas no microambiente placentário, este estudo avaliou ao longo da gestação em camundongos, a expressão da IL-25 e do seu principal receptor IL-17BR na interface materno fetal. 
3 OBJETIVOS 


\subsection{Objetivo Geral}

Determinar a expressão da citocina IL-25 e seu receptor IL-17BR em componentes que formam a interface materno-fetal durante a gestação em camundongos.

\subsection{Objetivos Específicos}

- Avaliar o perfil de expressão gênica de IL-25, assim como seus receptores IL-17BR e IL-17AR, nas células placentárias de camundongos fêmeas prenhes. Abordagem: Ensaios de RT-PCR.

- Identificação das células produtoras de IL-25 e IL-17BR nos compartimentos placentários e em células periféricas do sangue materno. Abordagem: Citometria de Fluxo.

- Localizar a distribuição da citocina e receptor nos compartimentos materno e fetal da estrutura placentária ao longo da gestação. Abordagem: Imunohistoquímica. 
4 MATERIAIS E MÉTODOS 


\subsection{Animais}

Foram utilizados camundongos Mus musculus domesticus, da linhagem CD-1, mantidos no Biotério do Departamento de Biologia Celular e do Desenvolvimento do Instituto de Ciências Biomédicas da Universidade de São Paulo sob regime ad libidum de água e ração granulada. As fêmeas de aproximadamente 3 meses foram mantidas com machos durante a noite (2: 1) e o acasalamento bem-sucedido foi verificado diariamente pela presença da rolha vaginal, sendo este considerado metade do primeiro dia de gestação $(0,5 \mathrm{dg})$. Todas as fêmeas prenhes foram sacrificadas por deslocamento cervical. Todos os procedimentos e manejo dos animais foram realizados de acordo com as orientações fornecidas pela Sociedade Brasileira de Ciência em Animais de Laboratório (SBCAL) e autorizado pela Comissão de Ética no Uso de Animais (CEUA, no 41; fls 18; livro 03) do Instituto de Ciências Biomédicas da Universidade de São Paulo (em anexo).

\subsection{Amostras}

Para a análise da interface materno-fetal, foram analisados tecido placentários e o sangue periférico de camundongos fêmeas prenhes em diversos dias de gestação.

\subsubsection{Obtenção dos Sítios de Implantação e Placentas.}

Cornos uterinos das fêmeas prenhes foram coletados e dissecados em 5.5, 7.5, 10.5, 13.5, 16.5 e 19.5 dias de gestação em tampão fosfato estéril (PBS), imediatamente após ao deslocamento cervical. Os cornos uterinos foram cortados longitudinalmente e os sítios de implantação de 5,5 e 7.5 dias de gestação e as placentas de 10.5, 13,5, 16,5 e 19,5 dias de gestação, foram separadas do miométrio. Sob microscópio estereoscópico a decídua materna foi gentilmente isolada da porção fetal da estrutura placentária e ambos compartimentos teciduais foram devidamente processados para as avaliações histológicas, protéicas e gênicas. 


\subsubsection{Obtenção do Sangue Periférico.}

Fêmeas prenhes nos diversos dias de gestação (10.5, 13.5, 16.5 e 19.5) foram previamente anestesiadas com ketamina e xilazina (Agner União, São Paulo, SP, Brasil) (i.p., 50 e $5 \mathrm{mg} / \mathrm{kg}$, respectivamente, 1:1/v:v) e tiveram o sangue coletados diretamente do tronco quando sacrificadas por decapitação.

\subsection{Níveis Protéicos de IL-25 e do Receptor IL-17BR nos Compartimentos da Interface Materno-Fetal}

Para a análise dos níveis protéicos dentro de cada grupo experimental foram realizados 2 pools de amostras, sendo que cada um continha material obtido de 3 fêmeas. As células foram então isoladas e analisadas conforme descrição a seguir.

\subsubsection{Isolamento das Células Trofoblásticas (Porção Fetal da Placenta).}

As porções fetais de placentas de 10,5, 13,5, 16,5 e 19,5 dias de gestação foram dissecadas em ambiente estéril (em fluxo laminar, Vecco Ind., Campinas, Brasil), mantidas em solução PBS e lavadas 3 vezes em meio D-MEM (Sigma®-Aldrich, St. Louis, MO, EUA). Com o auxílio de um bisturi cirúrgico (Embramed, São Paulo, Brasil) os tecidos foram seccionados e seus fragmentos transferidos para tubos estéreis de $50 \mathrm{~mL}$ (Falcon, Tewksbury, MA, USA) contendo 0,03 $\mathrm{g}$ de Dispase II (Sigma®-Aldrich) em $40 \mathrm{~mL}$ de meio D-MEM. Os tubos foram mantidos por 50 min em banho Maria a $37^{\circ} \mathrm{C}$ e em seguida centrifugados a $4{ }^{\circ} \mathrm{C}$, 1000 rpm, durante $10 \mathrm{~min}$. O sobrenadante foi descartado e o pellet transferido para outro tubo Falcon contendo $15 \mathrm{~mL}$ de tripsina (Instituto Adolfo Lutz, São Paulo, Brasil) acrescido de $0,0015 \mathrm{~g}$ de DNAse I (Sigma®-Aldrich) sendo mantida à temperatura ambiente por $10 \mathrm{~min}$. A solução de tripsina foi inativada em meio D-MEM contendo 20 $\%$ de soro fetal bovino (SBF, CULTILAB SA, Campinas, Brasil) e seguiu para nova centrifugação $\left(4^{\circ} \mathrm{C}, 1000 \mathrm{rpm}, 10 \mathrm{~min}\right)$. O lisado celular foi tratado por $10 \mathrm{~min}$ com solução de hemólise (0,8 \% de cloreto de amônio) a temperatura ambiente, filtrado (70 $\mu \mathrm{m}$, BD Biosciences, Erembodegem, Bélgica) e novamente centrifugado. As células obtidas foram contadas, sua viabilidade avaliada pelo azul de Tripan em contador automático (Countess, Invitrogen, Carlsbad, Califórnia, EUA) e mantidas em freezer $-80 \stackrel{\circ}{\mathrm{C}}$ até o momento do uso. 


\subsubsection{Isolamento das Células Deciduais (Porção Materna da Placenta)}

As porções decíduais (porção materna da placenta) foram dissecadas de placentas de 10,5, 13,5, 16,5 dias de gestação em solução de PBS, lavadas 3 vezes em meio D-MEM e fragmentadas com o auxílio de um bisturi. $O$ tecido foi transferido para tubos Falcon contendo $5 \mathrm{~mL}$ de Solução Enzimática $(0,025 \mathrm{~g}$ de Colagenase II e $0,03 \mathrm{~g}$ Protease em PBS) sendo mantido por $30 \mathrm{~min}$ a $37^{\circ} \mathrm{C}$. Em seguida foi adicionado $5 \mathrm{~mL}$ da solução de bloqueio (DEMEM + $20 \% \mathrm{SBF}$ ) e as amostras submetidas a centrifugação a $4{ }^{\circ} \mathrm{C}$ e $1000 \mathrm{rpm}$ durante $5 \mathrm{~min}$. Descartou-se $\mathrm{o}$ sobrenadante e o pellet foi ressuspendido em $5 \mathrm{~mL}$ de solução de hemólise $(0,8 \%$ de cloreto de amônio) por $10 \mathrm{~min}$ em temperatura ambiente. Seguiu-se nova centrifugação e as células isoladas foram recuperadas para contagem e posterior criopreservação.

\subsubsection{Isolamento de Células Mononucleares do Sangue (CMNs)}

As CMNs foram obtidas a partir de amostras de sangue periférico coletado das fêmeas prenhes. O sangue foi diluído em PBS na proporção 1:1. As suspensões das células mononucleares (CMNs) foram obtidas após centrifugação por 30 min a 1800 rpm, por meio de gradiente de Ficoll Hypaque (Amersham Pharmacia Biotech, NJ, EUA). As células obtidas foram contadas e sua viabilidade avaliada pelo azul de Tripan em contador automático (Countess, Invitrogen). Para a criopreservação, as CMNs foram colocadas em solução de congelamento contendo $90 \%$ de SFB e $10 \%$ de DMSO com aproximadamente $5 \times 10^{6}$ células por tubo e transferidas para 0 freezer $-80^{\circ} \mathrm{C}$.

\subsubsection{Criopreservação das Células Isoladas}

Após o isolamento das células trofoblásticas, deciduais e mononucleares do sangue (CMNs), as mesmas foram ressuspendidas em $900 \mu \mathrm{L}$ de soro fetal bovino (SFB, Cultilab) e $100 \mu \mathrm{L}$ de dimetilsulfóxido (DMSO, Merck, Darmstadt, Alemanha) condicionados em tubos de criopreservação e colocados em suporte contendo isopropanol (Merck, Darmstadt, Alemanha) e transferidas para freezer $-80{ }^{\circ} \mathrm{C}$ até análise por citometria de fluxo. 


\subsubsection{Citometria de Fluxo}

As células de placenta fetal, decídua e CMNs previamente isoladas foram descongeladas e mantidas em estufa de $\mathrm{CO}_{2}$ em placas de Petri contendo meio DMEM por 1 hora, antes da marcação celular. As células recuperadas foram transferidas para tubos de citometria e centrifugadas a $1000 \mathrm{rpm}, 10 \mathrm{~min}, 10 \stackrel{\circ}{ } \mathrm{C}$. Ao pellet obtido foi adicionado $200 \mu \mathrm{L}$ de solução de bloqueio (PBS $+10 \%$ SFB) e mantidas por 15 min a temperatura ambiente. Após o período de bloqueio as células foram lavadas com PBS e adicionados os anticorpos primários: IgG de cabra anti-IL-17BR de camundongo (1:40 em solução de bloqueio) (R\&D Systems, Minneapolis, MN, EUA) e IgG de rato anti-CD45 conjugado com a APC $\left(2 \mu \mathrm{l} / 10^{6}\right.$ células; BD Biosciences, Erembodegem, Bélgica) para a marcação extracelular de receptor e linfócitos respectivamente. Depois de incubadas por 30 minutos em temperatura ambiente, as células foram lavadas com PBS e receberam o anticorpo secundário IgG de rato anti-cabra acoplado a PECy-5 (1:100; Thermo Fisher Scientific Inc, Waltham, Massachusetts, EUA) para conjugação com IL-17BR (30 minutos no escuro); posteriormente as amostras foram lavadas e fixadas em tampão (Cito Fix A, Caltag Lab. Inc, Buckingham, Inglaterra).

Após esta etapa, as células foram permeabilizadas em tampão (Cito PermB, Caltag Lab. Inc) durante 20 min e incubadas com anticorpos IgG de rato anti-IL-25 de camundongo conjugado a PE $\left(10 \mu \mathrm{l} / 10^{6}\right.$ células; R\&D System, Minneapolis, MN, USA), IgG de rato anti-citoqueratina 8 de camundongo (para detectar a população de células trofoblásticas, 1:40; TROMA-I, DSHB, lowa, EUA) e IgG de rato anti-FVS510 de humano conjugado a Amcyan (para viabilidade celular; Biosciences, Franklin Lakes, NJ, EUA) durante 30 minutos à temperatura ambiente. Após esse período foi adicionado o anticorpo secundário $\operatorname{lgG}$ de macaco anti-rato conjugado a FITC (1:100), por 30 minutos, no escuro. Posteriormente, as células foram ressuspendidas em solução isotônica e o número relativo de cada população avaliado pela aquisição de 100.000 eventos em aparelho de citometria de fluxo (BD Canto ${ }^{\mathrm{TM}}$, Erembodegem, Bélgica). A análise e reanálise foram realizadas com o software FlowJo (Tree Star, INc., Ashland, OR, EUA). 


\subsection{Expressão Gênica da Citocina e seus Receptores em Sítios de Implantação e Placenta em Diferentes Dias de Gestação}

Todas as amostras de placentas coletadas foram subdivididas em lotes, os quais continham ao menos 3 animais de cada período experimental.

\subsubsection{Análise da Expressão Gênica por qRT-PCR}

As porções fetais da placenta e a decídua coletada em cada dia de gestação foram homogeneizadas com o auxílio de um homogeneizador de tecidos Precellys 24 (Uniscience, Miami, FL, USA) e então processadas para as análises de expressão gênica (RT-PCR, reverse transcriptase polymerase chain reaction e qRT-PCR, quantitative real time) as quais, por sua vez, foram realizadas sempre em triplicatas.

\subsubsection{Extração de RNA Total}

A extração e purificação do RNA total foram realizadas através de colunas do kit de extração RNeasy (Qiagen, Valencia, CA, USA) de acordo com as especificações do fabricante. Os tecidos foram homogeneizados em $600 \mu \mathrm{L}$ de tampão RLT (1 \% 14,3 M- $\beta$-mercaptoetano) e em seguida centrifugados por 3 min a $12000 \mathrm{rpm}$. O sobrenadante obtido foi transferido para novo tubo contendo etanol 70 $\%$ na proporção 1:1. A solução foi homogeneizada com pipeta e $700 \mu \mathrm{L}$ foram transferidos para as colunas de RNeasy apoiadas em tubos de $2 \mathrm{~mL}$ e centrifugados por 15 segundos a $10000 \mathrm{rpm}$. O lavado foi descartado e adicionou-se $700 \mu \mathrm{L}$ de tampão RW1 sobre as colunas de extração, que seguiram para nova centrifugação (15 segundos, $10000 \mathrm{rpm}$ ). A cada coluna foi adicionado $500 \mu \mathrm{L}$ de Tampão RPE e novamente centrifugado, na sequência adicionou-se outros $500 \mu \mathrm{L}$ de Tampão RPE e realizou-se nova centrifugação de $2 \mathrm{~min}$ a $10000 \mathrm{rpm}$. As colunas foram então reposicionadas sob novos tubos de $1,5 \mathrm{~mL}$ aonde foram adicionados $30 \mu \mathrm{L}$ de água RNAse-free. As amostras foram então centrifugadas por $1 \mathrm{~min}$ a $10000 \mathrm{rpm}$ e os tubos contendo o RNA extraído foram armazenados em freezer a $-80{ }^{\circ} \mathrm{C}$. As concentrações de RNA foram determinadas por espectrofotometria (absorbância 260 
$\mathrm{nm}$ ) e a pureza foi avaliada pelos valores das razões: $260 / 280$ e 230/260 nm; os espécimes foram mantidos a $-80^{\circ} \mathrm{C}$ até o momento de sua utilização.

\subsubsection{Geração de cDNA.}

Para a remoção do DNA genômico, o RNA total extraído foi incubado por 15 min em uma solução contendo: 2 pL DNase I, 2 pL solução tampão DNase 10X e água-DEPC para um volume final de 20 pL. O bloqueio da reação foi realizado com $25 \mathrm{mM}$ EDTA, por $10 \mathrm{~min}$, a $65^{\circ} \mathrm{C}$.

O cDNA foi sintetizado a partir de 1 ug de RNA total utilizando Super ScriptIII First-Strand Synthesis Super Mix para qRT-PCR (Invitrogen, Carlsbad, CA, USA) tal como recomendado pelo fabricante, em termociclador (Eppendorf Mastercycler Gradient EP S Thermal Cycler, Eppendorf AG, Germany). A cada $1 \mu \mathrm{g}$ de RNA foram adicionados $5 \mu \mathrm{L}$ de 2X RT Mix, $1 \mu \mathrm{L}$ de RT Enzima Mix, completando-se com água DEPEC para o volume total de $20 \mu \mathrm{L}$. Os tubos foram incubados por 10 min a $25^{\circ} \mathrm{C}$, por $30 \mathrm{~min}$ a $50^{\circ} \mathrm{C}$ e finalmente mantidos a $85^{\circ} \mathrm{C}$ por $5 \mathrm{~min}$. Em seguida a solução foi tratada com RNase $\mathrm{H}$ e incubada por mais 20 min a $37^{\circ} \mathrm{C}$. Os cDNAs sintetizados foram quantificados e estocados a $-20^{\circ} \mathrm{C}$ até o momento de uso.

\subsubsection{Ensaio por PCR em Tempo Real}

Os cDNAs obtidos foram amplificadas utilizando a técnica de qPCR com o reagente SYBR Green PCR Master Mix (Life Techonologies, Carlsbad, Califórnia, EUA) e os iniciadores (IDT, San Diego, EUA) na concentração de $10 \mathrm{pmols} / \mu \mathrm{L}$, conforme descrição do fabricante.A sequência dos oligonucleotídeos utilizados para os genes $I L-25$, seus receptores $I L-17 B R / I L-17 A R$ e para o gene de controle interno da reação YWHAZ estão descritos na Tabela 1. 
Tabela 1 - Lista da sequência de oligonucleotídeos para os genes estudados

\section{Genes}

\section{IL-25}

Interleukin 25[Mus musculus]

IL-17BR

Interleukin 17 receptor $B$ [Mus musculus]

IL-17AR

Interleukin 17 receptor A[Mus musculus]

\section{YWHAZ}

Tyrosine 3-monooxygenase/tryptophan 5monooxygenase activation protein, zeta polypeptide [Mus musculus]

S: primer sense, A: primer antisense
Sequência (5` - 3`)

S: ATGTACCAGGCTGTTGCATTCTTG

A: CTAAGCCATGACCCGGGGCC

S: GCTGGATACTCCGGGGGCCA

A: TGCCACTCACGCAGATCTTG

S: TGAGCTGCAGAGTCAAGAATAG

A: GCTGGGTAGAGGAAACACTAAG

S: GAAGCCACA ATGTTCTTGGCCCAT

A: AAACCA ACAGAG ACTTGGAAGCAC

As amostras de cDNA foram submetidas a $95{ }^{\circ} \mathrm{C}$ por 10 min (desnaturação inicial), 40 ciclos de $15 \mathrm{~s}$ a $95^{\circ} \mathrm{C}, 60 \mathrm{~s}$ a temperatura de anelamento específico para as oligossondas (iniciadores, ver Tabela 1) no termociclador StepOnePlus (Applied Biosystems, Foster City, Califórnia, EUA). Após a ciclagem, as amostras foram imediatamente submetidas à curva de dissociação (Melt Curve): $95^{\circ} \mathrm{C}$ por $15 \mathrm{~s}, 60^{\circ} \mathrm{C}$ por 1 min e 15 s para cada intervalo de $0,3^{\circ} \mathrm{C}$ até $95^{\circ} \mathrm{C}$.

Para o controle interno utilizou-se o gene Ywhaz. Para o controle negativo, foi utilizado um mix de amplificação completo no qual o cDNA foi substituído por água.

Os resultados foram analisados utilizando o Software GeneAmp (Applied Biosystems, Foster City, CA, EUA) de acordo o método $2^{\wedge} \Delta \Delta C T$ de análise tendo o gene Ywhaz para normalização da expressão dos genes de interesse.

\subsection{Imunolocalização de IL-25 e IL-17BR durante a Gestação}

Os sítios de implantação e as placentas dos diferentes dias de gestação obtidos foram fixados por imersão, por 4 a 6 horas, em solução de $4 \%$ paraformaldeído em PBS. Após este período as amostras foram lavadas em PBS e submetidas aos procedimentos rotineiros para inclusão em parafina Histosec $\circledast$ (Merck KGaA, Darmstadt, Alemanha). Secções de $5 \mu \mathrm{m}$ de espessura foram obtidas e aderidas as lâminas histológicas previamente silanizadas (Silane: 
3-aminopropyltriethoxysilane, A-3648 Sigma) e em seguida desparafinizadas, hidratadas em série decrescente de etanol e submetidas ao protocolo a seguir detalhado.

\subsubsection{Reações Imunohistoquímicas}

O resgate dos sítios antigênicos foi realizado incubando as lâminas com os cortes histológicos por 15 min em tampão citrato pH 6,0 a alta pressão, seguida de lavagem em água corrente por $10 \mathrm{~min}$. O bloqueio da peroxidase endógena foi realizado por tratamento com $3 \%$ de $\mathrm{H}_{2} \mathrm{O}_{2}$ em 0,02 M tampão TRIS-salina (TBS) em 5 incubações de 2,5 min cada e o bloqueio de ligações não específicas obtido incubando-se as amostras por 1 hora no protein blocking solution (Kit Reveal Spring, Bioscience, Pleasanton, California, EUA) a temperatura ambiente.

A incubação com os anticorpos primários procedeu-se overnight a $4 \stackrel{\circ}{\circ}$, em câmara úmida, utilizando-se os seguintes anticorpos: anticorpo policlonal, lgG de cabraanti-IL-17BR de camundongo (R\&D Systems, Minneapolis, MN, EUA; diluição 1:10 em TBS) e anticorpo policlonal, IgG de coelho anti-IL-25 de camundongo (Merck-Millipore, Darmstadt, Alemanha; diluição 1:50 em TBS).

Anticorpos secundários biotinilados espécie-específicos foram aplicados por 1 hora a temperatura ambiente em câmara úmida e a imunorreatividade visualizada utilizando-se o sistema estreptoavidina conjugado a peroxidase, por 1 hora (Sigma Chemical Co. Saint Louis, MI, USA; diluição 1:100 em TBS). Como anticorpos secundários foram utilizados os anticorpos $\lg \mathrm{G}$ de coelho anti-cabra biotinilado (Vector Laboratories Inc., Burlingame, CA, USA, 1:100 em TBS) para o receptor e o anticorpo IgG de cabra anti-coelho biotinilado (20 $\mu$; Anti-Rabbit HRP DAB Detection, Bioscience, Pleasanton, California, EUA, $20 \mu \mathrm{l}$ ) para IL-25. A atividade enzimática foi revelada utilizando-se o kit SIGMAFAST ${ }^{\text {тм }}$ 3,3'- diaminobenzidine (Sigma) e os núcleos contracorados com hematoxilina de Mayer e diferenciados com solução saturada de cloreto de lítio.

Grupos controle negativos seguiram protocolo similar acima descrito, porém incubados apenas com protein blocking solution (Kit Reveal, Spring Bioscience, Pleasanton, California, EUA) sem adição do anticorpo primário. As amostras foram 
visualizadas e fotografadas em microscópio de luz acoplado a uma câmera digital Nikon Coolpix 5000 (Nikon Corporation, Tokyo, Japão).

\subsection{Análise Estatística}

A análise estatística foi realizada utilizando o teste One-way ANOVA, seguido pelo pós-teste de Turkey. Os resultados foram expressos pela média \pm erro padrão médio. Diferenças foram consideradas significativas quando $p<0.05$. Todos os resultados foram comparados utilizando Prism versão 5.00 (GraphPad Software Inc.). 
5 RESULTADOS 


\subsection{Análise da Expressão Gênica de IL-25 e seu Ligante IL-17BR em Tecidos Placentários durante a Gestação em Camundongos}

A análise da expressão gênica de IL-25 foi inicialmente realizada em sítios de implantação nos dias 5,5, 7,5 e 10,5 de gestação, os quais continham tecidos de origem tanto fetal quanto materna com todos seus componentes glandulares e estromais, assim como componentes vasculares e elementos figurados do sangue local. Essa primeira avaliação demonstrou valores baixos de expressão da citocina durante os dias 5,5 e 7,5de gestação, com valores maiores e significativos $(p \leq 0,01)$ no dia 10,5 de gestação (Fig. 2).

\section{Sítio de Implantação}

IL-25

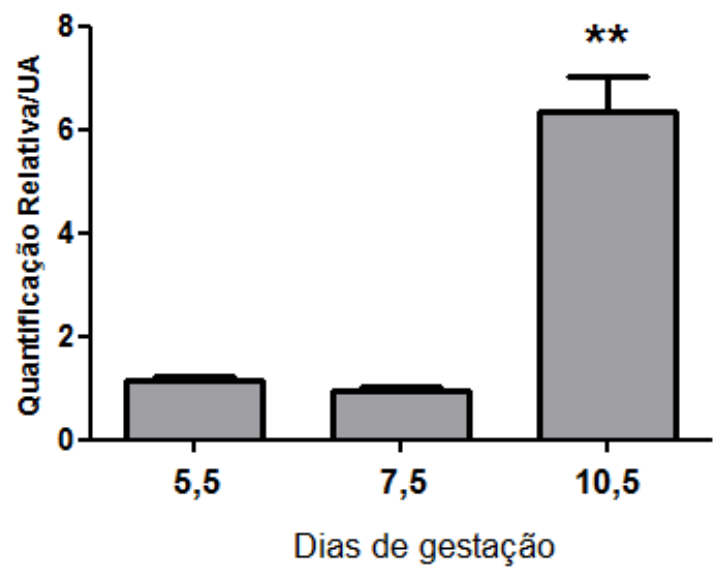

Figura 2 - Padrão de expressão gênica da Interleucina 25 em sítios de implantação. Níveis de RNAm de IL-25 em sítios de implantação nos dias 5,5, 7,5 e 10,5 de gestação. A análise da expressão gênica foi realizada por qRT-PCR, utilizando como gene endógeno o YWHAZ. Os dados foram avaliados pelo teste ANOVA seguidos de pós teste de Turkey e estão expressos como média \pm erro padrão. $\mathrm{n}=6$. ${ }^{* *} \mathrm{p} \leq 0,01$.

A detecção do aumento dos índices de IL-25 em um momento pós-implantacional conduziu a uma segunda etapa de ensaios, em que a expressão gênica de IL-25 e seu receptor IL-17BR e IL-17AR nos compartimentos materno e fetal que compõe a placenta foram analisadas de forma individual entre os dias 10,5 e 19,5 de gestação.

Os índices do RNAm da IL-25 na região fetal da placenta mostraram valores significativamente maiores $(p<0,001)$ nos dias 13,5 e 16,5 de gestação em relação 
aos dias 10,5 e 19,5 de gestação (Fig. 3A). Os níveis de expressão de IL-25 no dia 13,5 também foram significativamente diferentes em relação ao dia 16,5 de gestação ( $p<0,001)$. Na decídua, porção materna da placenta, as taxas de expressão de IL-25 foram relevantemente maiores no dia 16,5 de gestação ( $p \leq 0,001)$, embora estes valores tenham sido muito inferiores aos observados na porção fetal (Fig. 3C).

$\mathrm{Na}$ avaliação da expressão dos receptores IL-17B/A R, observou-se níveis altos de RNAm para ambos na porção fetal da placenta (Fig. 3B). A expressão de IL-17BR atingiu valores máximos e significativamente diferentes de todos os demais ( $p<0,001$ ) nos dias 13,5 e 16,5 de gestação (Fig. 3B), enquanto que a expressão de IL-17AR foi relevantemente mais alta apenas no dia 16,5 de gestação $(p<0,01)$. Os valores observados para o receptor IL-17B no dia 19,5 de gestação foi significativamente mais baixo em relação aos demais $(p<0,01)$.

No compartimento materno (Fig. 3D) os níveis de expressão do receptor IL-17BR foram mais baixos do que os observados na porção fetal, sem diferenças estatísticas entre os dias analisados. O receptor IL-17AR, mostrou aumento significativo nos dias 13,5 e 16,5 de gestação $(p<0,01)$ em relação ao dia 10 de gestação. No dia 19,5, o compartimento materno não foi representado porque nessa fase a decídua já sofreu completa involução. 
A)

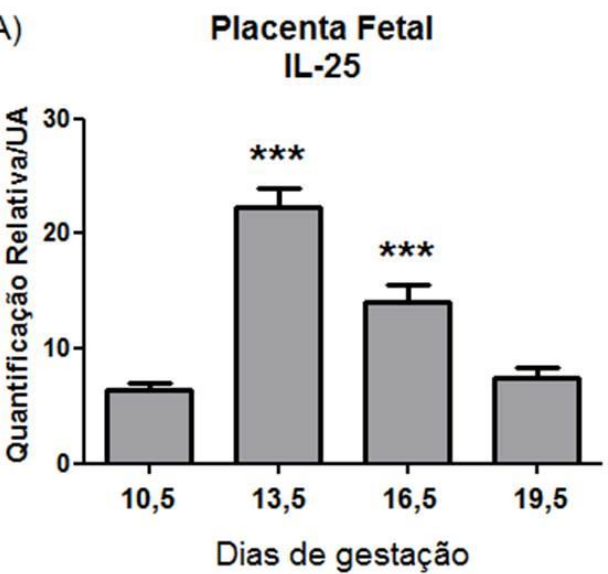

C)
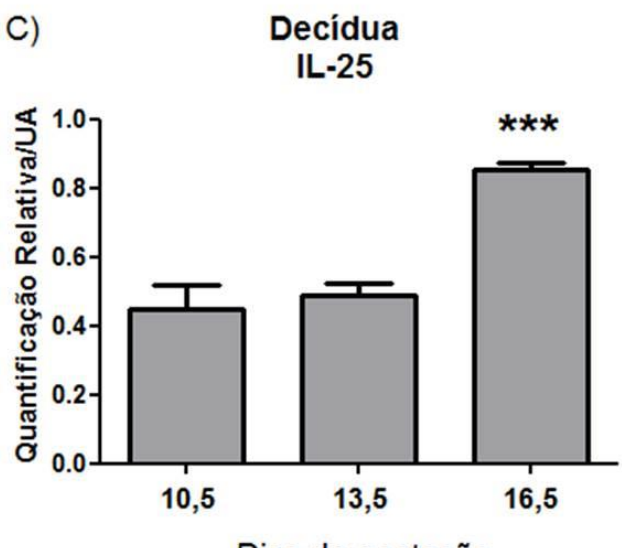

Dias de gestação
B) Placenta Fetal

IL-17BR/AR

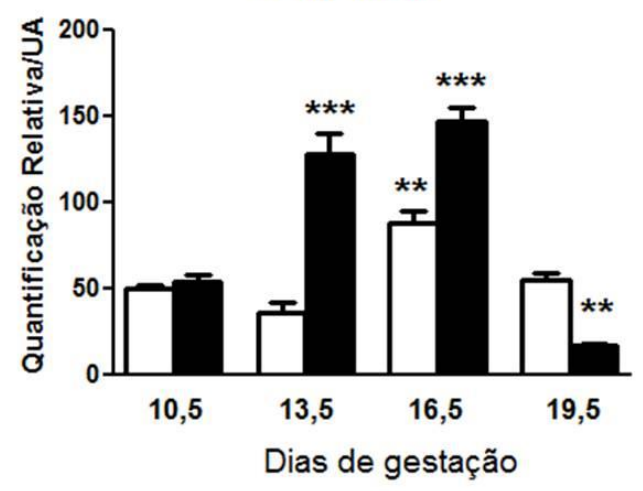

D) Decídua

IL-17BRIAR

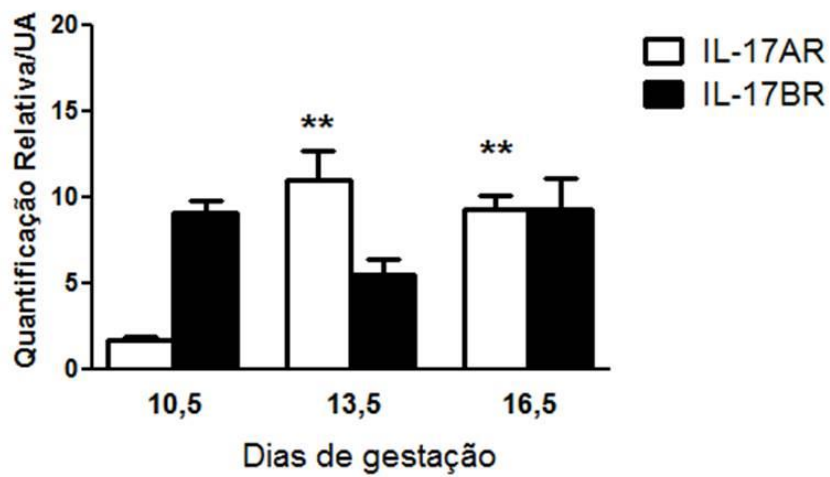

Figura 3 - Expressão gênica da Interleucina 25 e do receptor IL-17A/B em placentas de camundongo. Gráficos representativos dos níveis de RNAm de IL-25, IL-17BR e IL-17AR na porção fetal $(A, B)$ e materna $(C, D)$ da placenta de camundongos nos dias $10,5,13,5,16,5$ e 19,5 de gestação. $A$ análise da expressão gênica foi realizada por qRT-PCR, utilizando como gene endógeno o YWHAZ. Os valores deciduais para o dia 19,5 de gestação estão ausentes porque nessa fase já houve completa involução dessa estrutura. Os dados foram avaliados pelo teste ANOVA seguidos de pós teste de Turkeye estão expressos pela média \pm erro padrão. $(n=6)$. Todos os dados foram estatisticamente comparados em relação ao dia 10,5 de gestação dentro do mesmo fator estudado. $n=6$, ${ }^{* *} p \leq 0,01,{ }^{* * *} p \leq 0,001$.

\subsection{Imunolocalização da Citocina IL-25 e do seu Receptor IL-17BR na Interface Materno-Fetal em Camundongos}

A análise das reações para a imunolocalização de IL-25 e seu receptor IL-17BR mostrou reatividade para ambos na interface materno-fetal nos dias 10,5, 13,5 e 16,5 de gestação, mas não nas placentas de 19,5 dias de gestação (Figs. 4-7). 
No dia 10,5 de gestação, reatividade do anticorpo anti-IL-25 foi observada principalmente na região fetal da placenta: região do labirinto e zona juncional (Fig. 4A). Reatividade foi observada nas células do labirinto, do espongiotrofoblasto (Fig. 4B) e nas células trofoblásticas gigantes (Fig. 4D). Na decídua a reação foi fracamente observada. Na glândula metrial, células fortemente positivas foram encontradas; a localização e características morfológicas dessas células eram compatíveis células uterinas NK e leucócitos mononucleares (Fig. 4C). Preparados histológicos controle da reação imunohistoquímica não apresentaram qualquer reatividade (Figs. 4E-F).
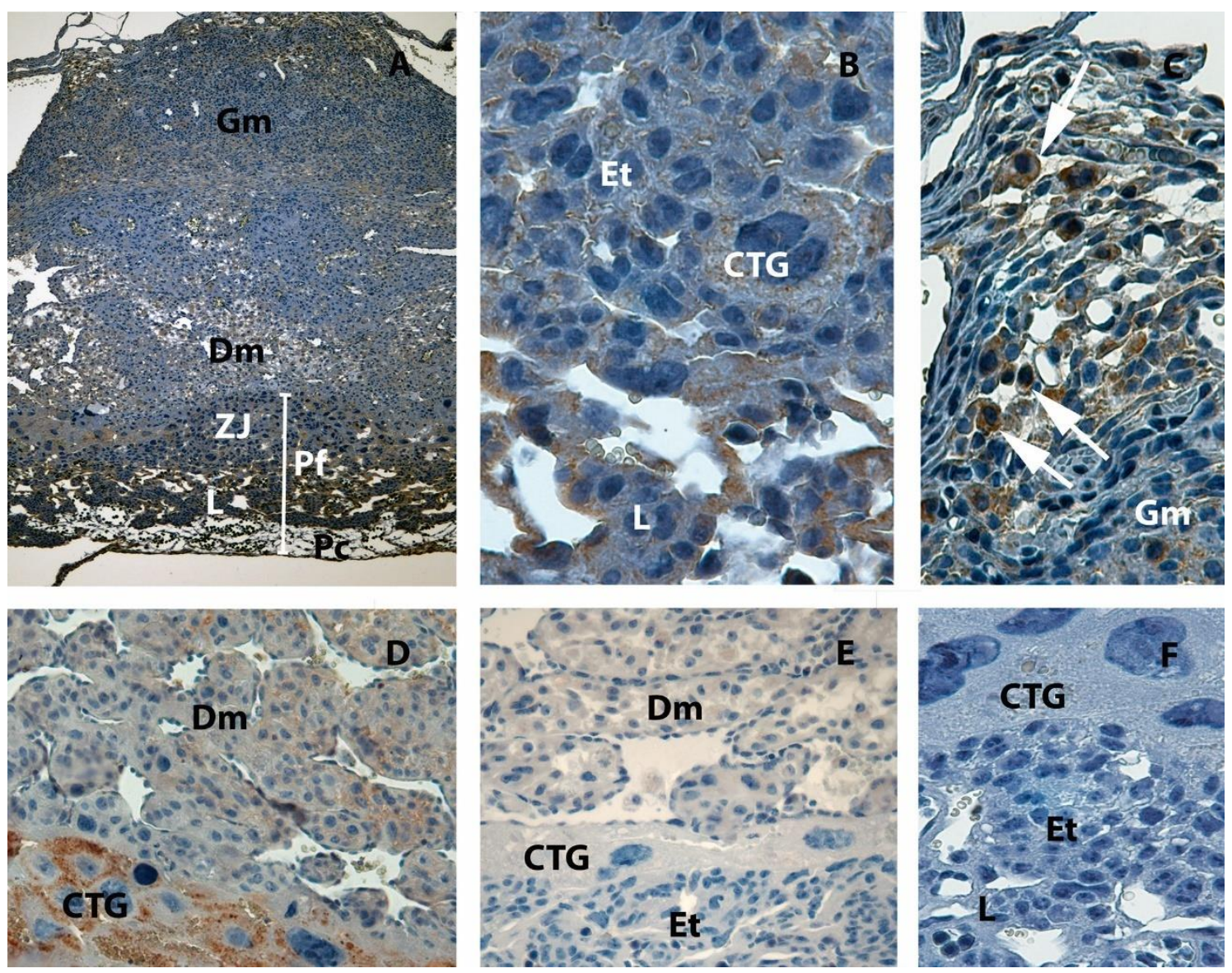

Figura 4 - Imunolocalização da IL-25 na interface materno-fetal no dia 10,5 de gestação. (A-B) Imunolocalização de IL-25 na porção fetal (Pf) da placenta. Notar a presença de reatividade (coloração marron) principalmente na região do labirinto (L), do espongiotrofoblasto $(E t) e$ em células gigantes (B,D, CTG) da zona juncional (ZJ). (D) Na porção materna, células presentes na decídua mesometrial (Dm) mostraram fraca reatividade a citocina. (C) Notar entretanto a presença de células morfologicamente semelhantes a células uterinas NK e leucócitos (setas) fortemente coradas na região da glândula metrial. Controles negativos em que $o$ anticorpo primário foi omitido da reação estão representados nas Figuras $E$ e $F$. Imunoperoxidase. Aumentos (A) 5X; (B) 20X; (C) 10X; (D-F) 20X. 
A imunolocalização do receptor IL-17BR no dia 10,5 da gestação, revelou forte reatividade na decídua (Fig. 5B-D e detalhe na figura 5B). Notar no detalhe da Figura 5B que a marcação do receptor predomina nas regiões periféricas das células deciduais. Leucócitos reativos também foram observados nos compartimentos intravasculares (dados não mostrados). Controles negativos da reação imunohistoquímica não apresentou reatividade (Fig. 5A).
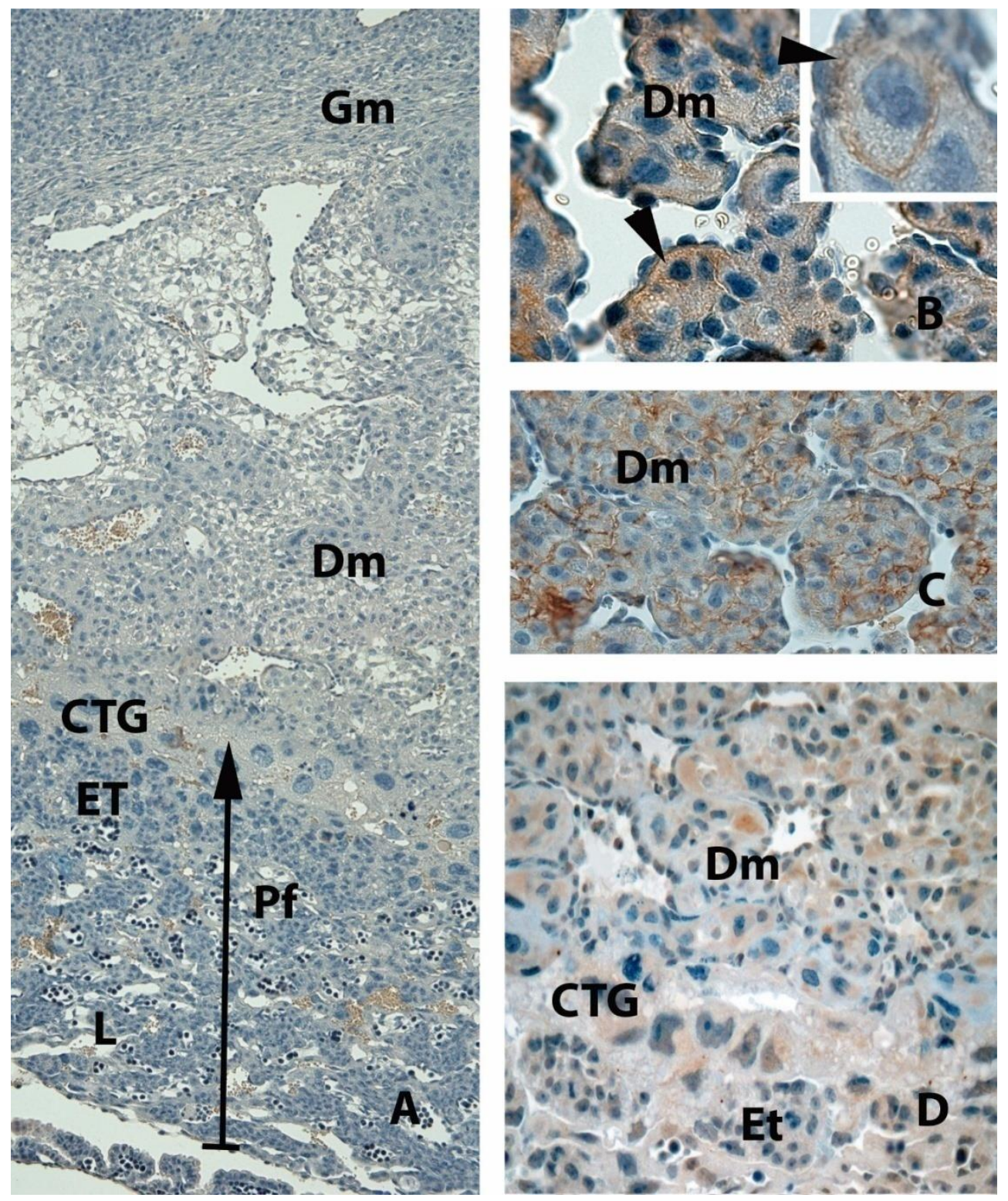

Figura 5 - Imunolocalização do receptor IL-17B na interface materno-fetal no dia 10,5 de gestação. (A-D) Células deciduais IL-17BR fortemente reativas (B, seta) predominaram na interface materno-fetal. Notar no detalhe da figura $B$ a localização periférica da imunomarcação (seta). (D) Células trofoblásticas gigantes (CTG) do espongiotrofoblasto (Et) na Zona Juncional apresentaram fraca coloração pelo anticorpo anti IL-17BR. (A) Controle negativo em que o anticorpo primário foi omitido da reação. Imunoperoxidase. Aumentos (A) 5X; (B) 40X; (C-D) 20X. Detalhe da figura B, 60X. 
Nos dias 13,5 e 16,5 de gestação a imunoreatividade de IL-25 e IL-17BR mostrou um padrão de localização e intensidade bastante similar na interface materno-fetal (Fig. 6). Na região fetal da placenta (Fig. 6C-D), em ambos os períodos gestacionais houve intensa marcação para IL-25 na região do labirinto, mas não na região do espongiotrofoblasto. Células IL-25 reativas também foram observadas na região da decídua mesometrial (Fig. 6E) e da glândula metrial (Fig. 6B).

As células da região fetal da placenta, por sua vez, mostraram-se fracamente reativas ao anticorpo anti-IL-17BR (Fig. 6F), ao contrário da intensa reatividade observada nas células presentes na decídua e na glândula metrial (Fig. 6G), onde células leucocitárias no interstício do estroma ou intravasculares foram frequentemente encontradas (Fig. 6H). Controles negativos da reação imunohistoquímica não apresentou reatividade (Fig. 6A). 

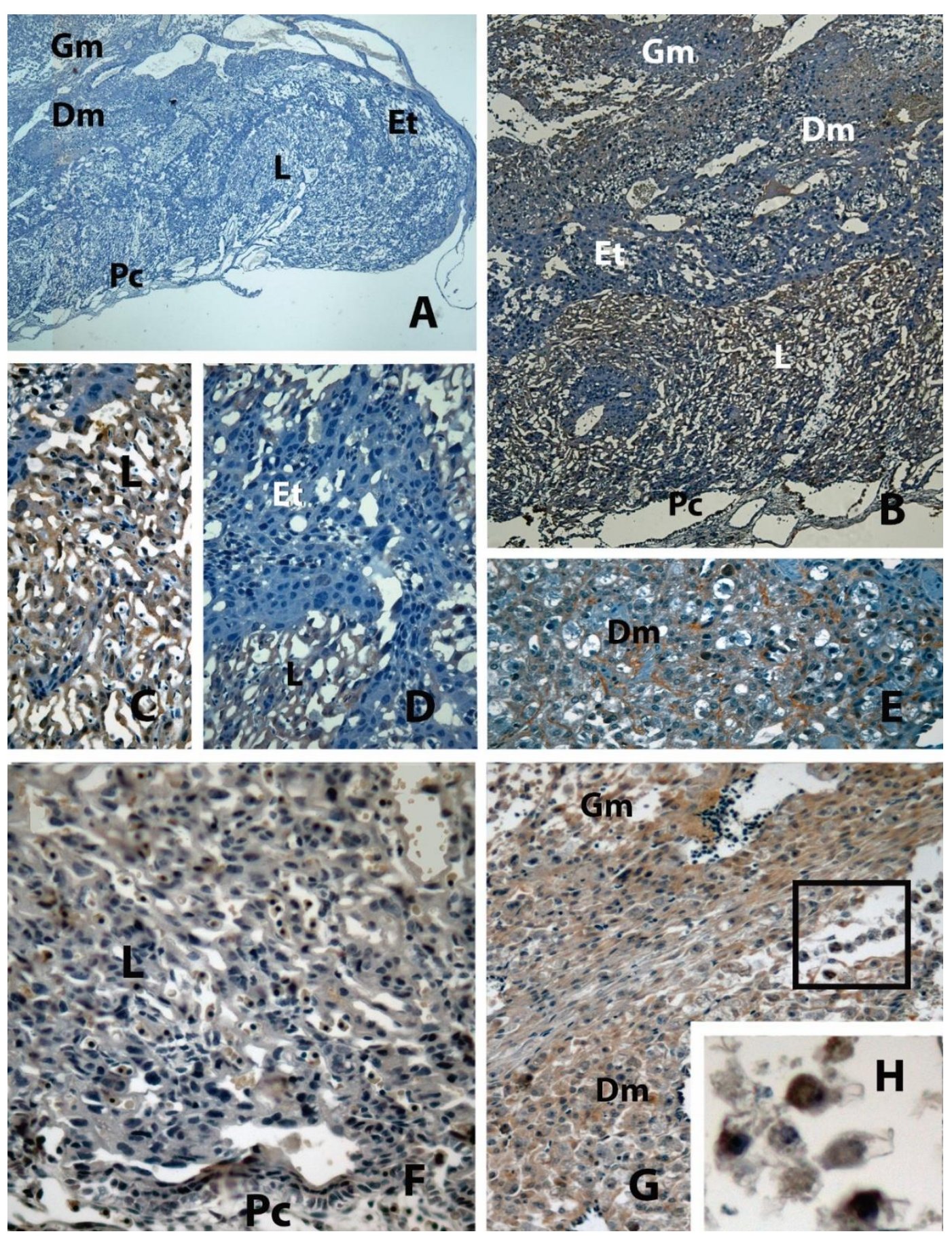

Figura 6 - Imunolocalização da IL-25 e do receptor IL-17B na interface materno-fetal nos dias 13,5 (A-E) e 16,5 de gestação (F-H). A imunolocalização de IL-25 na porção fetal da placenta $(A-D)$ mostra células reativas (coloração marrom) principalmente na região do labirinto (L), mas não na região do espongiotrofoblasto (D). Na porção materna, células presentes na decídua $(D, D m)$ e na glândula metrial $(B, G m)$ foram reativas para a citocina. (G) Células $I L-17 B R$ reativas $(\boldsymbol{F}-\boldsymbol{H})$ foram imunolocalizadas principalmente na porção materna da placenta, na região das células deciduais mesometriais $(D m)$ e da glândula metrial $(\mathrm{Gm})$. Leucócitos intravasculares reativos estão destacados no detalhe, na Figura H. Na região do labirinto (Fig. $F, L$ ) poucas células foram reativas ao anticorpo. (A) Controle negativo em que o anticorpo primário foi omitido da reação. Imunoperoxidase. Aumentos (A) 5X; (B) 10X; (C-G) 20X; (H) 60X. 
No dia 19,5 de gestação, a imunolocalização de IL-25 e IL-17BR não foi observada reatividade em nenhuma das regiões da interface materno-fetal (Fig. 7).
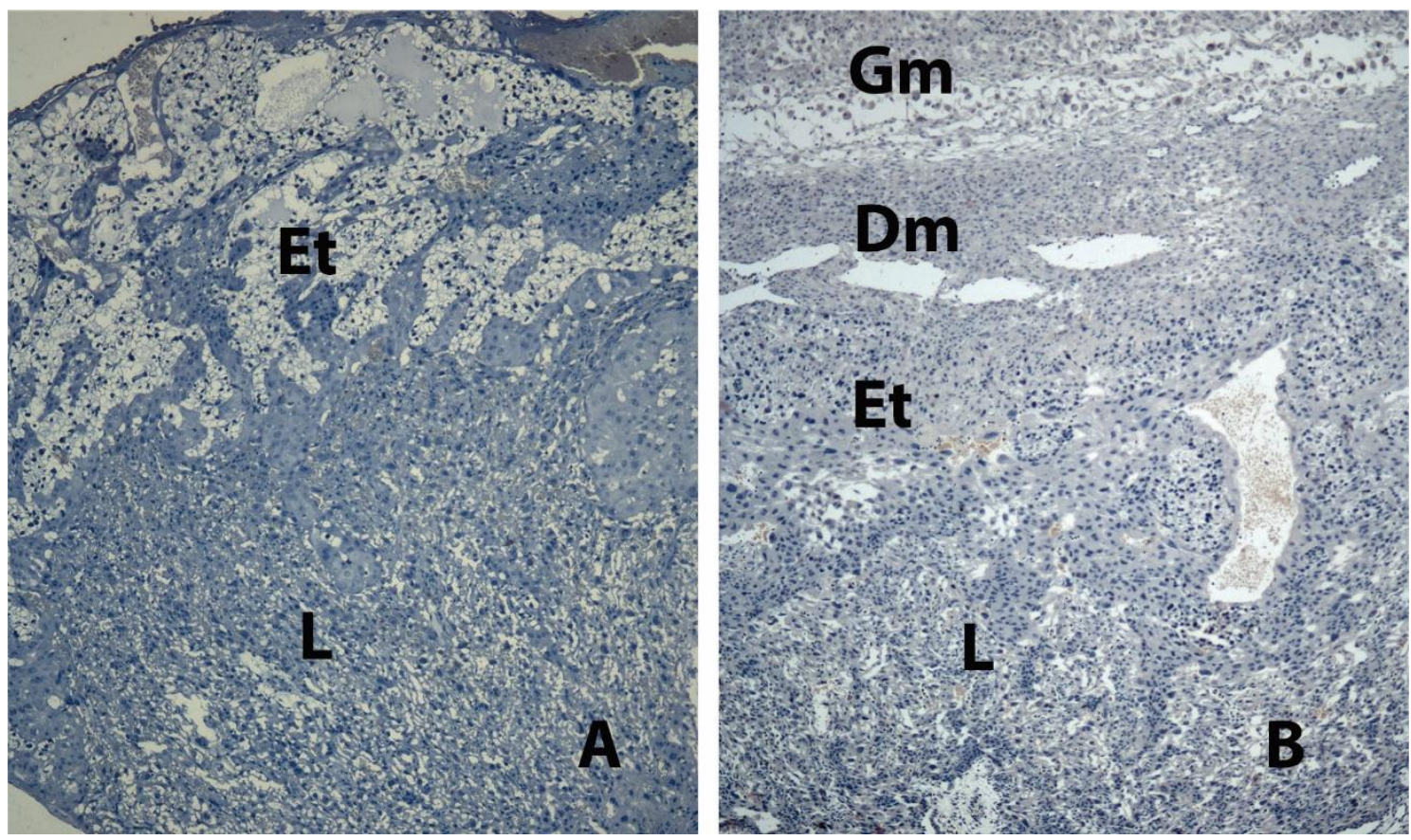

Figura 7 - Imunolocalização da IL-25 e do receptor IL-17B na interface materno-fetal no dia 19,5 de gestação. Notar a ausência de reatividade para IL-25 (A) e do seu receptor IL-17B (B). Imunoperoxidase. Aumentos (A-B) 10X.

\subsection{Níveis de IL-25 e do Receptor IL-17B na Interface Materno-Fetal}

Para avaliar os níveis da citocina IL-25 e seu ligante o IL-17BR, no ambiente placentário, amostras de placentas coletadas nos dias 10,5, 13,5, 16,5 e 19,5 de gestação foram analisadas por citometria de fluxo (porção fetal e materna: decídua).

As células isoladas da porção fetal da placenta apresentaram aumento no número de células que expressam IL-25 e seu ligante IL-17BR a partir do dia 10,5, atingindo ambos, um pico máximo no dia 16,5 de gestação (Fig. 8A-B e Fig.16 do material suplementar, Apêndice A).

Os valores observados para o dia 13,5 e 16,5 foram significativamente maiores $(p<0,001)$ do observado no dia 10.5 de gestação. No dia 19,5 de gestação, não foi possível detectar níveis de IL-25 ou de seu ligante IL-17BR nas células analisadas (Fig.8). 

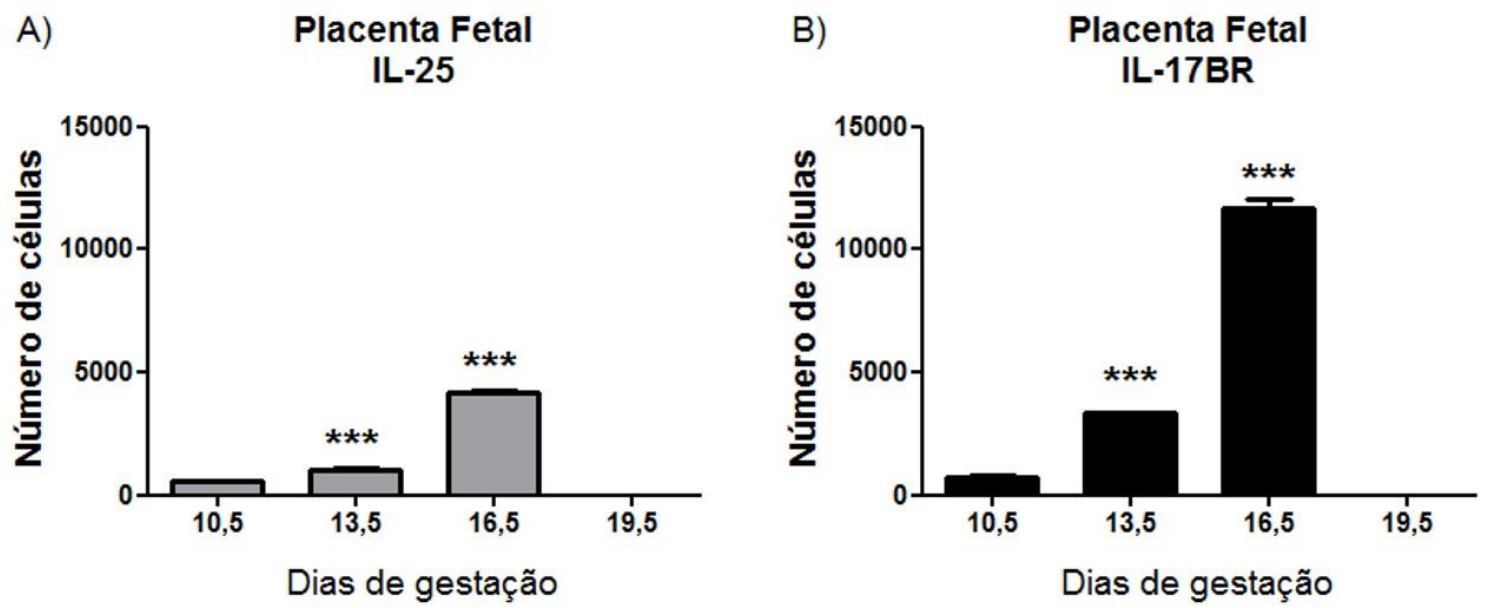

Figura 8 - Avaliação das populações de células isoladas da região fetal da placenta quanto a produção da citocina IL-25 (A) e seu ligante IL-17BR (B) nos dias 10,5, 13,5, 16,5 e 19,5 de gestação por citometria de fluxo. A análise foi realizada com o auxílio do software FlowJo (Tree Star, INc., Ashland, OR, EUA) a partir de 100.000 eventos no Citômetro de Fluxo BD Canto ${ }^{\mathrm{TM}}$. Os dados estão expressos como média \pm erro padrão e foram avaliados pelo teste ANOVA seguidos de pós teste de Turkey em relação ao dia 10,5 de gestação para cada grupo. $(n=6) . \quad{ }^{* * *} p \leq 0,001$.

Para a caracterização das células que poderiam contribuir para a produção de IL-25 ou serem responsivas à essa citocina no ambiente placentário, os níveis de citocina e seu ligante foram analisados tendo como referência a expressão de citoqueratina 8, marcador de células trofoblásticas e do marcador leucocitário, CD45. Como demonstrado na Figura 9, na fase de maior presença da citocina e do seu receptor - dia 16,5 de gestação - as células trofoblásticas da porção fetal da placenta contribuem de forma mais expressiva para a produção de IL-25 (42\% das células IL-25+) quando comparadas aos leucócitos (4\% das células IL-25+, p<0,001) (Fig. 9B). Para o receptor - IL-17BR - observou-se, entretanto, maior número de células reativas na população leucocitária CD45 positivas $(22 \%$ das células IL-17BR+, $\mathrm{p}<0,001$ ) do que nas populações de células trofoblásticas (Fig. 9C e Fig.17 do material suplementar, Apêndice B). 


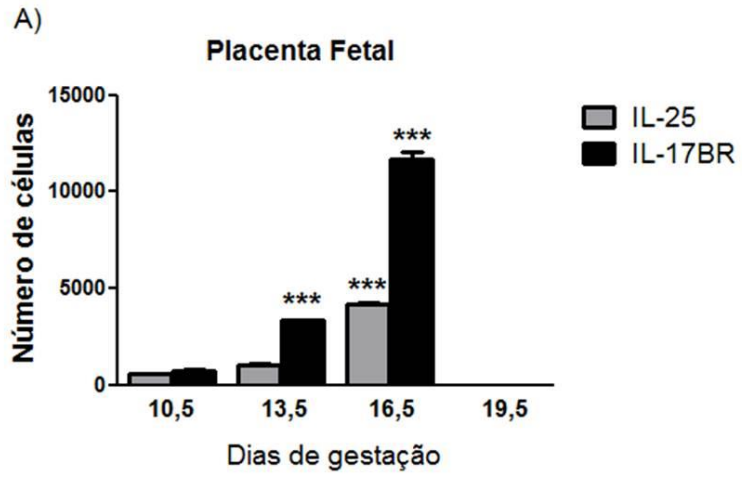

C)

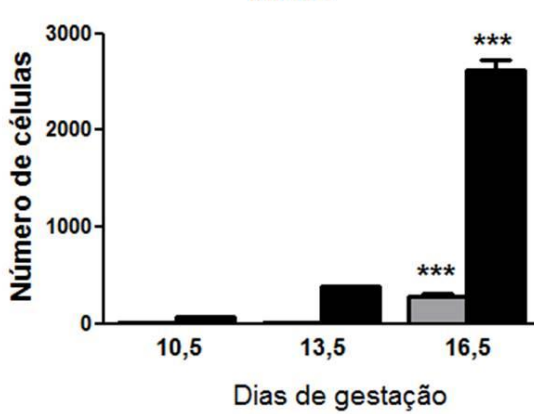

B)

Placenta Fetal $\mathrm{CK}+$

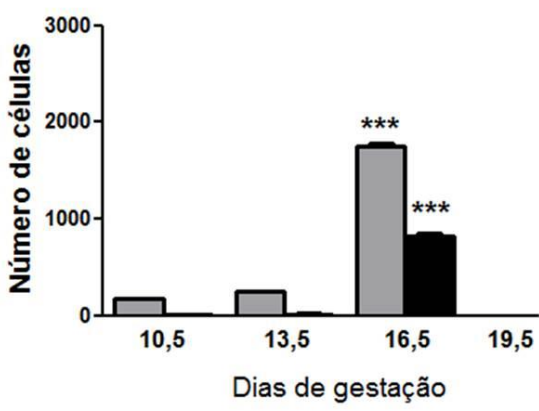

Figura 9 - Avaliação da populações de células trofoblásticas citoqueratina positivas (B, CK+) e leucocitária (C, CD45+) isoladas da região fetal da placenta quanto a produção da citocina IL-25 e seu ligante IL-17BR nos dias 10,5, 13,5, 16,5 e 19,5 de gestação por citometria de fluxo. A Figura A sumariza os valores encontrados para as análises globais de células da região fetal da placenta. As arnálises foram realizadas com o software FlowJo (Tree Star, INc., Ashland, OR, EUA) com 100.000 eventos adquiridos no Citômetro de fluxo BD Canto ${ }^{\mathrm{TM}}$. Os dados estão expressos como média \pm erro padrão e foram avaliados pelo teste ANOVA seguidos de pós teste de Turkey em relação ao dia 10,5 de gestação para cada grupo. $(n=6) .{ }^{* * *} p \leq 0,001$.

Ao avaliarmos a porção materna da placenta verificou-se que o número de células expressando a citocina e seu receptor também aumentaram significativamente nos dias 13,5 e 16,5 de gestação (Fig. 10 a e Fig.18 do material suplementar, Apêndece C). Esses níveis, entretanto, foram mais baixos do que os encontrados na porção fetal da placenta. O nível do receptor IL-17BR na decídua foi estatisticamente maior no dia 16,5 de gestação quando comparado aos demais períodos estudados $(\mathrm{p}<0,001$, Fig. 10B). 
A)

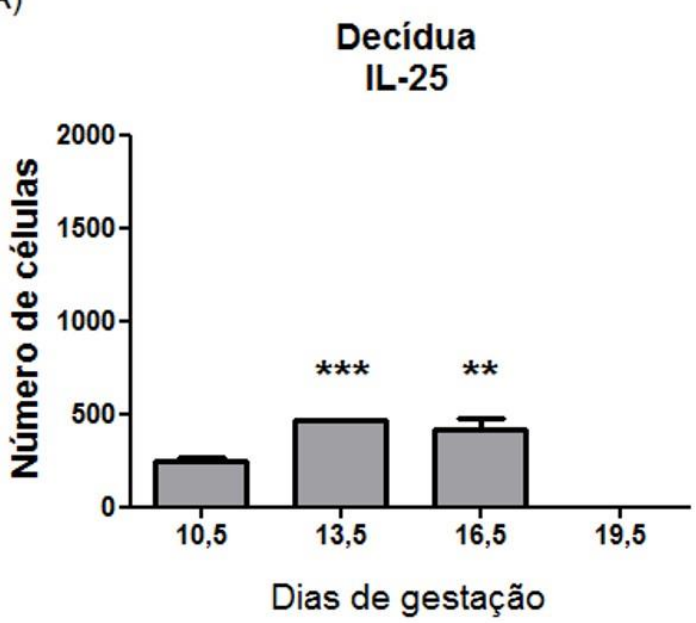

B)

Decídua

Decídua
IL-17BR

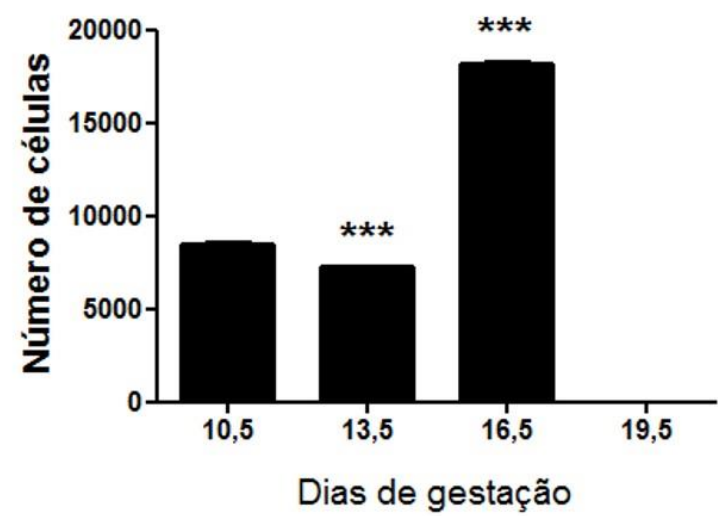

Figura 10 - Avaliação das populações de células isoladas da porção materna da placenta (decídua) quanto a produção da citocina IL-25 (A) e seu ligante IL-17BR (B) nos dias $10,5,13,5,16,5$ e 19,5 de gestação, por citometria de fluxo. As análises foram realizadas com o software FlowJo (Tree Star, INc., Ashland, OR, EUA) com 100.000 eventos adquiridos no Citômetro de fluxo BD Canto $^{\mathrm{TM}}$. Os dados estão expressos como média \pm erro padrão e foram avaliados pelo teste ANOVA seguidos de pós teste de Turkey em relação ao dia 10,5 de gestação para cada grupo. $(n=6) .{ }^{* *} p \leq 0,01$ e ${ }^{* * *} p \leq$ 0,001 .

No compartimento materno, de modo geral, foi flagrante a expressão do receptor em detrimento da citocina (Fig. 11A). Utilizando-se do marcador CD45, também foi possível identificar a população leucocitária que participa da produção de IL-25 e IL-17BR na região decidual. Como pode ser observado na Figura 11, os leucócitos expressaram predominantemente o receptor IL-17BR (17\% do total de células IL-17BR+) no dia 10,5 de gestação (Fig.19 do material suplementar, Apêndice D). A população leucocitária contribuiu de forma mais expressiva para os níveis totais de IL-17BR no dia 10,5 de gestação (Fig. 11B). O número de células envolvidas na expressão do receptor decresceu significativamente nos dias subseqüentes da gestação $(p<0,001)$.

A expressão de IL-25 no total de células presentes na decídua foi muito baixo (Fig. 11A, cerca de 0,25\%) e desse total apenas cerca de 7\% correspondeu às células CD45+ expressando IL-25 (Fig. 11B e Fig.19 do material suplementar, Apêndice D) em todos os dias da gestação estudados. 

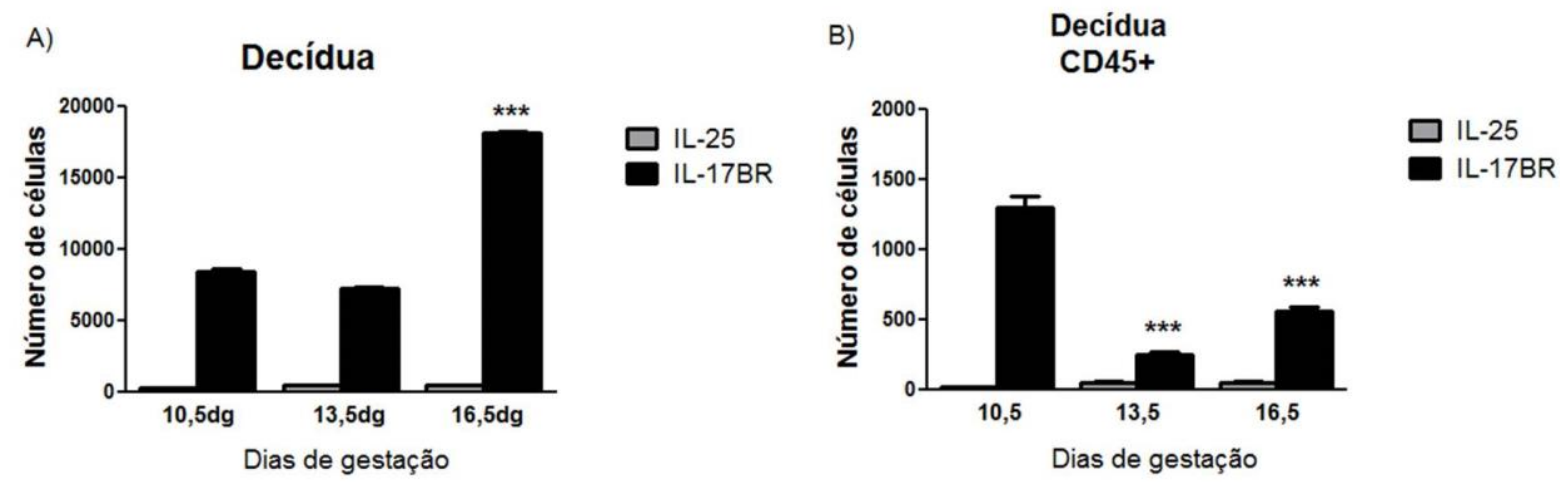

Figura 11 - Avaliação das populações de células totais presentes na decidua $(A)$ e de células leucocitárias ( $B, C D 45+)$ isoladas da região materna da placenta quanto a produção da citocina IL-25 e seu ligante IL-17BR, nos dias 10,5, 13,5, 16,5 e 19,5 de gestação, por citometria de fluxo. A Figura $\boldsymbol{A}$ sumariza os valores encontrados para as análises globais de células da região materna da placenta. As análises foram realizadas com o software FlowJo (Tree Star, INc., Ashland, OR, EUA) com 100.000 eventos adquiridos no Citômetro de fluxo BD Canto ${ }^{\mathrm{TM}}$. Os dados estão expressos como média \pm erro padrão e foram avaliados pelo teste ANOVA seguidos de pós teste de Turkey em relação ao dia 10,5 de gestação para cada grupo. $(n=6)$. ${ }^{* * *} p \leq 0,001$.

A análise comparativa entre os compartimentos placentários mostra nitidamente a prevalência de produção de IL-25 na placenta fetal e a do receptor IL-17BR no compartimento materno (Fig. 12). 


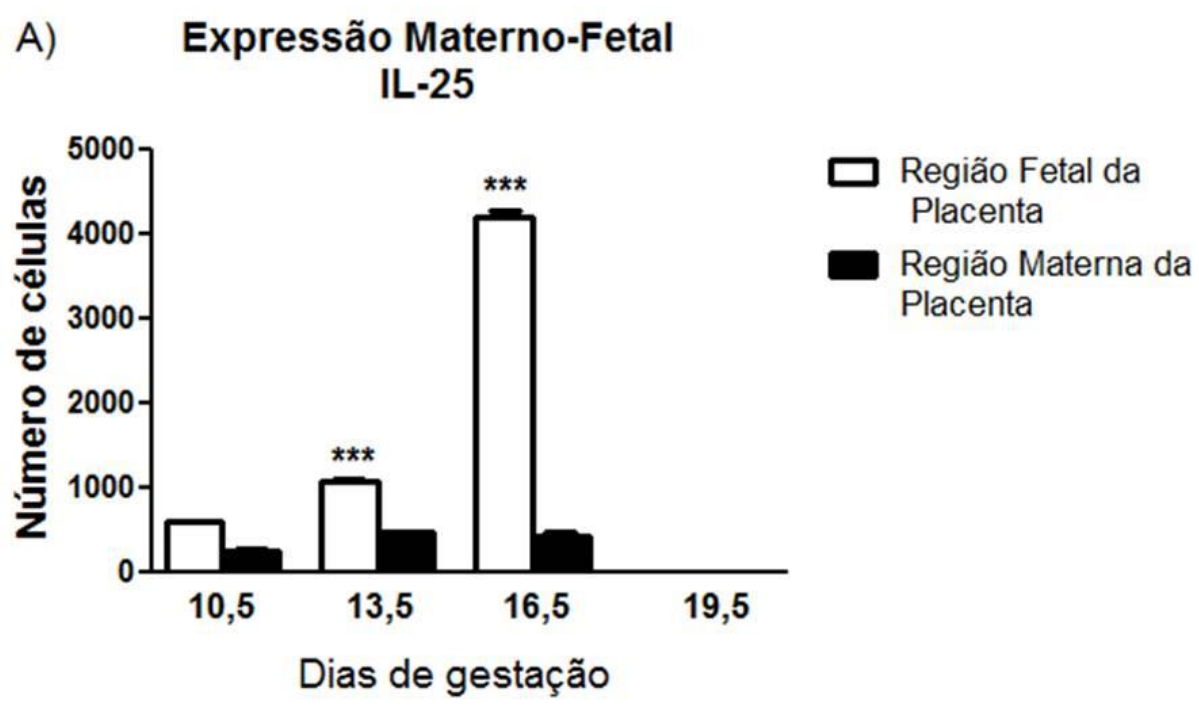

B) Expressão Materno-Fetal

\section{IL-17BR}

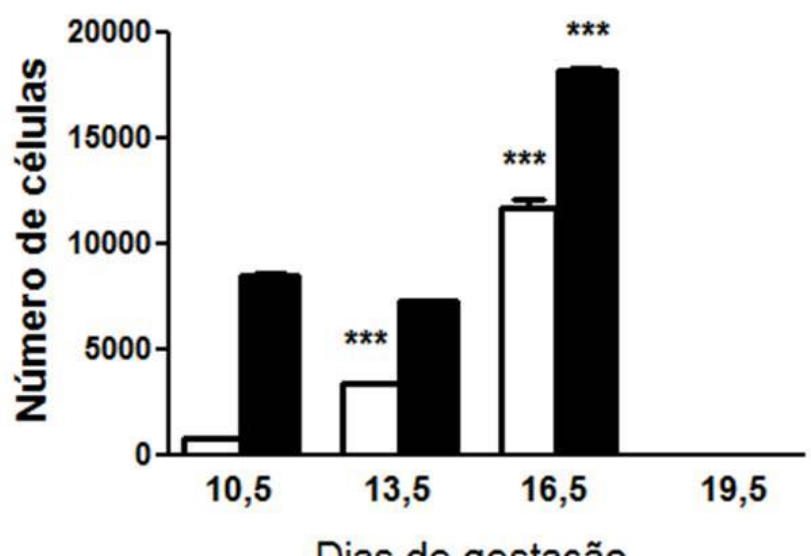

$\square$ Região Fetal da Placenta

Região Materna da Placenta

Figura 12 - Avaliação das populações de células totais isoladas da região materna (colunas vazadas) e fetal (colunas pretas) da placenta quanto a produção da citocina IL-25 (A) e seu ligante IL-17BR (B), nos dias 10,5, 13,5, 16,5 e 19,5 de gestação, por citometria de fluxo.As análises foram realizadas com o software FlowJo (Tree Star, INc., Ashland, OR, EUA) com 100.000 eventos adquiridos no Citômetro de fluxo BD Canto ${ }^{\mathrm{TM}}$. Os dados estão expressos como média \pm erro padrão e foram avaliados pelo teste ANOVA seguidos de pós teste de Turkey em relação ao dia 10,5 de gestação para cada grupo. $(n=6) .{ }^{* * *} p \leq 0,001$.

Sendo a placenta de camundongos hemocorial, existe um íntimo contato entre o compartimento sanguíneo e as células placentárias fetais. Desta forma, foi também avaliado no sangue materno, que percola a placenta fetal, os níveis IL-25 e do receptor IL-17BR nos dias 10,5 a 19,5 de gestação. 
As células periféricas mononucleares do sangue foram isoladas (CMNs) e analisadas por citometria de fluxo. Células expressando a citocina IL-25 foram encontradas em todos os períodos estudados, embora em níveis baixos. Além disso, ao contrário do observado no tecido placentário, no sangue materno a produção da citocina IL-25 no dia 16,5 foi menor do que nos dias 10,5 e 13,5 de gestação (Fig. 13A, $p<0,001)$. Em relação a IL-17BR, houve relevante aumento $(p<0,001)$ no número de células expressando o ligante nos dias 13,5 e 16,5 de gestação, sendo no dia 16,5 de gestação esses valores ainda mais altos (Fig. 13B e Fig.20 do material suplementar, Apêndice $E, p<0,001$ ).
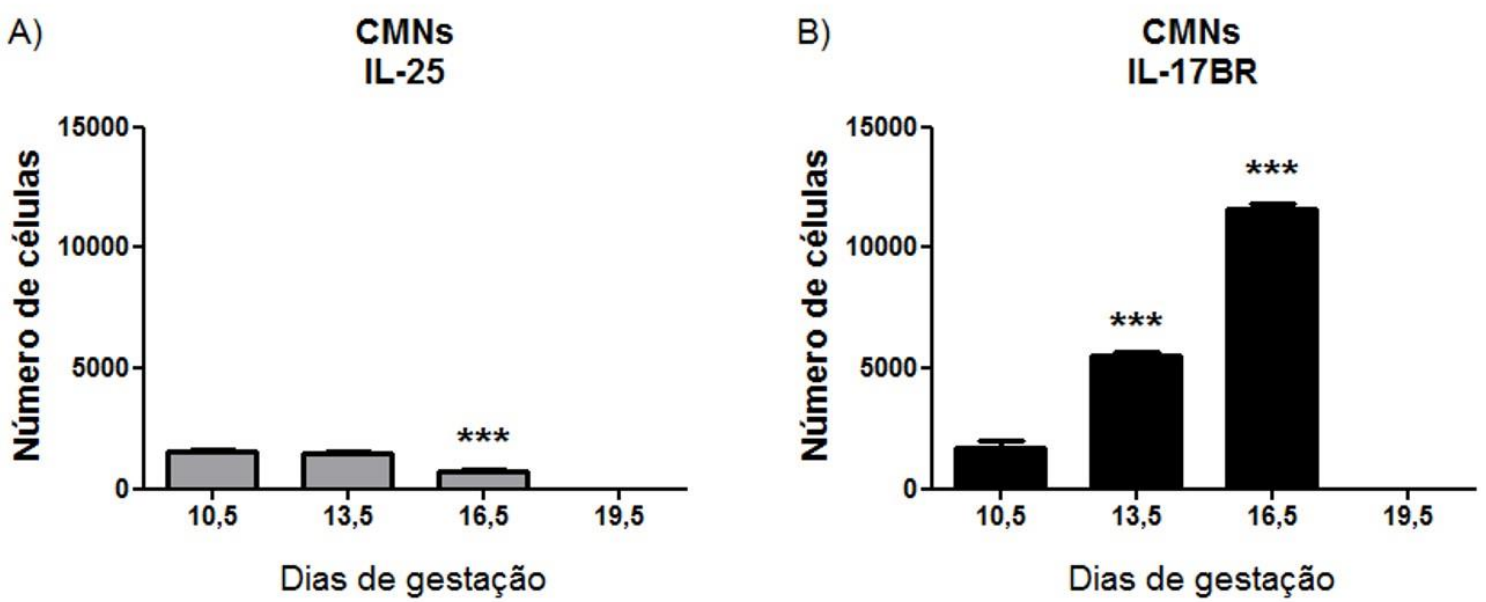

Figura 13 - Avaliação da população de células mononucleares isoladas do sangue materno quanto a produção da citocina IL-25 (A) e seu ligante IL-17BR (B), nos dias 10,5, $13,5,16,5$ e 19,5 de gestação, por citometria de fluxo. As análises foram realizadas com o software FlowJo (Tree Star, INc., Ashland, OR, EUA) com 100.000 eventos adquiridos no Citômetro de fluxo BD Canto ${ }^{\mathrm{TM}}$. Os dados estão expressos como média \pm erro padrão e foram avaliados pelo teste ANOVA seguidos de pós teste de Turkey em relação ao dia 10,5 de gestação para cada grupo. $(n=6)$. ${ }^{* * *} p \leq 0,001$.

$\mathrm{Na}$ análise global dos resultados nota-se que a produção de citocina é menor em relação ao receptor IL-17BR em todos os compartimentos que compõe a interface materno-fetal (placenta fetal, decídua e CMNs) em todos os períodos estudados (Fig. 14). 


\section{Expressão IL-25/IL-17BR Interface Materno-Fetal}

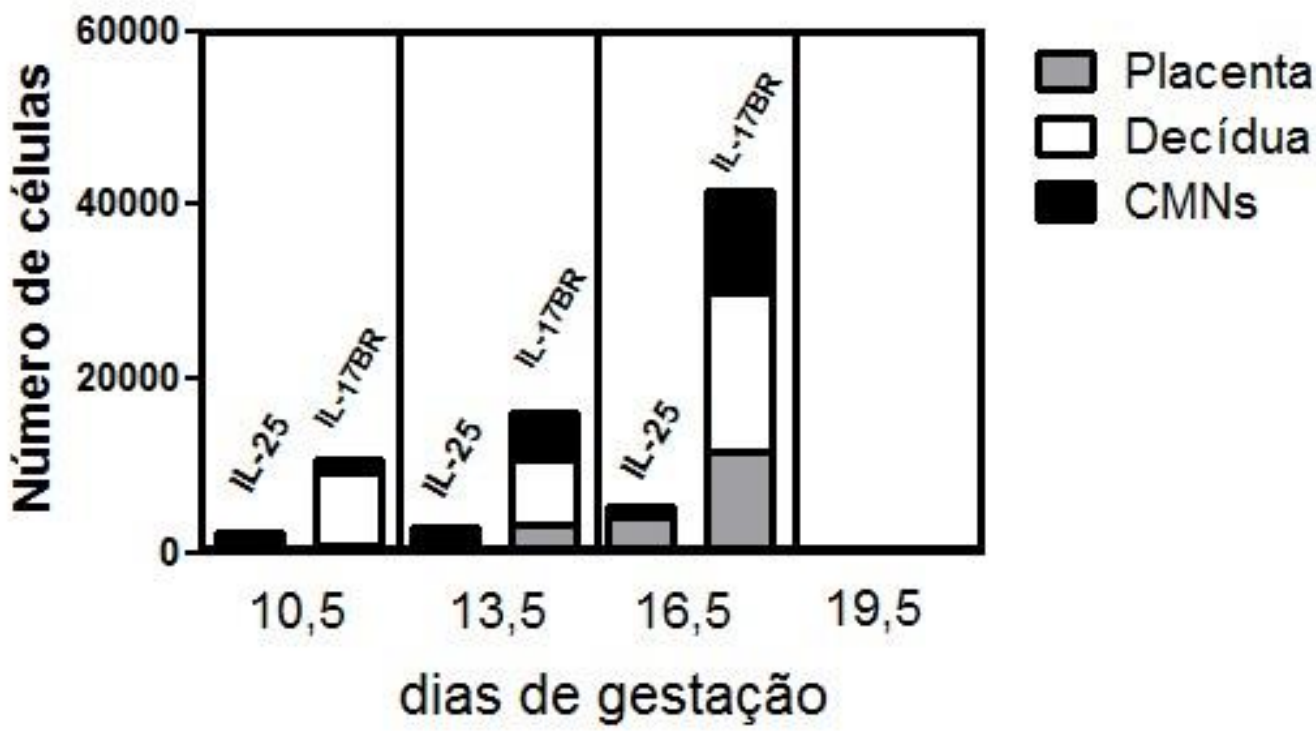

Figura 14 - Avaliação da produção da citocina IL-25 e seu ligante IL-17BR nos dias 10,5, 13,5, 16,5 e 19,5 de gestação, nos diferentes compartimentos que integram a interface materno-fetal, por citometria de fluxo.As análises foram realizadas com o software FlowJo (Tree Star, INc., Ashland, OR, EUA) com 100.000 eventos adquiridos no Citômetro de fluxo BD Canto $^{\mathrm{TM}}$. Os dados estão expressos como média \pm erro padrão e foram avaliados pelo teste ANOVA seguidos de pós teste de Turkey em relação ao dia 10,5 de gestação para cada grupo. $(n=6)$. ${ }^{* * *} p \leq 0,001$. 
6 DISCUSSÃO 
A Interleucina 25 pertence à família da interleucina 17, também conhecida como IL-17E, no entanto não compartilha funções biológicas comuns as outras isoformas (HURST et al., 2002). Ela foi inicialmente descrita como um fator associado a resposta imunológica do tipo Th2, ou seja, em respostas anti-inflamatórias, induzindo a expressão de IL-4, IL-5 e IL-13 (FORT et al., 2001). Sua presença também foi mostrada em tecidos placentários, onde baixos níveis de expressão gênica correlacionavam-se a perdas fetais. Estes estudos pressupuseram que a IL-25 atuava de forma protetora durante a gestação (GIANNUBILO et al., 2011; WANG et al., 2014). Baseado na possível importância estratégica dessa possibilidade para a manutenção e sucesso da gestação, neste analisamos a expressão temporal dessa citocina, a IL-25, e seu receptor IL-17BR nos compartimentos materno e fetal da placenta e no sangue materno, no modelo murino.

Nossa hipótese inicial era de que a presença de IL-25 durante a fase peri-implantacional poderia agir como fator modulador, contrabalançando possíveis desvios ou mesmo mantendo dentro da normalidade o perfil inflamatório, característico e essencial dessa etapa da gestação. Evidências mostram que durante o processo de implantação embrionária, predominam citocinas de caráter pró-inflamatório, tais como LIF, IL-1, IFN- $\gamma$, TNF- $\alpha$ e seus receptores específicos, desempenhando papeis cruciais na regulação da expressão de moléculas reguladoras e sinalizadoras (CHAOUAT et al., 2007; CHALLIS et al., 2009; MOR et al., 2011; RAGHUPATHY et al., 2008).

Nossos resultados, entretanto, mostraram que embora detectável, a expressão gênica de IL-25 nos sítios de implantação entre os dias 5,5 e 7,5 de gestação era relativamente baixa. Estes resultados também mostraram um aumento relevante da citocina na fase de placentação também analisada, o dia 10,5 de gestação.

Dada a necessidade de manutenção de um perfil pró-inflamatório na interface materno fetal (BASAK et al., 2002; DEKEL et al., 2010) para que os mecanismos relacionados a implantação do embrião no endométrio se estabeleçam adequadamente, é possível, em condições fisiológicas essa citocinas seja, de fato, mantida a níveis basais. O delineamento experimental desse estudo não incluiu ensaios inflamatórios que pudessem confirmar ou não essa possibilidade. 
Análises posteriores mostraram que havia um aumento nos níveis de expressão da IL-25 principalmente entre os dias 10,5 e 16,5 da gestação. Este aumento na expressão de IL-25 na segunda semana de gestação em camundongos, corresponde analogamente ao segundo trimestre em humanos (MALASSINE; FRENDO; EVAIN-BRION, 2003), período relacionado à maturação dos componentes placentários e formação de um ambiente imunologicamente tolerante na interface materno-fetal. Estas alterações envolvem a aquisição de um perfil anti-inflamatório do tipo Th2, tais como a IL-4, IL-5 e IL-13, a expressão de moléculas imunossupressoras e no predomínio da expressão de citocinas reguladoras (como por exemplo a IL-10) (PICCINNI et al., 2007; SAITO et al., 2007). Neste contexto, a expressão de IL-25, capaz de promover o desenvolvimento de respostas do tipo Th2 e atividades tolerogênicas, pode ter papel chave na manutenção da gestação, nesta fase gestacional (ANGKASEKWINAl et al., 2007; FORT et al., 2001; WANG et al., 2014).

A Interleucina 25 desencadeia respostas celulares mediadas por sua ligação com o complexo heterodimérico composto dos receptores IL-17AR e IL-17BR. Embora, a presença de ambos receptores seja necessária para que ocorra a sinalização da citocina, a IL-25 se liga especificamente apenas ao receptor IL-17BR (LEE et al., 2001; RICKEL et al., 2008). Para avaliar o potencial responsivo da IL-25 na interface materno fetal, analisamos também a expressão gênica dos receptores IL-17AR e IL-17BR nos tecidos placentários.

Nossos resultados mostraram níveis gênicos de IL-17AR e IL-17BR em toda a fase da gestação estudada. Estes achados sugerem a possibilidade de expressões protéicas desses receptores e portanto, a disponibilidade das unidades do complexo receptor por parte de células presentes na interface materno-fetal, que desta forma, poderiam ser responsivas a IL-25. Tanto na região fetal como na materna da placenta, níveis expressivos dos receptores foram encontrados no dia 13,5 e 16,5 de gestação. Até onde pudemos avaliar, a possível responsividade de células da interface materno-fetal a IL-25 é um dado inovador que não havia ainda sido descrito, embora a presença de IL-25 ser tópico de relevância clínica associada a abortos recorrentes (GIANNUBILO et al., 2011; WANG et al., 2014).

A produção de citocinas moduladoras depende fundamentalmente, mas não exclusivamente, de linfócitos Th2 ativados. Para avaliar que compartimentos e tipos celulares da interface estavam expressando a citocina IL-25 e seu receptor IL-17BR, 
os estudos prosseguiram com análises imunohistoquímicas e de citometria de fluxo. Sendo a ligação de IL-25 com afinidade específica ao IL-17BR, as análises protéicas avaliaram apenas essa unidade do complexo receptor nos demais estudos realizados.

Muitas das células da interface materno-fetal foram já descritas como ativas parceiras produtoras de fatores imunológicos. Estes fatores participam dos processos imunorreguladores que permitem o sucesso para a manutenção de um embrião semi ou eventualmente totalmente alogênico (barriga de aluguel) no estroma endometrial. Particularmente células trofoblásticas e deciduais participam desse mecanismo regulador, produzindo citocinas de diferentes perfis (DUDLEY et al., 1992; DAS et al., 2002; SAITO et al., 2000; SCHJENKEN et al., 2012).

A imunolocalização de IL-25 e do receptor IL-17BR mostrou diferentes populações celulares reativas, com variações temporais, na interface materno-fetal. A reatividade a citocina foi mais forte e flagrante na região fetal da placenta. No dia 10,5 de gestação praticamente todas as células trofoblásticas da placenta em formação foram reativas: células gigantes, células do labirinto e células do espongiotrofoblasto. $\mathrm{Na}$ medida em que a gestação progredia, claramente a expressão se restringiu ao labirinto e células gigantes da camada juncional. Pode não se coincidência, que estas populações celulares ocupam posições estratégicas, em contato direto com o sangue materno. Se esta é uma forma de liberar a citocina na circulação materna para atingir o sistema linfóide materno e suas respostas tolerogênica é uma questão que permanece aberta, mas que merece estudos futuros. Células trofoblásticas expressam um número muito grande de citocinas e são capazes de responder a inúmeros estímulos imunológicos (DAS et al., 2002; HOSHIDA et al., 2007; ZENCLUSSEN et al., 2013); a produção de IL-25, poderia desta forma, ser mais uma contribuição desta população celular a processos imunorreguladores da gestação.

Diferentemente da presença da citocina e dos níveis gênicos observados, a imunolocalização do receptor IL-17BR na placenta fetal, foi fraca e restrita a poucas células gigantes da zona juncional. Uma possível atividade responsiva, entretanto, não pode ser descartada, induzindo as células trofoblásticas a produzir por exemplo moléculas de atividade anti-inflamatória (GNIESINGER et al., 2001; YOUNG et al., 2002) 
Na região materna da placenta, na decídua, a expressão da citocina IL-25 foi bastante baixa em todos os dias da gestação. A citocina foi imunolocalizada em células deciduais, células estromais e leucócitos (intra e extra-vasculares) da região da glândula metrial. Ao contrário, a presença do receptor foi marcante nas células deciduais, estromais e leucocitárias da glândula metrial.

Nitidamente, o compartimento comprometido com a produção da citocina parece ser o fetal, por meio das populações de células trofoblásticas, enquanto que o responsivo parece estar contido principalmente na porção materna da placenta, sugerindo uma correlação temporal e funcionalmente parácrina entre trofoblasto e componentes celulares uterinos (células deciduais, estromais e leucocitárias).

Nossos dados de citometria de fluxo comprovaram que as células trofoblásticas, caracterizadas fenotipicamente pela presença de citoqueratina 8 $(\mathrm{CK}+)$, participam de forma mais acentuada do contingente celular que expressa IL-25 no ambiente fetal da placenta. Leucócitos (CD45+) presentes na região de trocas placentárias também participam, mas o número de células expressando o receptor IL-17BR foi muito menor.

Ainda na porção fetal da placenta, a citometria também reforçou os altos níveis de expressão do receptor, o que não foi observado nas reações imunohistoquímicas. Dada a magnitude das medidas efetuadas pela citometria de fluxo, esperávamos uma marcação tecidual mais acentuada. Quando testadas as subpopulações envolvidas nessa resposta, observamos que de fato, a grande maioria das células que expressavam o receptor pertenciam a população de células CD45+e, portanto, leucócitos. Muito possivelmente, estes leucócitos pertenciam em grande parte ao organismo materno, coletados juntamente com as demais estruturas da porção fetal da placenta, na medida em que percorriam os seios labirínticos. Neste contexto, é possível que o processamento histológico das amostras, possa ter eliminado muitas destas células não aderidas aos tecidos, minimizando a presença de células reativas nos preparados histológicos.

$\mathrm{Na}$ porção materna da placenta, os resultados da citometria também enfatizaram a possibilidade dessa região ser altamente responsiva a IL-25, principalmente no contingente de CD45+. Embora em camundongos, não se observe um infiltrado leucocitário no estroma uterino, como ocorre em humanos, já foi 
mostrada a predominante presença de células NK uterinas, além de outros leucócitos de ação imunorreguladora e importância biológica para a gestação que poderiam atuar como potenciais alvos para IL-25 mediada pela interação com o receptor IL-17BR (CHAOUAT; LEDÉE-BATAILLE; DUBANCHET, 2007; PAFFARO et al., 2003; ZENCLUSSEN et al., 2006;).

A decídua mesometrial ou basal é o componente materno da interface materno-fetal e tem papel crucial na modulação imunológica do microambiente placentário. Esta estrutura inicia sua regressão a partir do $12^{\circ}$ dia de gestação, de modo que esse território passa a ser gradativamente ocupado por um estroma de propriedades especiais em continuidade com a glândula metrial (a extremidade mais distal da câmara de implantação) e que contém uma ampla gama de células imunológicas (CROY et al., 2013). Os elevados níveis de IL-17BR nestas regiões sugerem uma ação local por meio da interação IL-25/IL-17BR, e acima de tudo uma função relevante para a gestação.

A produção de IL-25 pela interface materno-fetal, particularmente por células em contato com o sangue materno, sugere que esta citocina pode também estar sendo secretada para uma atividade periférica no organismo materno. Uma possibilidade ainda poderia ser a sensibilização de leucócitos circulantes que, em consequência, poderiam alterar a resposta imunológica nos sítios linfóides.

Para testar essa possibilidade, avaliou--se a expressão proteica do receptor IL-17BR e da citocina IL-25 nas células mononucleares sanguíneas maternas durante a gestação. Estes resultados mostraram que um baixo número de células IL-25 positivas, ao contrário do contingente de células IL-17BR+ que foi muito maior, principalmente no 16,5 dia de gestação, sugerindo que a produção de IL-25 na interface materno-fetal pode estar também atuando sobre os leucócitos maternos IL-17BR+ e desencadeando respostas periféricas.

Interessantemente, a expressão de IL-17BR na interface também se apresenta mais elevada no dia 16,5 de gestação, o que parece indicar uma pungente necessidade de respostas mediadas por esse receptor tanto no organismo materno como no fetal, nesse período gestacional (Figura 15). 


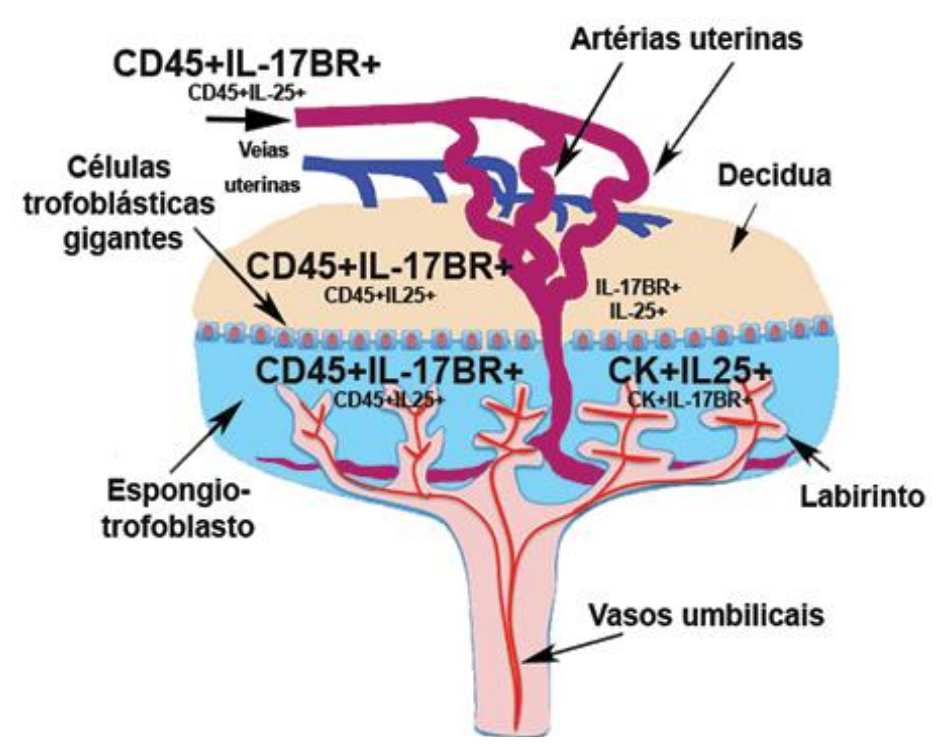

Figura 15 - Representação esquemática da participação de IL-25 e IL-17BR na placenta de camundongo.Prevalência (letras maiores) de IL-25 e IL-17BR estão representados nos diferentes compartimentos da interface materno-fetal. Adaptado de Shetty et al. (2016)

Nesta fase a placenta atinge seu grau máximo de maturação e, em cerca de $48 \mathrm{~h}$ iniciará a expressão de um perfil pró-inflamatório associado à preparação para o parto (CHRISTIAENS et al., 2008). É dessa forma possível, que a baixa expressão da interleucina 25 e seu receptor na interface materno-fetal no 19,5 dia de gestação esteja associada a esse retorno ao perfil inflamatório, aonde novamente os níveis observados são apenas basais.

Alguns mecanismos em que a citocina IL-25 está envolvida parece ser de fundamental importância para explicar a produção dessa citocina e de células potencialmente responsivas em nossos achados. Em humanos, a expressão de IL-25 é consideravelmente baixa em células do estroma endometrial de mulheres que sofrem abortos recorrentes, sugerindo um papel fundamental na gestação. Os autores discutiram a participação de IL-25 juntamente com TGF- $\beta 3$ para a manutenção de um perfil anti-inflamatório capaz de sustentar a gestação em fases críticas (GIANNUBILO et al., 2012). Lembrando que a produção de IL-25 por células Th2 está fortemente relacionada à produção de IL-4, IL-5 e IL-13, mediada pela ativação de p38, MAPK e NF-Kb (WONG et al., 2007).

Outro ângulo destes achados é a possibilidade da produção de IL-25 no ambiente placentário pode estar associada à produção de IL-9. Recentemente foram descritas novas células T auxiliadoras identificadas como Th9. Esses linfócitos estão 
envolvidos com a produção de IL-9, uma interleucina relacionada aos processos de diferenciação e proliferação de células Th2, e coopera com a IL-4 em mecanismos de regulação da síntese de anticorpos. A expressão do receptor IL-17BR foi demonstrado em células Th9, as quais, sob o estímulo de IL-25 produzem a citocina IL-9 (GOSWAMI et al., 2011; HABBEDDINE et al., 2014). A atuação de IL-25 sobre IL-9 na interface materno-fetal é especulativa, porém a partir dos alvos de IL-9 que incluem mastócitos, células Treg, células Th17 e células apresentadoras de antígeno (APCs), esta citocina pode estar atuando sobre as células Treg estimulando suas funções supressoras e sobre células apresentadoras de antígeno induzindo a produção de TGF- $\beta$, evitando assim a ativação do sistema imunológico materno contra o feto.

Além de suas funções imunes, a IL-25 parece atuar também em outros mecanismos celulares. Recentemente o trabalho de Wang e colaboradores (2014) mostrou que durante a gestação em humanos, a secreção de gonadotrofina coriônica pelo trofoblasto pode regular a expressão de IL-25/IL-17BR em células deciduais, que autocrinamente são induzidas a proliferar por meio da ativação da via JNK e AKT. A expressão de citocina na porção fetal da placenta e a imunolocalização de IL-25 nas células trofoblásticas neste estudo, assim como os níveis protéicos de IL-17BR predominante nas células da região decidual, sugerem uma possível relação também na gestação em camundongos, embora em roedores os hormônios gestacionais incluem glicoproteínas semelhantes a prolactina, e não gonadotrofina coriônica. Neste contexto a expressão da IL-25 pode representar também uma das estratégias da gestação para a regulação da atividade trofoblástica.

Esses achados reforçam a idéia de que IL-25 desempenha função moduladora na resposta imunológica durante a gestação. Embora nenhum experimento funcional tenha sido realizado neste estudo, é tentador especular que a presença da citocina e seu receptor em fases específicas da gestação, nos compartimentos que interligam os organismos materno e fetal, torna este estudo um dos grandes desafios para a compreensão dos mecanismos regulatórios gestacionais. Neste estudo, mostramos diferenças temporais e espaciais da expressão gênica e protéica da citocina IL-25 e seus receptores (principalmente o receptor IL-17RB) na interface materno fetal durante a gestação, sugerindo uma correlação funcionalmente parácrina entre trofoblasto - endométrio - leucócitos maternos, e assim introduzimos o 
questionamento de seu papel na modulação imunológica do ambiente uterino e tolerância materna. 
7 CONCLUSÕES 
Os resultados obtidos nesse trabalho nos permitem concluir que:

1. A interleucina IL-25 e seu receptor específico IL-17BR são expressos na interface materno-fetal, em diferentes níveis de acordo com o período gestacional nos diferentes compartimentos que integram a interface materno-fetal.

2. A expressão da IL-25 é mais intensa entre os dias 13,5 e 16,5 de gestação, período gestacional com predomínio de produção de citocinas anti-inflamatórias na interface materno-fetal, possivelmente atuando para o estabelecimento desse perfil.

3. Na porção fetal da placenta observa-se maior expressão proteica de IL-25 em relação ao seu receptor, sendo as células trofoblásticas importantes produtoras da citocina no ambiente placentário.

4. Na região materna, houve maior número de células (leucócitos e células deciduais) expressando o receptor IL-17BR e, portanto, um maior contingente de células potencialmente responsivas a IL-25.

5. A maior expressão de IL-25 pela porção fetal e de IL-17BR pela porção materna da placenta sugere uma ação local e uma interação parácrina entre trofoblasto e decídua.

6. O aumento de expressão principalmente de IL-17BR em leucócitos mononucleares maternos nas fases em que há aumento de expressão da IL-25 pela placenta corrobora a idéia de que esta citocina possa estar também participando da modulação destas células e consequentemente do sistema imunológico materno durante a gestação.

7. No contexto imunológico, o momento gestacional em que a IL-25 é identificada nos compartimentos da interface materno-fetal associada ao seu papel regulador, sugere que ela possa estar atuando na modulação da resposta imune local e materna, promovendo um ambiente tolerante para o desenvolvimento fetal. 


\section{REFERÊNCIAS*}

ABRAHAMSOHN, Paulo A. Ultrastructural study of the mouse antimesometrial decidua. Anatomy and embryology, v. 166, n. 2, p. 263-274, 1983.

ABRAHAMSOHN, Paulo A.; ZORN, Telma MT. Implantation and decidualization in rodents. Journal of Experimental Zoology, v. 266, n. 6, p. 603-628, 1993.

ADAMSON, S. Lee et al. Interactions between trophoblast cells and the maternal and fetal circulation in the mouse placenta. Developmental biology, v. 250, n. 2, p. 358-373, 2002.

AIN, Rupasri; CANHAM, Lindsey N.; SOARES, Michael J. Gestation stage-dependent intrauterine trophoblast cell invasion in the rat and mouse: novel endocrine phenotype and regulation. Developmental biology, v. 260, n. 1, p. 176-190, 2003.

ALUVIHARE, Varuna R.; KALLIKOURDIS, Marinos; BETZ, Alexander G. Regulatory T cells mediate maternal tolerance to the fetus. Nature immunology, v. 5, n. 3, p. 266-271, 2004.

ANGKASEKWINAI, Pornpimon et al. Interleukin 25 promotes the initiation of proallergic type 2 responses. The Journal of experimental medicine, v. 204, n. 7, p. 1509-1517, 2007.

ANGKASEKWINAI, Pornpimon et al. Regulation of IL-9 expression by IL-25 signaling. Nature immunology, v. 11, n. 3, p. 250-256, 2010.

BASAK, SAYANTANI et al. Expression of Pro-inflammatory Cytokines in Mouse Blastocysts During Implantation: Modulation by Steroid Hormones. American Journal of Reproductive Immunology, v. 47, n. 1, p. 2-11, 2002.

BAUER, M. K. et al. Fetal growth and placental function. Molecular and cellular endocrinology, v. 140, n. 1, p. 115-120, 1998.

BEVILACQUA, MARIS, Estela; A. F.; ABRAHAMSOHN, P. A. Ultrastructure of trophoblast giant cell transformation during the invasive stage of implantation of the mouse embryo. Journal of morphology, v. 198, n. 3, p. 341-351, 1988

BEVILACQUA, E. M. A. F.; ABRAHAMSOHN, P. A. Invasiveness of mouse trophoblastic cells in connective tissue. Cells Tissues Organs, v. 150, n. 4, p. 246-252, 1994.

BEVILACQUA, Estela et al. Trophoblast phagocytic program: roles in different placental systems. International Journal of Developmental Biology, v. 54, n. 2-3, p. 495-505, 2009.

BEVILACQUA, Estela et al. Ectoplacental Cone Isolation, Culture and Assessment. The Guide to Investigation of Mouse Pregnancy, p. 505-528, 2014.

*De acordo com: ASSOCIAÇÃO BRASILEIRA DE NORMAS TÉCNICAS. NBR6023: informação e documentação: referências: elaboração. Rio de Janeiro, 2002 
BLANK, Christian; GAJEWSKI, Thomas F.; MACKENSEN, Andreas. Interaction of PD-L1 on tumor cells with PD-1 on tumor-specific T cells as a mechanism of immune evasion: implications for tumor immunotherapy. Cancer Immunology, Immunotherapy, v. 54, n. 4, p. 307-314, 2005.

CHA, Jeeyeon; SUN, Xiaofei; DEY, Sudhansu K. Mechanisms of implantation: strategies for successful pregnancy. Nature Medicine, v. 18, n. 12, p. 1754-1767, 2012

CHALLIS, John R. et al. Inflammation and pregnancy. Reproductive Sciences, v. 16, n. 2, p. 206-215, 2009.

CHAOUAT, Gerard et al. Reproductive immunology 2003: reassessing the Th1/Th2 paradigm?. Immunology Letters, v. 92, n. 3, p. 207-214, 2004.

CHAOUAT, Gérard; DUBANCHET, Sylvie; LEDÉE, Nathalie. Cytokines: Important for implantation?. Journal of Assisted Reproduction and Genetics, v. 24, n. 11, p. 491-505, 2007.

CHAOUAT, Gérard; LEDÉE-BATAILLE, Nathalie; DUBANCHET, Sylvie. Immune cells in uteroplacental tissues throughout pregnancy: a brief review. Reproductive Biomedicine Online, v. 14, n. 2, p. 256-266, 2007. Disponível em: http://www.sciencedirect.com/science/article/pii/S1472648310607961 Acessado em: Set. 2016.

CHRISTIAENS, Inge et al. Inflammatory processes in preterm and term parturition. Journal of Reproductive Immunology, v. 79, n. 1, p. 50-57, 2008.

CROSS, James C.; WERB, Zena; FISHER, Susan J. Implantation and the placenta: key pieces of the development puzzle. Science, v. 266, n. 5190, p. 1508, 1994.

CROSS, James C. et al. Trophoblast functions, angiogenesis and remodeling of the maternal vasculature in the placenta. Molecular and Cellular Endocrinology, v. 187, n. 1, p. 207-212, 2002.

CROSS, J. C. How to make a placenta: mechanisms of trophoblast cell differentiation in mice-a review. Placenta, v. 26, p. S3-S9, 2005.

CROSS, James C. Placental function in development and disease. Reproduction, Fertility and Development, v. 18, n. 2, p. 71-76, 2005.

CROY, B. Anne et al. (Ed.). The Guide To Investigation of Mouse Pregnancy. Academic Press, 2013.

DAS, Chandana et al. Network of cytokines, integrins and hormones in human trophoblast cells. Journal of Reproductive Immunology, v. 53, n. 1, p. 257-268, 2002.

DARMOCHWAL-KOLARZ, Dorota et al. The predominance of Th17 lymphocytes and decreased number and function of Treg cells in preeclampsia. Journal of Reproductive Immunology, v. 93, n. 2, p. 75-81, 2012. 
DEKEL, Nava et al. Review article: inflammation and implantation. American Journal of Reproductive Immunology, v. 63, n. 1, p. 17-21, 2010.

DUDLEY, DONALD J. et al. Decidual cell biosynthesis of interleukin-6: regulation by inflammatory cytokines. The Journal of Clinical Endocrinology \& Metabolism, v. 74, n. 4, p. 884-889, 1992.

DYCE, Jonathan et al. Do trophectoderm and inner cell mass cells in the mouse blastocyst maintain discrete lineages?. Development, v. 100, n. 4, p. 685-698, 1987.

ENDERS, Allen C. A comparative study of the fine structure of the trophoblast in several hemochorial placentas. American Journal of Anatomy, v. 116, n. 1, p. 29-67, 1965.

ENDERS, A. C.; SCHLAFKE, S. Comparative aspects of blastocyst-endometrial interactions at implantation. Maternal Recognition of Pregnancy, n. 64, p. 3, 1979.

ENTRICAN, G. Immune regulation during pregnancy and host-pathogen interactions in infectious abortion. Journal of Comparative Pathology, v. 126, n. 2, p. 79-94, 2002.

ERLEBACHER, Adrian. Immunology of the maternal-fetal interface. Annual Review of Immunology, v. 31, p. 387-411, 2013CHA

FORT, Madeline M. et al. IL-25 induces IL-4, IL-5, and IL-13 and Th2-associated pathologies in vivo. Immunity, v. 15, n. 6, p. 985-995, 2001.

GIANNUBILO, Stefano R. et al. 710: Inflammatory cytokines pattern in recurrent miscarriage. American Journal of Obstetrics and Gynecology, v. 204, n. 1, p. S280, 2011.

GNIESINGER, Georg et al. Production of pro-and anti-inflammatory cytokines of human placental trophoblasts in response to pathogenic bacteria. Journal of the Society for Gynecologic Investigation, v. 8, n. 6, p. 334-340, 2001.

GRABAREK, Joanna B. et al. Differential plasticity of epiblast and primitive endoderm precursors within the ICM of the early mouse embryo. Development, v. 139, n. 1, p. 129-139, 2012.

GEORGIADES, P.; FERGUSON-SMITH, A. C.; BURTON, G. J. Comparative developmental anatomy of the murine and human definitive placentae. Placenta, $v$. 23, n. 1, p. 3-19, 2002.

GULERIA, Indira et al. A critical role for the programmed death ligand 1 in fetomaternal tolerance. The Journal of Experimental Medicine, v. 202, n. 2, p. 231-237, 2005.

GOSWAMI, Ritobrata; KAPLAN, Mark H. A brief history of IL-9. The Journal of Immunology, v. 186, n. 6, p. 3283-3288, 2011.

HABBEDDINE, Mohamed et al. Leukocyte population dynamics and detection of IL-9 as a major cytokine at the mouse fetal-maternal interface. PloS one, v. 9, n. 9, p. e107267, 2014. 
HEMBERGER, Myriam et al. Differential expression of angiogenic and vasodilatory factors by invasive trophoblast giant cells depending on depth of invasion. Developmental Dynamics, v. 227, n. 2, p. 185-191, 2003.

HORI, Junko et al. B7-H1-induced apoptosis as a mechanism of immune privilege of corneal allografts. The Journal of Immunology, v. 177, n. 9, p. 5928-5935, 2006.

HOSHIDA, M. S. et al. Regulation of gene expression in mouse trophoblast cells by interferon-gamma. Placenta, v. 28, n. 10, p. 1059-1072, 2007.

HU, Dong; CROSS, James C. Development and function of trophoblast giant cells in the rodent placenta. International Journal of Developmental Biology, v. 54, n. 2-3, p. 341-354, 2009.

HU, Dong; CROSS, James C. Ablation of Tpbpa-positive trophoblast precursors leads to defects in maternal spiral artery remodeling in the mouse placenta. Developmental biology, v. 358, n. 1, p. 231-239, 2011.

HURST, Stephen D. et al. New IL-17 family members promote Th1 or Th2 responses in the lung: in vivo function of the novel cytokine IL-25. The Journal of Immunology, v. 169, n. 1, p. 443-453, 2002.

JABBOUR, Henry N. et al. Inflammatory pathways in female reproductive health and disease. Reproduction, v. 138, n. 6, p. 903-919, 2009

JOHN, Rosalind; HEMBERGER, Myriam. A placenta for life. Reproductive Biomedicine Online, v. 25, n. 1, p. 5-11, 2012. Disponível em: < http://www.rbmojournal.com/article/S1472-6483(12)00206-4/pdf > Acesso em: Set. 2016.

HURST, Stephen D. et al. New IL-17 family members promote Th1 or Th2 responses in the lung: in vivo function of the novel cytokine IL-25. The Journal of Immunology, v. 169, n. 1, p. $443-453,2002$.

KATZ, Sima; ABRAHAMSOHN, P. A. Involution of the antimesometrial decidua in the mouse. Anatomy and Embryology, v. 176, n. 2, p. 251-258, 1987.

LALA, Peeyush K. et al. Immunological Role of the Cellular Constituents of the Decidua in the Maintenance of Semiallogeneic Pregnancya. Annals of the New York Academy of Sciences, v. 476, n. 1, p. 183-205, 1986.

LEE, James et al. IL-17E, a novel proinflammatory ligand for the IL-17 receptor homolog IL-17Rh1. Journal of Biological Chemistry, v. 276, n. 2, p. 1660-1664, 2001.

LEISER, R.; KAUFMANN, P. Placental structure: in a comparative aspect. Experimental and Clinical Endocrinology \& Diabetes, v. 102, n. 03, p. 122-134, 1994.

MALASSINE, A.; FRENDO, J.-L.; EVAIN-BRION, D. A comparison of placental development and endocrine functions between the human and mouse model. Human Reproduction Update, v. 9, n. 6, p. 531-539, 2003. 
MAYBIN, Jacqueline A.; CRITCHLEY, Hilary OD; JABBOUR, Henry N. Inflammatory pathways in endometrial disorders. Molecular and Cellular Endocrinology, v. 335, n. 1, p. 42-51, 2011.

MOR, Gil et al. Inflammation and pregnancy: the role of the immune system at the implantation site. Annals of the New York Academy of Sciences, v. 1221, n. 1, p. 80-87, 2011.

MOSMANN, Timothy R. et al. Two types of murine helper T cell clone. I. Definition according to profiles of lymphokine activities and secreted proteins. The Journal of Immunology, v. 136, n. 7, p. 2348-2357, 1986.

MOSMANN, Tim R.; COFFMAN, Robert L. Heterogeneity of cytokine secretion patterns and functions of helper T cells. Advances in Immunology, v. 46, p. 111-147, 1989.

MÜNTENER, M.; HSU, Y.-C. Development of trophoblast and placenta of the mouse. Cells Tissues Organs, v. 98, n. 3, p. 241-252, 1977.

NAKAYAMADA, Shingo et al. Helper T cell diversity and plasticity. Current Opinion in Immunology, v. 24, n. 3, p. 297-302, 2012.

PAFFARO, V. A. et al. Subset classification of mouse uterine natural killer cells by DBA lectin reactivity. Placenta, v. 24, n. 5, p. 479-488, 2003.

PLAISIER, Margreet. Decidualisation and angiogenesis. Best Practice \& Research Clinical Obstetrics \& Gynaecology, v. 25, n. 3, p. 259-271, 2011.

O'GARRA, Anne. Cytokines induce the development of functionally heterogeneous T helper cell subsets. Immunity, v. 8, n. 3, p. 275-283, 1998.

PETROFF, Margaret G. et al. B7 family molecules are favorably positioned at the human maternal-fetal interface. Biology of Reproduction, v. 68, n. 5, p. 1496-1504, 2003.

PETROFF, Margaret G. Immune interactions at the maternal-fetal interface. Journal of Reproductive Immunology, v. 68, n. 1, p. 1-13, 2005.

PICCINNI, M.-P. Role of T-cell cytokines in decidua and in cumulus oophorus during pregnancy. Gynecologic and Obstetric Investigation, v. 64, n. 3, p. 144-148, 2007.

RAGHUPATHY, Raj et al. Cytokine patterns in maternal blood after premature rupture of membranes. Obstetrics \& Gynecology, v. 98, n. 1, p. 122-126, 2001.

RAGHUPATHY, Raj; KALINKA, Jaroslaw. Cytokine imbalance in pregnancy complications and its modulation. Front Biosci, v. 13, n. 1, p. 985-994, 2008.

REYNOLDS, Lawrence P.; REDMER, D. A. Utero-placental vascular development and placental function. Journal of Animal Science, v. 73, n. 6, p. 1839-1851, 1995 
RICKEL, Erika A. et al. Identification of functional roles for both IL-17RB and IL-17RA in mediating IL-25-induced activities. The Journal of Immunology, v. 181, n. 6, p. 4299-4310, 2008.

ROMAGNANI, Sergio. T-cell subsets (Th1 versus Th2). Annals of Allergy, Asthma \& Immunology, v. 85, n. 1, p. 9-21, 2000.

ROSSANT, Janet; CROSS, James C. Placental development: lessons from mouse mutants. Nature Reviews Genetics, v. 2, n. 7, p. 538-548, 2001.

SAITO, Shigeru. Cytokine network at the feto-maternal interface. Journal of Reproductive Immunology, v. 47, n. 2, p. 87-103, 2000.

SAITO, Shigeru et al. What is the role of regulatory $T$ cells in the success of implantation and early pregnancy?. Journal of Assisted Reproduction and Genetics, v. 24, n. 9, p. 379-386, 2007.

SAITO, Shigeru et al. REVIEW ARTICLE: Th1/Th2/Th17 and Regulatory T-Cell Paradigm in Pregnancy. American Journal of Reproductive Immunology, v. 63, n. 6, p. 601-610, 2010.

SANGUANSERMSRI, Donruedee; PONGCHAROEN, Sutatip. Pregnancy immunology: decidual im-mune cells. Asian Pacific Journal of Allergy and Immunology, v. 26, n. 2-3, p. 171, 2008.

SANTNER-NANAN, Brigitte et al. Systemic increase in the ratio between Foxp3+ and IL-17-producing CD4+ T cells in healthy pregnancy but not in preeclampsia. The Journal of Immunology, v. 183, n. 11, p. 7023-7030, 2009.

SCHJENKEN, John E. et al. Mechanisms of Maternal Immune Tolerance During Pregnancy. INTECH Open Access Publisher, 2012.

SIMMONS, David G.; FORTIER, Amanda L.; CROSS, James C. Diverse subtypes and developmental origins of trophoblast giant cells in the mouse placenta. Developmental Biology, v. 304, n. 2, p. 567-578, 2007.

TAMACHI, Tomohiro et al. IL-25 enhances allergic airway inflammation by amplifying a $\mathrm{T} H 2$ cell-dependent pathway in mice. Journal of Allergy and Clinical Immunology, v. 118, n. 3, p. 606-614, 2006.

WANG, Chunlian et al. Granulated metrial gland cells in the murine uterus: localization, kinetics, and the functional role in angiogenesis during pregnancy. Microscopy Research and Technique, v. 60, n. 4, p. 420-429, 2003.

WANG, Haibin; DEY, Sudhansu K. Roadmap to embryo implantation: clues from mouse models. Nature Reviews Genetics, v. 7, n. 3, p. 185-199, 2006.

WANG, Ying et al. Interleukin-25 induced by human chorionic gonadotropin promotes the proliferation of decidual stromal cells by activation of JNK and AKT signal pathways. Fertility and Sterility, v. 102, n. 1, p. 257-263, 2014. 
WATSON, Erica D.; CROSS, James C. Development of structures and transport functions in the mouse placenta. Physiology, v. 20, n. 3, p. 180-193, 2005.

WANG, Wen-Juan et al. Increased prevalence of T helper 17 (Th17) cells in peripheral blood and decidua in unexplained recurrent spontaneous abortion patients. Journal of Reproductive Immunology, v. 84, n. 2, p. 164-170, 2010

WILCZYŃSKI, Jacek R. Th1/Th2 cytokines balance-yin and yang of reproductive immunology. European Journal of Obstetrics \& Gynecology and Reproductive Biology, v. 122, n. 2, p. 136-143, 2005.

WONG, Chun Kwok; LI, Pok Wai; LAM, Christopher Wai Kei. Intracellular JNK, p38 MAPK and NF-KB regulate IL-25 induced release of cytokines and chemokines from costimulated T helper lymphocytes. Immunology Letters, v. 112, n. 2, p. 82-91, 2007.

YOSHINAGA, Koji. REVIEW ARTICLE: Research on Blastocyst Implantation Essential Factors (BIEFs). American Journal of Reproductive Immunology, v. 63, n. 6, p. 413-424, 2010.

YOUNG, Anne et al. Immunolocalization of proinflammatory cytokines in myometrium, cervix, and fetal membranes during human parturition at term. Biology of Reproduction, v. 66, n. 2, p. 445-449, 2002.

YU, Hak Sun et al. Protease allergens induce the expression of IL-25 via Erk and p38 MAPK pathway. Journal of Korean Medical Science, v. 25, n. 6, p. 829-834, 2010.

ZENCLUSSEN, Ana Claudia. CD4+ CD25+ $T$ regulatory cells in murine pregnancy. Journal of Reproductive Immunology, v. 65, n. 2, p. 101-110, 2005.

ZENCLUSSEN, Ana $\mathrm{C}$. et al. Regulatory $\mathrm{T}$ cells induce a privileged tolerant microenvironment at the fetal-maternal interface. European Journal of Immunology, v. 36, n. 1, p. 82-94, 2006.

ZENCLUSSEN, Ana Claudia. Adaptive immune responses during pregnancy. American Journal of Reproductive Immunology, v. 69, n. 4, p. 291-303, 2013.

ZHANG, Shuang et al. Physiological and molecular determinants of embryo implantation. Molecular Aspects of Medicine, v. 34, n. 5, p. 939-980, 2013.

ZHOU, Liang; CHONG, Mark MW; LITTMAN, Dan R. Plasticity of CD4+ T cell lineage differentiation. Immunity, v. 30, n. 5, p. 646-655, 2009. 


\section{APÊNDICE}

\section{Apêndice A - Análise de Citometria de Fluxo na Porção Fetal da Placenta}

A)

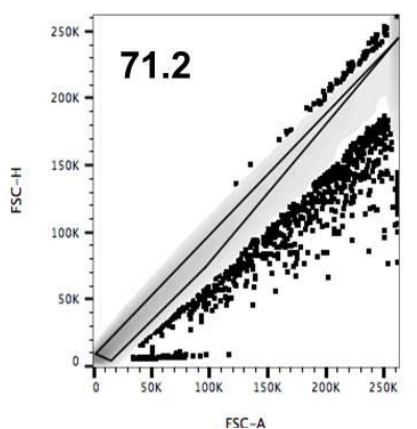

B)

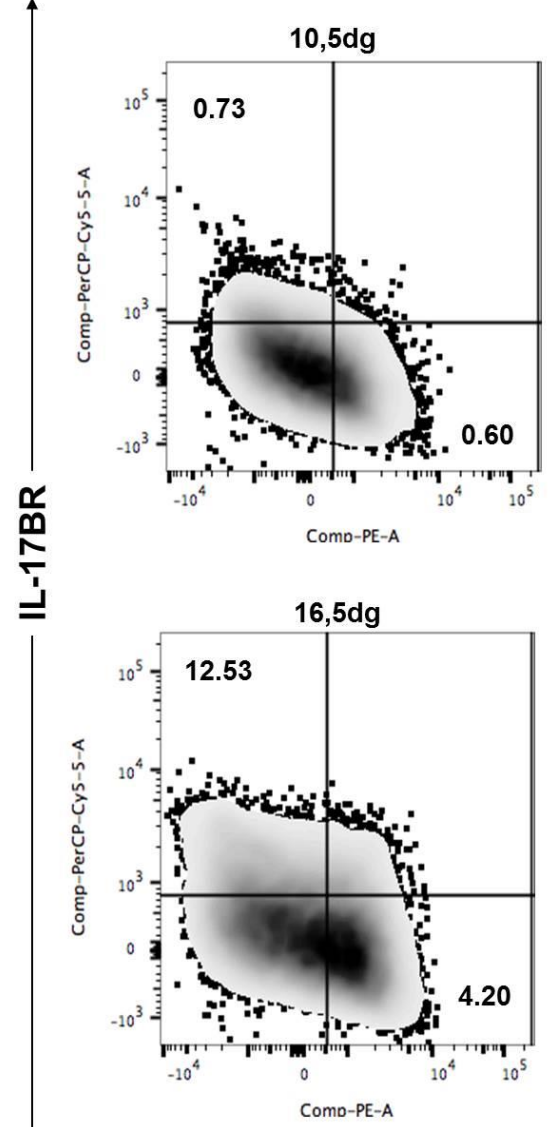

Placenta Fetal

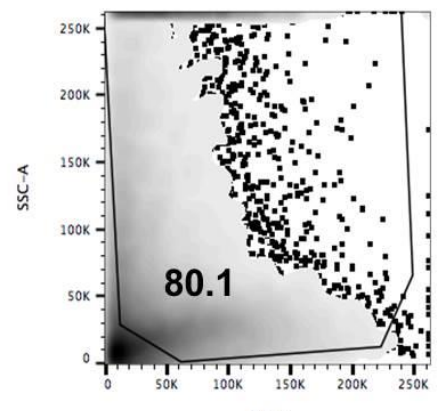

FSC-A

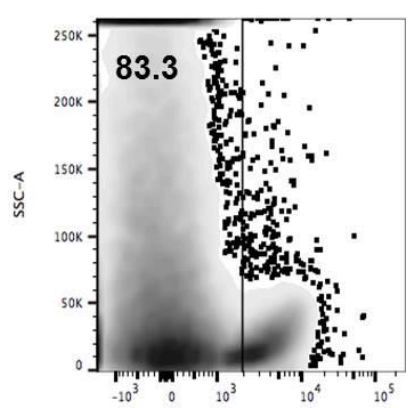

Como-AmCvan-A

Placenta Fetal
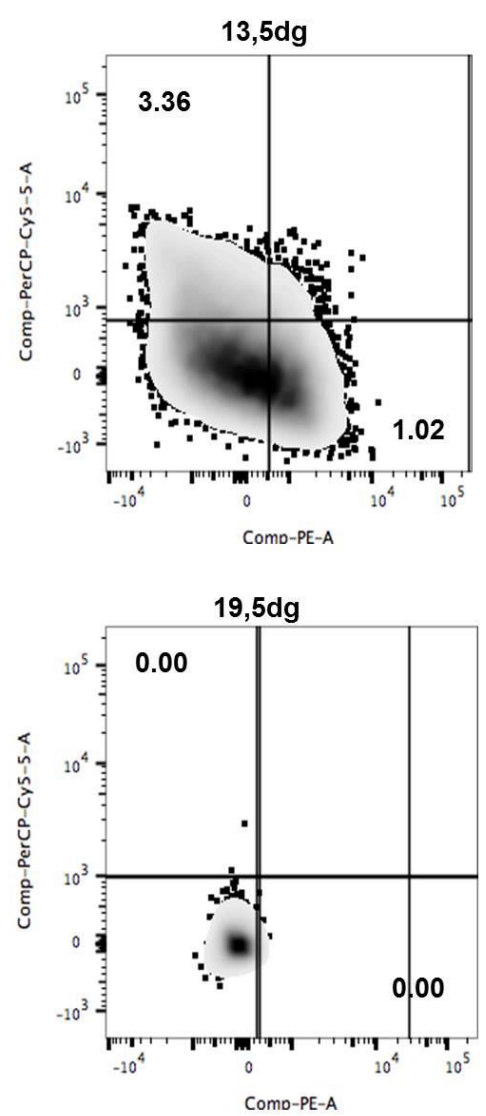

IL-25

Figura 16 - Análise por citometria de fluxo para IL-25 e IL-17BR na porção fetal da placenta: Dot plot ilustrativo da estratégia de gate utilizada para avaliar a viabilidade celular $(A)$ e a produção de IL-25 e expressão do seu receptor IL-17BR por células obtidas da placenta de camundongos no decorrer dos dias 10,5 - 19,5 de gestação (B). Valores expressos em porcentagem de células. 


\section{Apêndice B - Produção de IL-25 e IL-17BR por Células Trofoblásticas e Linfocitárias na Porção Fetal da Placenta}

A)

Placenta Fetal

IL-25+
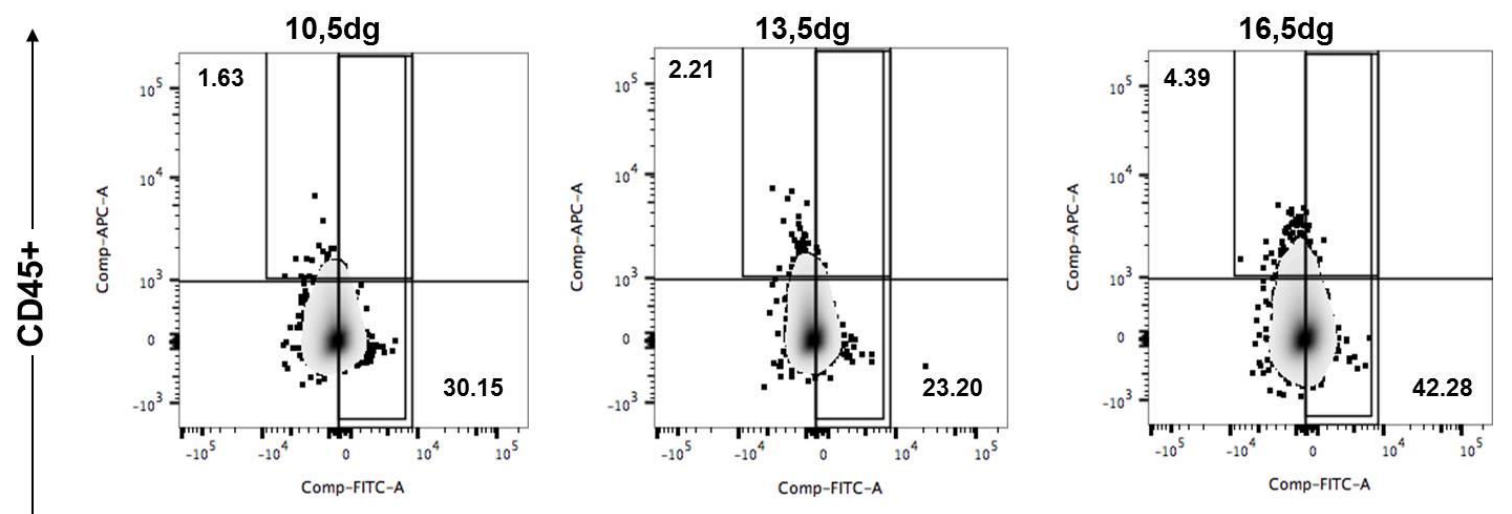

$\mathrm{CK}+$

B)

\section{Placenta Fetal}

IL-17BR+
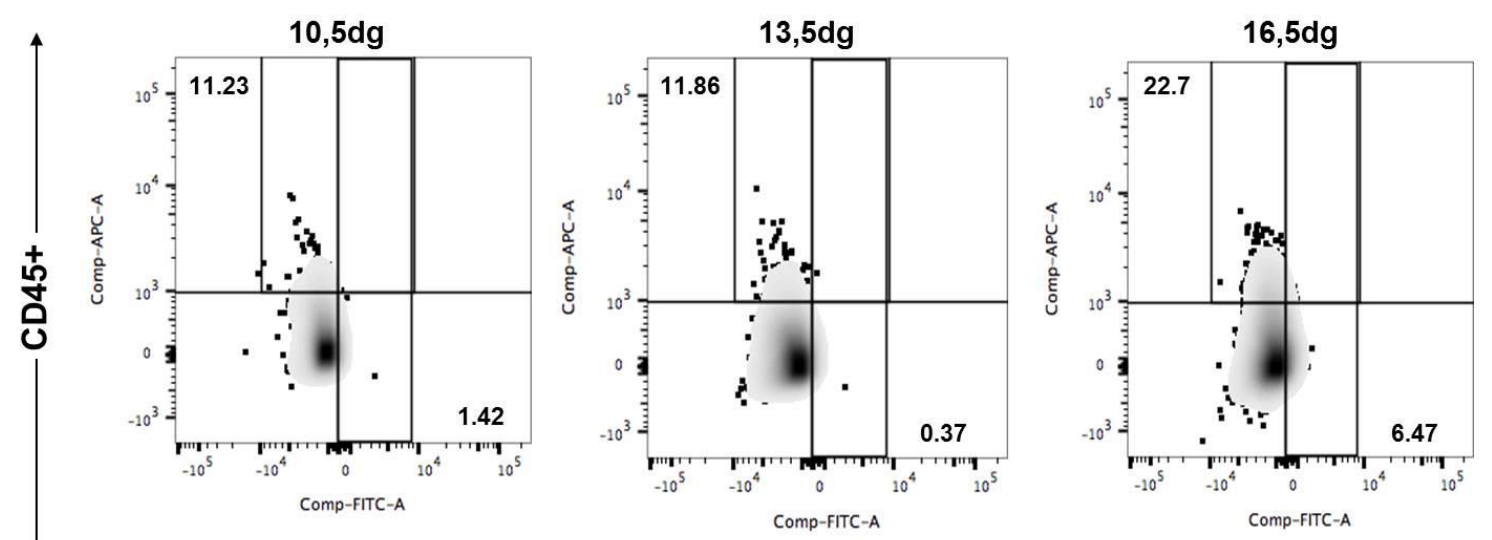

$\mathrm{CK}+$

Figura 17 - Expressão de IL-25 e seu receptor IL-17BR por células trofoblásticas e leucócitos na placenta fetal: Dot plot ilustrativo da estratégia de gate utilizada para avaliar a produção de IL-25 (A) e expressão do seu receptor (B) por células leucocitárias (CD45+) e trofoblásticas (CK+) na porção fetal da placenta de camundongos entre os dias 10,5 16,5 de gestação. Análise realizada por Citometria de Fluxo. Valores expressos em porcentagem de células. 


\section{Apêndice C - Análise de Citometria de Fluxo na Porção Materna da Placenta}

A)

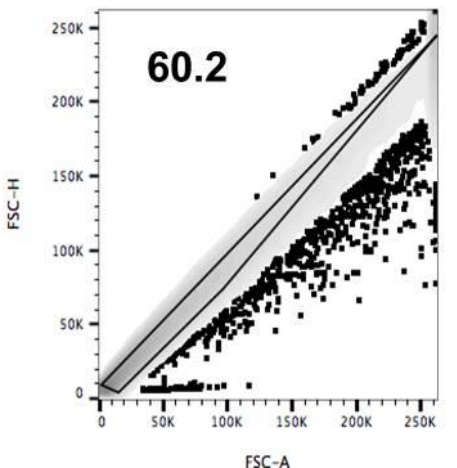

B)

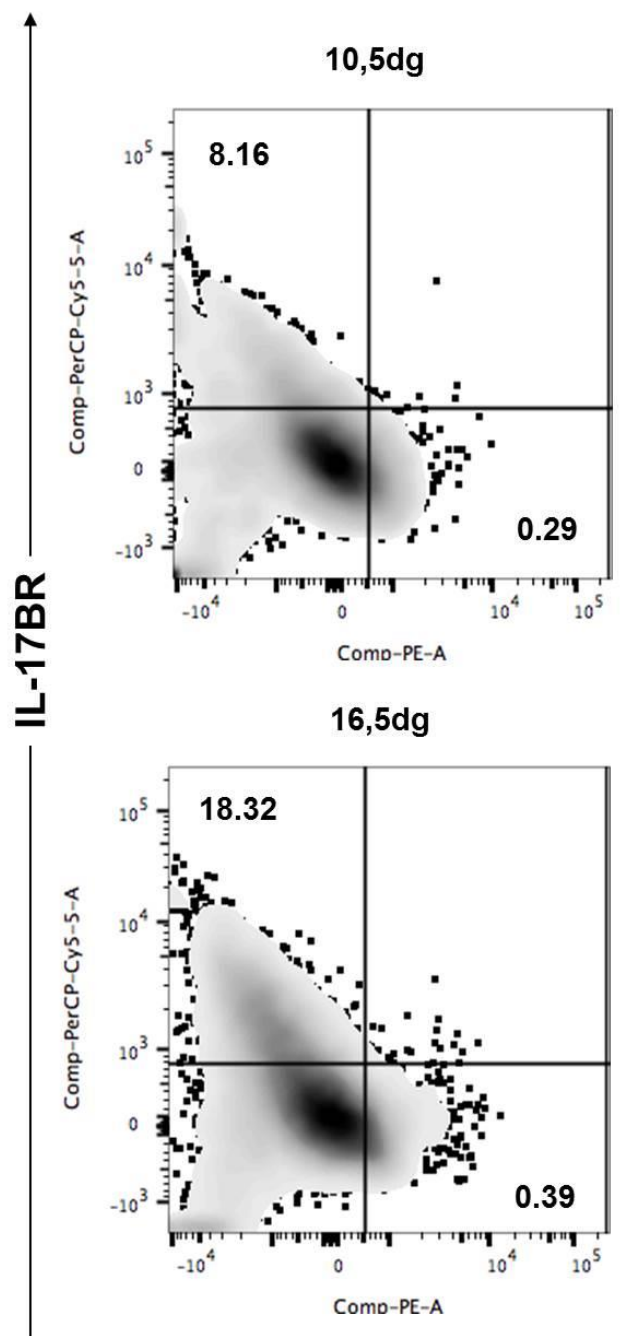

Decídua
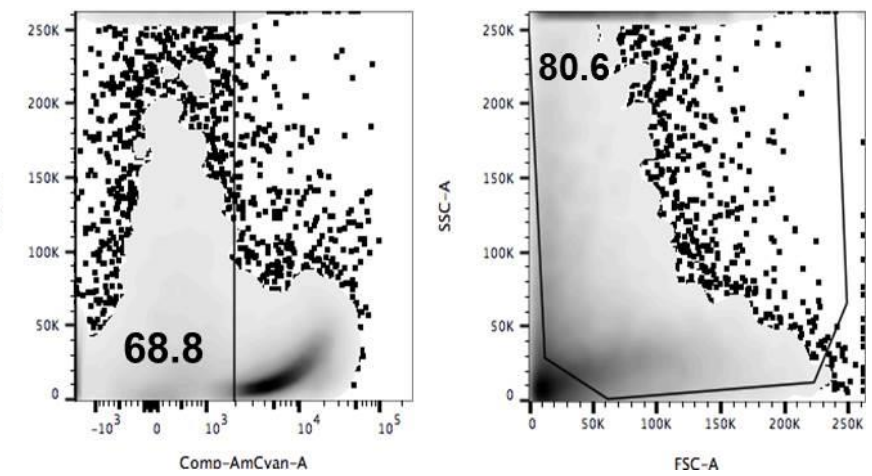

Decídua
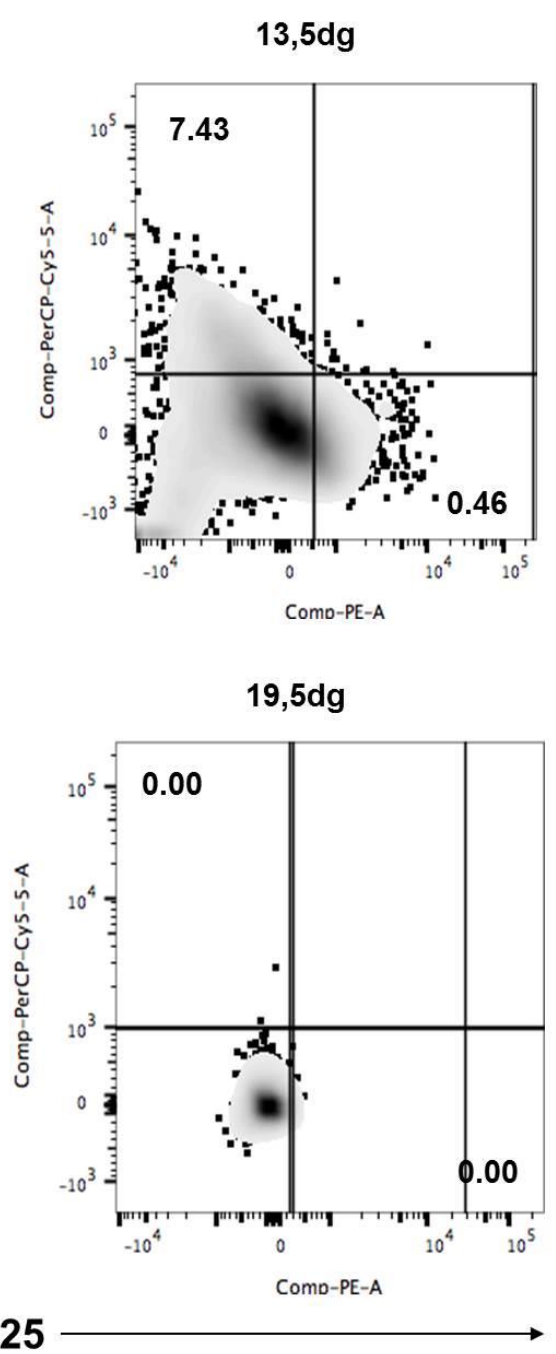

Figura 18 - Análise por citometria de fluxo para IL-25 e IL-17BR na porção materna da placenta: Dot plot ilustrativo da estratégia de gate utilizada para avaliar a viabilidade celular $(A)$ e a produção de IL-25 e expressão do seu receptor por células isoladas da decídua no decorrer dos dias de gestação (10,5dg; 13,5dg e 16,5dg) (B). Valores expressos em porcentagem de células. 


\section{Apêndice D - Produção de IL-25 e IL-17BR por Células Linfocitárias na Porção Materna da Placenta}

A)

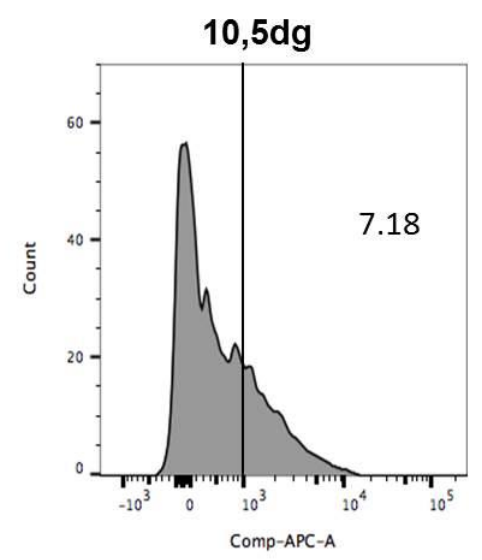

B)

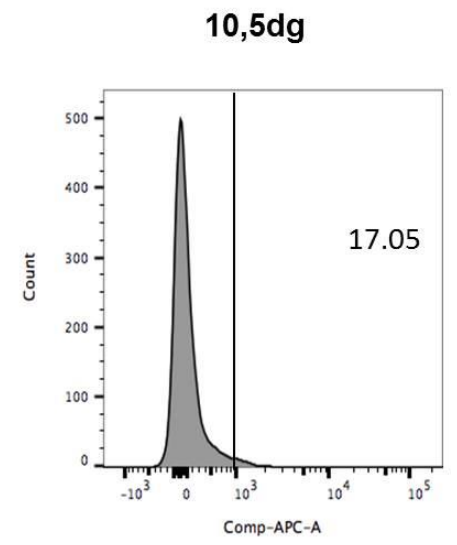

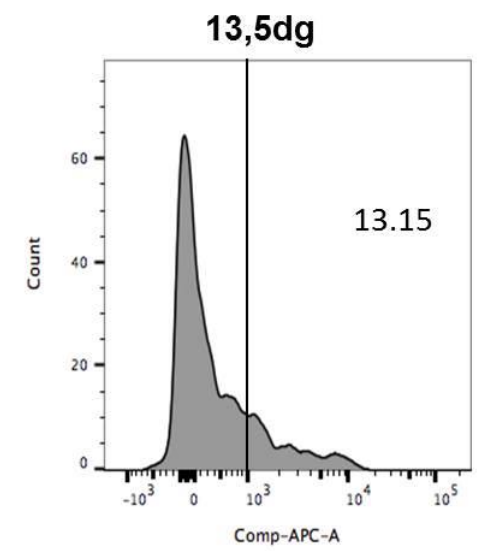

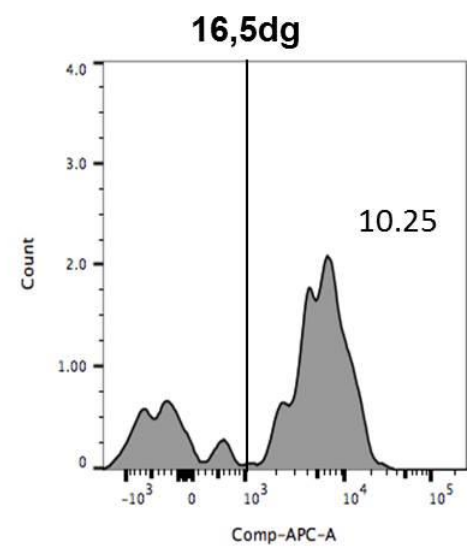

Decídua

IL-17BR+/CD45+

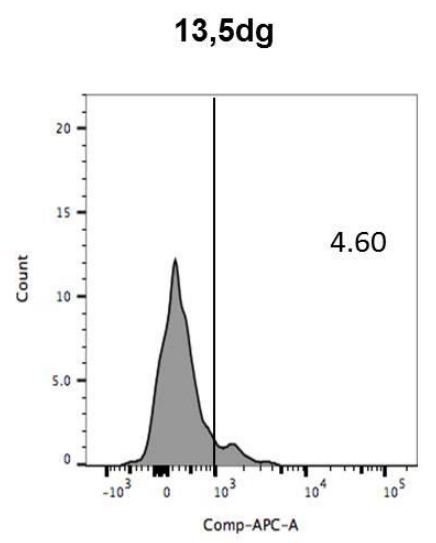

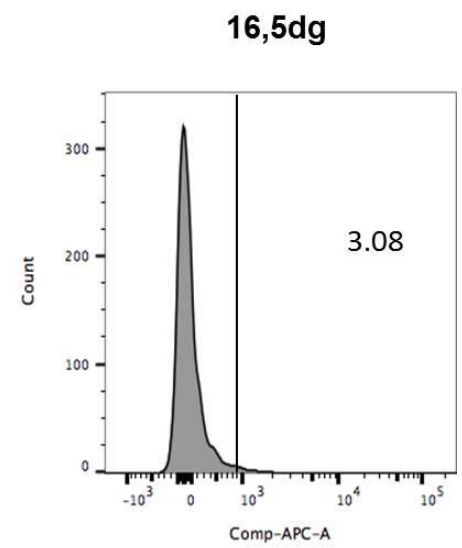

Figura 19 - Expressão de IL-25 e seu receptor IL-17BR por células leucocitárias na porção materna da placenta:Dot plot ilustrativo da estratégia de gate utilizada para avaliar a produção de IL-25 (A) e expressão do seu receptor (B) por leucócitos (CD45+) isolados da porção materna da placenta de camundongos entre os dias 10,5 - 16,5 de gestação. Análise realizada por Citometria de Fluxo. Valores expressos em porcentagem de células. 
Apêndice E - Produção de IL-25 e IL-17BR por Células Mononucleares do Sangue Periférico (CMNs) em Camundongos Fêmeas Prenhes

A)

\section{CMNs}
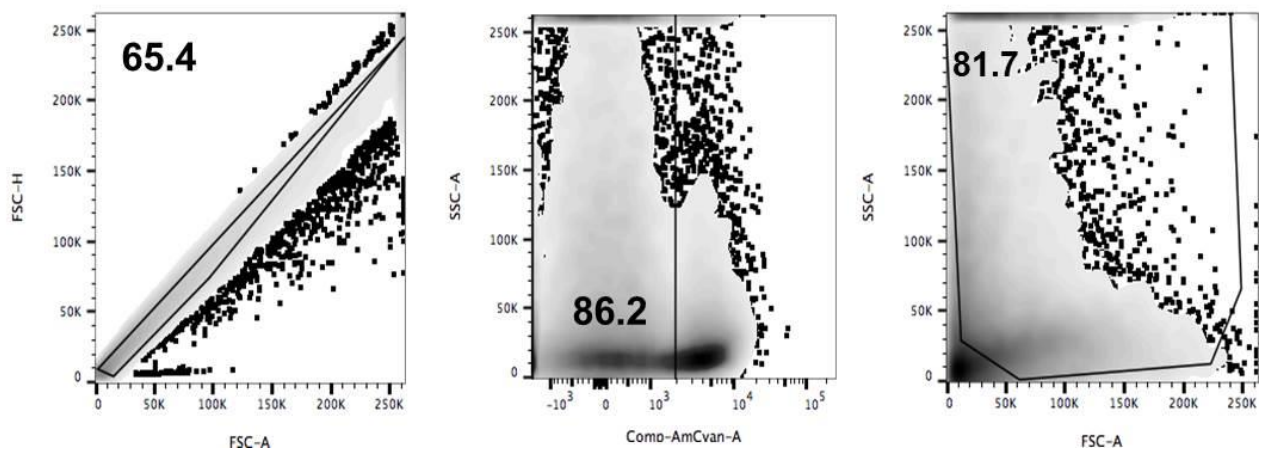

B)

\section{CMNs}
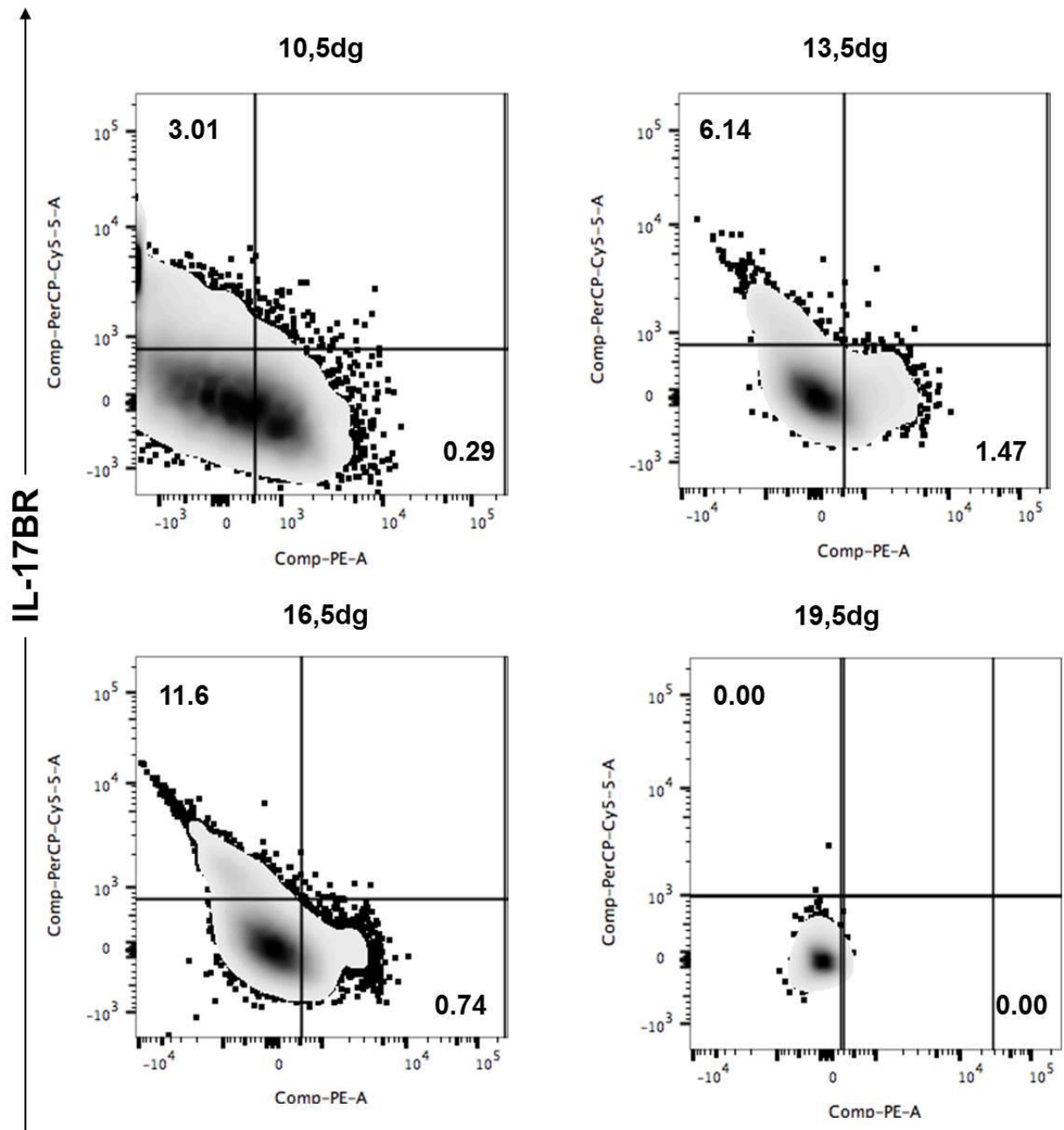

IL-25

Figura 20 - Análise por citometria de fluxo para IL-25 e IL-17BR no sangue periférico materno: Dot plot ilustrativo da estratégia de gate utilizada para avaliar a viabilidade celular $(A)$ e a produção de IL-25 e expressão do seu receptor IL-17BR por células mononucleares (CMNs) isoladas do sangue periférico de camundongos fêmeas prenhes ao 10,5, 13,5 e 16,5 dias de gestação (B). Valores expressos em porcentagem de células 